\title{
Six Common Herbs with Distinctive Bioactive, Antioxidant Components. A Review of Their Separation Techniques
}

\author{
Antigoni Oreopoulou ${ }^{1,2}$, Evanthia Choulitoudi ${ }^{1}$, Dimitrios Tsimogiannis ${ }^{1,3}$ (i) and Vassiliki Oreopoulou $1, *$ (D) \\ 1 Laboratory of Food Chemistry and Technology, School of Chemical Engineering, \\ National Technical University of Athens, 5 Iroon Polytechniou, 15780 Athens, Greece; \\ antigoni@vioryl.gr (A.O.); echoulit@chemeng.ntua.gr (E.C.); ditsimog@chemeng.ntua.gr (D.T.) \\ 2 Vioryl, Agricultural and Chemical Industry, Research S.A., 28th km National Road Athens-Lamia, \\ 19014 Attiki, Greece \\ 3 NFA (Natural Food Additives), Laboratory of Natural Extracts Development, 6 Dios st, 17778 Athens, Greece \\ * Correspondence: vasor@chemeng.ntua.gr; Tel.: +30-2107723166
}

Citation: Oreopoulou, A.; Choulitoudi, E.; Tsimogiannis, D.; Oreopoulou, V. Six Common Herbs with Distinctive Bioactive,

Antioxidant Components. A Review of Their Separation Techniques. Molecules 2021, 26, 2920. https:// doi.org/10.3390/molecules26102920

Academic Editor: Petras Rimantas Venskutonis

Received: 23 April 2021

Accepted: 10 May 2021

Published: 14 May 2021

Publisher's Note: MDPI stays neutral with regard to jurisdictional claims in published maps and institutional affiliations.

Copyright: (c) 2021 by the authors. Licensee MDPI, Basel, Switzerland. This article is an open access article distributed under the terms and conditions of the Creative Commons Attribution (CC BY) license (https:// creativecommons.org/licenses/by/ $4.0 /)$.

\begin{abstract}
Rosemary, oregano, pink savory, lemon balm, St. John's wort, and saffron are common herbs wildly grown and easily cultivated in many countries. All of them are rich in antioxidant compounds that exhibit several biological and health activities. They are commercialized as spices, traditional medicines, or raw materials for the production of essential oils. The whole herbs or the residues of their current use are potential sources for the recovery of natural antioxidant extracts. Finding effective and feasible extraction and purification methods is a major challenge for the industrial production of natural antioxidant extracts. In this respect, the present paper is an extensive literature review of the solvents and extraction methods that have been tested on these herbs. Green solvents and novel extraction methods that can be easily scaled up for industrial application are critically discussed.
\end{abstract}

Keywords: rosemary; oregano; pink savory; lemon balm; St. John's wort; saffron; extraction

\section{Introduction}

During the last decades research has focused on natural antioxidants for use in food and cosmetics because they are more appealing to consumers. Plant material have been mostly investigated as potent sources, including cereals, seeds, spices, herbs, and some agroindustrial byproducts [1]. Among them, a considerable body of research efforts has been devoted to aromatic or medicinal plants, as they have been traditionally used for culinary purposes as spices or infusions, and also for their curative properties against mild disorders. Several aromatic and medicinal plants grow wildly in the Mediterranean region and in several other regions, while they are also cultivated.

Flavonoids, phenolic acids, and phenolic diterpenes are the aromatic plant constituents mostly associated with their antioxidant properties. Other groups of compounds with bioactive properties are the phloroglucinols and the naphtodianthrones. In addition, apocarotenoid glycosides have exhibited valuable biological activities. The main structures of these compounds are presented in Figure $1 \mathrm{a}, \mathrm{b}$ and it is evident that most of them contain phenolic hydroxyl groups. Besides their antioxidant capacity, many of these compounds present antimicrobial and antiviral properties and various beneficial health effects.

The Lamiaceae family contains several genera that have been extensively studied for their antioxidant potential. Outstanding among them is rosemary that is rich in carnosic acid, carnosol, and rosmarinic acid. Other Lamiaceae herbs, rich in rosmarinic acid and various flavonoids, are oregano species, lemon balm (Melissa officinalis), and Satureja species. All of them are easily cultivated and commercialized as spices. Additionally, their essential oil (EO) is used in cosmetics, food, and feed products. EO is obtained through steamor hydrodistillation. Nevertheless, the yield of distillation is rather low, while the solid 
residue is discarded and causes environmental concerns, although it is a potent raw material for the recovery of antioxidants [2,3]. For example, rosemary yields around 0.3-2.5 g EO/100 g of dry plant [4-7], while a considerable amount of solid residue remains $\left(10-20 \times 10^{3} \mathrm{Tn} /\right.$ year) that is currently unexploited [8]. Moreover, deoiling leaves a raw material free of odors, and facilitates the phenolic compounds extraction probably due to enhanced penetration of solvent and mass transfer phenomena $[4,9]$. Therefore, this residue can be efficiently used for antioxidant extraction.

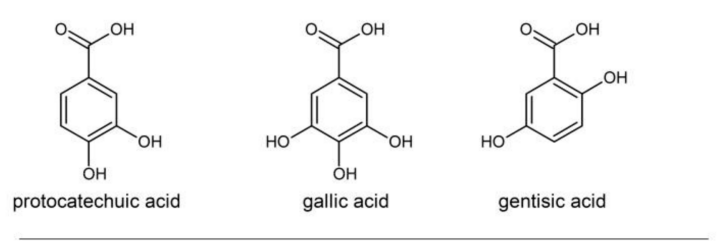

hydroxybenzoic acids<smiles>O=C(O)/C=C/c1ccc(O)cc1</smiles><smiles>O=C(/C=C/c1cccc2c1[C@@H](C(=O)O)[C@H](c1ccc(O)c(O)c1)O2)O[C@@H](Cc1ccc(O)c(O)c1)C(=O)O</smiles><smiles>O=C(/C=C/c1ccc(O)c(O)c1)OC(C(=O)O)C(OC(=O)/C=C/c1ccc(O)c(O)c1)C(=O)OC(Cc1ccc(O)c(O)c1)C(=O)OC(Cc1ccc(O)c(O)c1)C(=O)O</smiles>

hydroxycinnamic acids and derivatives

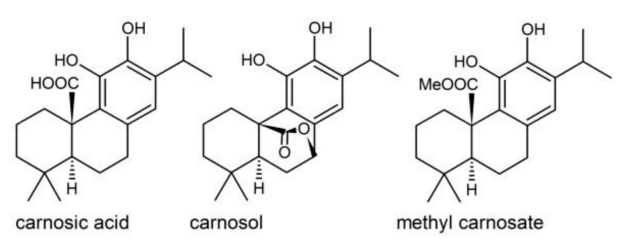

phenolic diterpenes

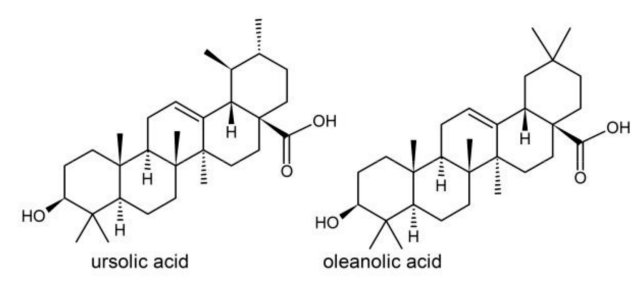

triterpenic acids

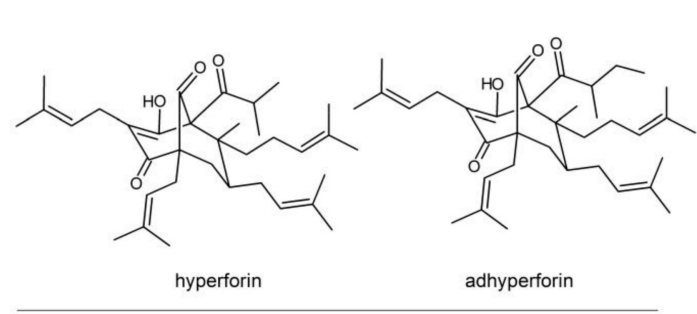

phloroglucinols (hyperforins)

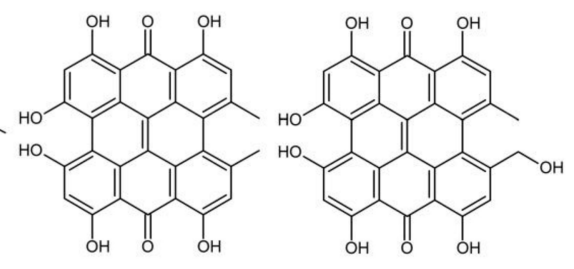

hypericin

naphthodianthrones (hypericins)

Figure 1. Cont. 

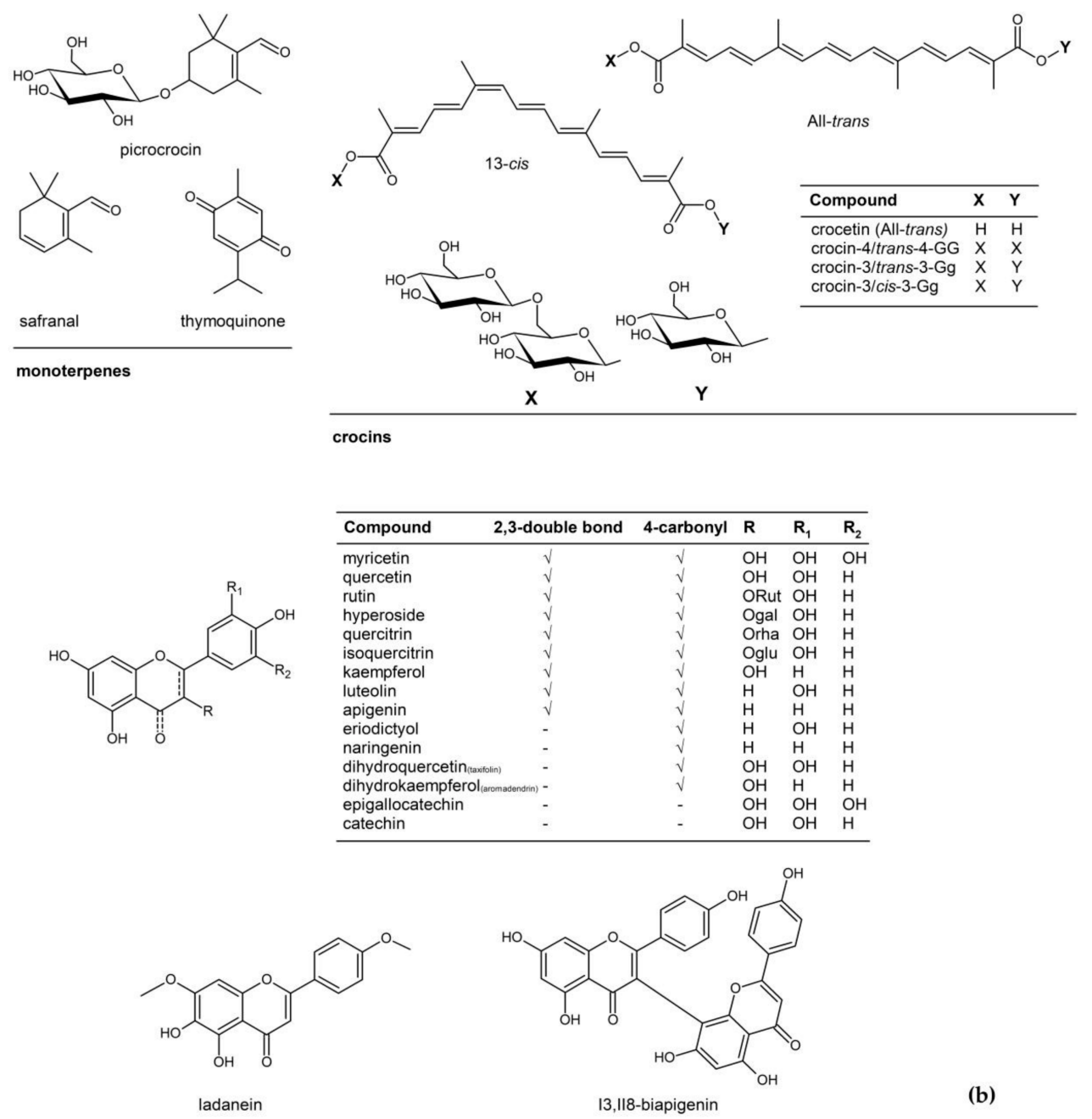

\begin{tabular}{|c|c|c|c|c|c|}
\hline Compound & 2,3-double bond & 4-carbonyl & $\mathbf{R}$ & $\mathbf{R}_{1}$ & $\mathbf{R}_{2}$ \\
\hline myricetin & $\sqrt{ }$ & $\sqrt{ }$ & $\mathrm{OH}$ & $\mathrm{OH}$ & $\mathrm{OH}$ \\
\hline quercetin & 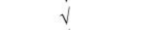 & $\checkmark$ & $\mathrm{OH}$ & $\mathrm{OH}$ & $\mathrm{H}$ \\
\hline rutin & $\sqrt{ }$ & $\sqrt{ }$ & ORut & $\mathrm{OH}$ & $\mathrm{H}$ \\
\hline hyperoside & $\checkmark$ & v & Ogal & $\mathrm{OH}$ & $\mathrm{H}$ \\
\hline quercitrin & $\sqrt{ }$ & $\sqrt{ }$ & Orha & $\mathrm{OH}$ & $\mathrm{H}$ \\
\hline isoquercitrin & v & 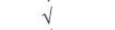 & Oglu & $\mathrm{OH}$ & $\mathrm{H}$ \\
\hline kaempferol & $\checkmark$ & $\sqrt{ }$ & $\mathrm{OH}$ & $\mathrm{H}$ & $\mathrm{H}$ \\
\hline luteolin & $\sqrt{ }$ & $\sqrt{ }$ & $\mathrm{H}$ & $\mathrm{OH}$ & $\mathrm{H}$ \\
\hline apigenin & $\sqrt{ }$ & $\sqrt{ }$ & H & $\mathrm{H}$ & $\mathrm{H}$ \\
\hline eriodictyol & - & v & $\mathrm{H}$ & $\mathrm{OH}$ & $\mathrm{H}$ \\
\hline naringenin & - & v & $\mathrm{H}$ & $\mathrm{H}$ & $\mathrm{H}$ \\
\hline dihydroquercetin (axthaln) & (n) & $\sqrt{ }$ & $\mathrm{OH}$ & $\mathrm{OH}$ & $\mathrm{H}$ \\
\hline dihydrokaempferol larom & omatondany - - & v & $\mathrm{OH}$ & $\mathrm{H}$ & $\mathrm{H}$ \\
\hline epigallocatechin & - & - & $\mathrm{OH}$ & $\mathrm{OH}$ & $\mathrm{OH}$ \\
\hline catechin & - & - & $\mathrm{OH}$ & $\mathrm{OH}$ & $\mathrm{H}$ \\
\hline
\end{tabular}

|3,||8-biapigenin

(b)

flavonoids

Figure 1. The structures of representative members from different groups of bioactives, contained in the reviewed aromatic plants. (a): Hydroxybenzoic acids, hydroxycinnamic acids and derivatives, phenolic diterpenes, triterpenic acids, phloroglucinols, and naphthodianthrones. (b): Monoterpenes, crocins, and flavonoids.

Another family is Hypericaceae, with most known among its genera the Hypericum perforatum (St. John's wort). H. perforatum contains several flavonoids but also phloroglucinols (hyperforins) and naphtodianthrones (hypericins) that have been broadly examined for antioxidant activity and health effects the last decades. The plant has been traditionally used as a food supplement but also as a mild remedy. Crocus sativus (saffron) is another valuable herb, belonging to the Iridaceae family, which contains glycosylated $C_{20}$ apocarotenoids, named crocins. Crocins are water-soluble compounds and have been recently associated with the treatment of various pathological disorders. The stigmas of the plant contain also safranal, the main aromatic compound that defines C. sativa as one of the most precious spices, and picrocrocin, a bitter taste glucoside of $\mathrm{C}_{10}$ apocarotenoid.

The present paper focuses on rosemary, oregano, pink savory, lemon balm, St. John's wort, and saffron, as they are six common herbs with distinctive antioxidant bioactive components. The solvents and the methods used for the recovery and isolation of these components have been extensively reviewed. These methods often depend upon the particular class of antioxidant compounds and, to a lesser extent, on the nature of the matrix, but in general include solvent extraction, and may incorporate precautionary measures to protect the phenolic compounds, or green solvents to be environmentally 
friendly. Finding effective and feasible methods for the separation and purification of natural extracts rich in bioactive antioxidant compounds is a challenge for their industrial production and commercialization.

\section{Rosemary}

Rosemary (Rosemarinus officinalis L.) belongs to the Lamiaceae family and is native to the Mediterranean region and part of Asia, but can withstand cool climates and drought. Its name derives from the Latin ros-marinus, meaning "dew of the sea", because it was believed to survive with no watering, only with the dew coming from the sea. It is the most well-known plant with antioxidant activity and its extract is the only currently approved natural antioxidant in EU (Directive 95/2/EC), assigned the E number E-392 (European Union Directives 2010/67/EU and 2010/69/EU). The antioxidant potency is primarily attributed to the phenolic diterpenes, carnosic acid and carnosol, and secondly to rosmarinic acid (and possibly other hydroxycinnamic acids, like caffeic acid), and minor flavonoid constituents (Figure 1). For this reason, the commercially available formulas of E-392 are standardized according to their content in carnosic acid and carnosol. The same constituents have been associated with several antifungal, antimicrobial, bioplaguicide, anticarcinogenic, anti-inflammatory, and prophylactic effects of rosemary extracts [8,10-14]. Rosemary and some common salvia species are the only herbs that contain carnosic acid and carnosol as major constituents [15]. Other compounds derived through carnosic acid and carnosol degradation like rosmanol, epirosmanol, epirosmanol ethyl ether, rosmadial, and methylcarnosate may be also present in the extracts $[16,17]$. The presence of triterpenoid acids, i.e., ursolic and oleanolic has been also reported [18]. The main flavonoids of the plant are apigenin, luteolin and other flavones, found mostly as glucosides [17,19-21]. All the identified compounds reported in the literature are presented in supplementary material (Table S1).

Carnosic acid and carnosol are compounds of medium polarity and therefore are effectively extracted with acetone or ethanol [21-25]. Other non-polar solvents like hexane and butanone proved also effective [24,25]. The extraction of carnosic acid in a shaking bath was enhanced with temperature $\left(25-50^{\circ} \mathrm{C}\right)$ and time (30-180 $\left.\mathrm{min}\right)$, while butanone was more effective than ethanol, due to lower polarity [24]. The presence of water in mixtures with organic solvents decreases the extraction yield [21]. Confirming this observation, the fresh plant material presented lower carnosic acid extraction yield than the dried material due to the presence of water that combined with ethanol, which was used as solvent, resulting in a more polar solvent $[24,26]$. Additionally, carnosic acid is oxidized to carnosol and derivatives during extraction in the presence of water [27]. Comparing ethanol and methanol as solvents, it was found that the less polar ethanol is effective for the extraction of carnosic acid, while methanol for rosmarinic acid [26]. Water is an excellent solvent for rosmarinic acid, while increasing the organic solvents concentration in water decreases its extraction yield [21].

De AR Oliveira et al. [22] examined acetone, methanol, ethanol, and their mixtures with water for the quantitative recovery of rosmarinic acid, carnosol, and carnosic acid, and observed that ethanol $59-70 \%$ or acetone $80 \%$ gave similar results, while methanol $50 \%$ presented lower carnosic acid recovery due to its transformation to carnosol. Consequently, they used a central composite design to optimize the conditions for the simultaneous extraction of the three compounds with ethanol-water mixtures. Optimum conditions were defined as $70 \%$ ethanol in water, at a solid to liquid ration of 1:5, and extraction time $55 \mathrm{~min}$, to recover $90 \%$ of the antioxidants, while achieving a high purity of the extract. Additionally, ethanol concentrations varying between $30 \%$ and $96 \%$ were tested in maceration experiments and 50\% ethanol in water showed the highest phenolic yield and antioxidant activity [28]. Ethanol-water mixtures are considered green solvents and, therefore have been used by other researchers [4,29]. Psarrou et al. [21] examined ethanol or acetone mixtures with water and observed the highest total phenolic content (TPC) recovery, antiradical activity, and extraction selectivity with either ethanol $60 \%$ or acetone $60 \%$. 
Mixtures of organic solvents with water are more effective than pure water because they can extract more quantitatively non-polar, e.g., phenolic diterpenes and flavonoid aglycones, plus polar compounds (phenolic acids and flavonoid glycosides). Furthermore, they examined the extraction kinetics and observed a fast initial extraction stage, followed by a much slower one, both of them following the unsteady state diffusion law. The increase of temperature $\left(22-60^{\circ} \mathrm{C}\right)$ enhanced swelling of the raw material, solubilization and diffusion of the solutes, thereby, and increased the extraction rate, but decreased selectivity as more non-flavonoid compounds were simultaneously extracted. Total terpenoids recovery increased with temperature but a high portion of carnosic acid was transformed to carnosol at $60{ }^{\circ} \mathrm{C}[21]$.

The main research results about the effect of extraction solvent and procedure are summarized in Table 1. Apart from the conventional solvent extraction (CSE), novel extraction methods, and, among them, ultrasound assisted extraction (UAE), has been examined by many researchers. UAE decreased extraction time and lead to more effective extraction, at lower temperature with less dependence on solvent [23,24]. In particular, it was found to markedly increase the efficiency of ethanol to extract carnosic acid and to enhance the antioxidant activity of the extract $[24,26]$. Both the extraction rate and the TPC yield increased by UAE compared to conventional solid liquid extraction performed under the same conditions, and the difference was more pronounced when ethanol $60 \%$ in water was used as a solvent instead of acetone $60 \%$ [21]. The fact can be explained by the lower penetration and solubilization ability of ethanol that is enhanced by UAE. Ultrasound intensifies mass transfer, due to collapse of cavitation bubbles near the cell walls that causes partial destruction of the cell walls and production of an ultrasonic jet, which may act as a micropump that can force solvent into the cell and dissolve the solutes [24]. Thus, UAE resulted in a meaningful shortening of processing time at about 10-12 $\mathrm{min}[21,30,31]$. 
Table 1. Solvents and methods reported in literature for the extraction of phenolic compounds from rosemary.

\begin{tabular}{|c|c|c|c|c|}
\hline Solvent & Method & Measured Parameters & Main Results & Reference \\
\hline $\begin{array}{l}\text { Butanone } \\
\text { Ethyl acetate Ethanol (solid /liquid 1/10, w/v) }\end{array}$ & $\begin{array}{l}\text { CSE }\left(25-50^{\circ} \mathrm{C}, 0.25-3 \mathrm{~h}\right) \\
\text { UAE (probe } 20 \mathrm{kHz}) \\
\text { UAE (bath } 40 \mathrm{kHz})\end{array}$ & CA & $\begin{array}{l}\text { CA yield increased with temperature. } \\
\text { UAE probe or bath gave similar results and decreased extraction time }(0.25 \mathrm{~h} \\
\left.\text { compared to } 3 \mathrm{~h} \text { at } 50{ }^{\circ} \mathrm{C} \text { by CSE to obtain } 15 \mathrm{mg} \text { CA } / \mathrm{g} \text { dry plant }\right)\end{array}$ & [24] \\
\hline $\begin{array}{c}\text { Ethanol } \\
\text { Methanol } \\
\text { (solid /liquid } 1 / 20, w / v)\end{array}$ & $\begin{array}{l}\text { CSE } \\
\text { UAE (probe } 20 \mathrm{kHz}) \\
\text { UAE (bath } 40 \mathrm{kHz} \text { ) } \\
25-50^{\circ} \mathrm{C}, 0.25-2.0 \mathrm{~h}\end{array}$ & $\begin{array}{l}\text { CA } \\
\text { RA } \\
\text { DPPH }\end{array}$ & $\begin{array}{l}\text { Ethanol gave higher yield of CA and methanol of RA and antiradical activity. } \\
\text { UAE leads to more effective extraction, at lower temperature with less } \\
\text { dependence on solvent } \\
\text { Scale up (125 L) with ethanol resulted in } 22 \text { and } 1.6 \mathrm{mg} / \mathrm{g} \text { dry plant for CA } \\
\text { and RA, respectively. }\end{array}$ & [26] \\
\hline $\begin{array}{l}\text { Hexane } \\
\text { Acetone } \\
\text { Ethanol } \\
\text { Water } \\
\text { (solid } / \text { liquid } 1 / 10, w / v)\end{array}$ & $\begin{array}{l}\text { UAE (probe } 20 \mathrm{kHz}, 10 \mathrm{~min} \text { ) } \\
\text { MAE (under } \mathrm{N}_{2}, 100^{\circ} \mathrm{C}, 10 \mathrm{~min} \text { ) } \\
\text { UAE: Single or successive extractions }\end{array}$ & HPLC & $\begin{array}{c}\text { UAE with ethanol or acetone gave the highest terpenoids yield. Highest TPC } \\
\text { was obtained with UAE or MAE with ethanol ( } 35 \text { and } 36 \mathrm{mg} / \mathrm{g} \text { dry } \\
\text { plant, respectively). } \\
\text { UAE with hexane showed a high selectivity in CA extraction, and with } \\
\text { acetone low CA oxidation }\end{array}$ & [25] \\
\hline $\begin{array}{l}\text { Ethanol } \\
\text { Methanol } \\
\text { Acetone } \\
\text { Water mixtures }\end{array}$ & $\begin{array}{l}\text { CSE } \\
\text { (ethanol in water } 44.8-95.2 \% \text {, solid/liquid } \\
1 / 4.6-1 / 21.4, m / v \text {, time } 4.8-55.2 \mathrm{~min} \text { ) }\end{array}$ & $\begin{array}{l}\mathrm{CA} \\
\mathrm{COH} \\
\mathrm{RA}\end{array}$ & $\begin{array}{l}\text { Ethanol } 59 \% \text { or } 70 \% \text { and acetone } 80 \% \text { gave the best results for all } \\
\text { three compounds. } \\
\text { Optimum conditions: ethanol } 70 \% \text {, solid/liquid } 1 / 5 \text {, extraction time } 55 \text { min } \\
\text { to obtain highest yield and antioxidant concentration in the extract }\end{array}$ & [22] \\
\hline $\begin{array}{l}\text { Ethanol in water }(0-96 \%) \\
\text { Acetone in water }(0-100 \%) \\
\text { (solid /liquid } 1 / 20, w / v)\end{array}$ & $\begin{array}{c}\text { CSE } \\
\text { UAE } \\
\text { Pretreatment: deoiling by water-steam } \\
\text { distillation, milling, maceration }\end{array}$ & $\begin{array}{c}\text { TPC } \\
\text { HPLC DPPH }\end{array}$ & $\begin{array}{l}60 \% \text { ethanol or acetone showed the highest TPC yield and concentration in } \\
\text { the extract. Highest RA yield was obtained with water gave, flavonoids with } \\
60 \% \text { acetone, and terpenes with } 80 \% \text { acetone UAE enhanced TPC extraction } \\
\text { and antiradical capacity of the extract, especially with ethanol } 60 \% \text {. } \\
\text { Grinding increased the extraction rate. }\end{array}$ & {$[21]$} \\
\hline $\begin{array}{c}\text { Ethanol } \\
\text { water } \\
\text { (solid/liquid } 1 / 6, w / v)\end{array}$ & $\begin{array}{c}\mathrm{CSE}\left(40^{\circ} \mathrm{C}, 4 \mathrm{~h}\right) \\
\mathrm{UAE} \text { (probe) } \\
\text { MAE } \\
\text { Pretreatment: deoiling by solvent free MAE, } \\
\text { milling }\end{array}$ & $\begin{array}{l}\text { Yield } \\
\text { TPC } \\
\text { CA } \\
\text { RA } \\
\text { DPPH }\end{array}$ & $\begin{array}{l}\text { CA not detected in water extracts. } \\
\text { Higher yields of TPC, RA and lower EC } \mathrm{C}_{50} \text { in water extracts. } \\
\text { UAE and MAE decreased extraction time. } \\
\text { De-oiling and milling increased yield, TPC and RA content in the extract. }\end{array}$ & [23] \\
\hline $\begin{array}{l}\text { Ethanol in water } \\
\text { Water }\end{array}$ & $\begin{array}{r}\text { CSE (solid/liquid } 1 / 10-1 / 20, m / v, 27-70{ }^{\circ} \mathrm{C}, \\
30-300 \mathrm{~min} \\
\text { UAE probe (solid/liquid } 1 / 20, m / v, 40-90 \% \\
\text { ethanol in water, } 40^{\circ} \mathrm{C}, 60-200 \mathrm{~W}, 3-13 \mathrm{~min} \text { ) }\end{array}$ & $\begin{array}{l}\text { Yield } \\
\text { TPC } \\
\text { DPPH }\end{array}$ & $\begin{array}{c}30 \text { min by CSE or } 11 \text { min for UAE were sufficient to obtain the maximum TPC } \\
\text { and antiradical efficiency. } \\
\text { Combination of CSE (step 1) and UAE (step 2) did not improve results. } \\
56 \% \text { ethanol presented best results in either CSE or UAE }\end{array}$ & [31] \\
\hline $\begin{array}{l}\text { Ethanol in water } \\
\quad 70 \%, 90 \% \\
\text { Water }+ \text { Tween } 20 \\
\text { (solid /liquid } 1 / 15, w / v \text { ) }\end{array}$ & $\begin{array}{c}\text { UAE bath } \\
\text { Maceration (90\% ethanol, room temperature, } \\
48 \mathrm{~h}) \\
\text { Percolation }\end{array}$ & $\begin{array}{l}\text { TPC } \\
\text { RA } \\
\text { UA } \\
\text { OA } \\
\text { DPPH }\end{array}$ & $\begin{array}{l}\text { The highest yield of UA }(15.8 \mathrm{mg} / \mathrm{g}) \text { was obtained by UAE with } 90 \% \text { ethanol, } \\
60^{\circ} \mathrm{C}, 10 \mathrm{~min} \text {; RA }\left(15.4 \mathrm{mg} / \mathrm{g} \text { ) by UAE with } 70 \% \text { ethanol, } 50^{\circ} \mathrm{C}, 30 \mathrm{~min} \text {, or }\right. \\
\text { water (at } \mathrm{pH} 9) ; \text { and OA }(12.2 \mathrm{mg} / \mathrm{g} \text { ) by maceration. } \\
\text { Highest TPC was obtained by water extraction. }\end{array}$ & [18] \\
\hline
\end{tabular}


Table 1. Cont.

Solvent

Method

Method

Measured Parameters

Main Results

Reference

Heat reflux extraction $\left(78^{\circ} \mathrm{C}, 0.5\right.$ or $\left.5 \mathrm{~h}\right)$ Maceration $\left(40^{\circ} \mathrm{C}, 0.5 \mathrm{~h}\right)$

Ethanol in water $90 \%$

(solid/liquid 1/20, w/v)

UAE bath/reactor/probe $\left(40^{\circ} \mathrm{C}, 0.5 \mathrm{~h}\right)$

MAE under reflux $\left(78{ }^{\circ} \mathrm{C}, 0.5 \mathrm{~h}\right)$

under $\mathrm{N}_{2}$ pressure

under vapor pressure

RA
CA
UA
$\mathrm{COH}$

TPC

TPC
DPPH

Percolation

(2)

MAE (4 min, under $\mathrm{N}_{2}$ )

TPC
HPLC

Methanol:water (60:40)

Acetone:water (60:40)

Ethyl acetate:water (60:30)

Heat reflux extraction $\left(90^{\circ} \mathrm{C}, 2 \mathrm{~h}\right.$, under $\left.\mathrm{N}_{2}\right)$

HPLC

(solid/liquid 1/40, w/v, 1/20 in MAE)

Methanol:water 50:50-100:0

Ethanol:water (70:30)

Acetone:water (70:30)

Ethyl acetate:water (70:30)

(solid/liquid 1/5, w/v)

\section{MAE $(2 \times 1-2 \times 15 \mathrm{~min})$ \\ UAE bath $(2 \times 5 \mathrm{~min})$ \\ Soxhlet (1-5 h)}

TPC flavonoids,

anthocyanins

Heat reflux extraction for $0.5 \mathrm{~h}$ resulted in extraction yield of $19 \%$, compared to $10 \%$ obtained by maceration

UAE with probe showed similar yield to heat reflux extraction but higher recovery of CA and UA.

In MAE, extraction and RA yields increased with temperature but CA and UA yield decreased.

Pressure does not enhance extraction.

Highest TPC obtained with 50\%, no significant differences in antiradical activity Percolation gave higher TPC yield but lower antiradical activity.

MAE gave comparable TPC yield to conventional extraction at shorter time Acetone in water presented highest TPC yield in MAE.

Water presented the highest TPC in heat reflux extraction followed by

methanol, acetone and ethyl acetate in water mixtures.

Content of individual phenolics was similar in either method

MAE gave comparable TPC yield with the optimum obtained in Soxhlet extraction $(3 \mathrm{~h})$, and 2-fold higher than UAE.

flavonoids with ethanol:water, 70:30, anthocyanins ethanol:water, 70:30 + 1\%

$$
\mathrm{HCl} \text {, for } 2 \times 5 \mathrm{~min}
$$

\begin{tabular}{|c|c|c|c|c|}
\hline Methanol in water $32-88 \%$ & $\begin{array}{c}\text { Maceration }(1 / 50, w / v, 80 \% \text { methanol, room } \\
\text { temperature, overnight }) \\
\text { ASE }\left(66-200{ }^{\circ} \mathrm{C}, 103 \mathrm{~atm}\right)\end{array}$ & $\begin{array}{l}\text { TPC, } \\
\text { HPLC } \\
\text { FRAP }\end{array}$ & $\begin{array}{l}\text { Optimum conditions through RSM: } 56 \% \text { methanol, } 129^{\circ} \mathrm{C} \text {. } \\
\text { TPC (101.7 mg/g dry herb) and antioxidant recovery at optimum ASE } \\
\text { conditions were higher than those obtained by solid/liquid extraction. }\end{array}$ & {$[30]$} \\
\hline $\begin{array}{c}\text { Ethanol } \\
\text { Water } \\
\text { (solid } / \text { liquid } 1 / 10, w / v) \\
\mathrm{CO}_{2} \\
\mathrm{CO}_{2}+7 \% \text { ethanol }\end{array}$ & $\begin{array}{c}\text { ASE }\left(50-200^{\circ} \mathrm{C}, 100 \mathrm{bar}, 20 \mathrm{~min}\right) \\
\operatorname{SFE}\left(40^{\circ} \mathrm{C}, 100-400 \mathrm{bar}, 300 \mathrm{~min}\right) \\
\text { WEPO }\end{array}$ & $\begin{array}{l}\text { TPC } \\
\text { DPPH } \\
\text { HPLC }\end{array}$ & $\begin{array}{l}\text { ASE with water gave the highest yield and antioxidant activity of the extract. } \\
\text { TPC, yield and antiradical activity increased with temperature and water was } \\
\text { more efficient than ethanol. } \\
\text { The extract obtained by SFE with } \mathrm{CO}_{2}+7 \% \text { ethanol had good TPC and } \\
\text { antiradical activity but low yield. }\end{array}$ & [34] \\
\hline $\begin{array}{c}\text { Ethanol } \\
\text { Water } \\
\text { (solid /liquid } 1 / 10, w / v) \\
\mathrm{CO}_{2} \\
\mathrm{CO}_{2}+6.6 \% \text { ethanol } \\
\end{array}$ & $\begin{array}{c}\text { ASE }\left(150^{\circ} \mathrm{C} \text { with ethanol, } 100 \text { or } 200^{\circ} \mathrm{C} \text { with }\right. \\
\text { water, } 100 \text { bar, } 20 \text { min }) \\
\text { SFE } \\
\left(40^{\circ} \mathrm{C}, 150,400 \text { bar }\right)\end{array}$ & HPLC & $\begin{array}{l}\text { SFE extracted compounds of low polarity. } \\
\text { RA was extracted by ASE with either solvent, while most flavonoid glycosides } \\
\text { were extracted only by ASE with water }\end{array}$ & [19] \\
\hline $\begin{array}{l}\text { Ionic liquids in water } \\
\text { (solid/liquid } 1 / 20, w / v)\end{array}$ & $\begin{array}{c}\text { UAE (bath } 100-250 \mathrm{~W}, 0.5 \mathrm{~h} \text {, after } 2 \mathrm{~h} \\
\text { soaking) }\end{array}$ & $\begin{array}{l}\text { CA } \\
\text { RA }\end{array}$ & $\begin{array}{l}\text { The extraction efficiency was comparable to } 80 \% \text { ethanol used in UAE }(0.5 \mathrm{~h}) \text {, } \\
\text { solvent extraction }(24 \mathrm{~h}) \text { or CSE }(24 \mathrm{~h}) \text {. }\end{array}$ & [35] \\
\hline
\end{tabular}

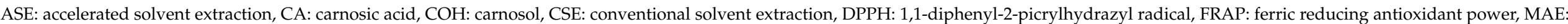

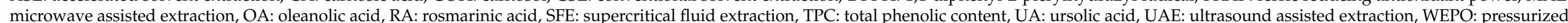
water extraction with particle on-line formation. 
Bellumori et al. [25] examined UAE with different solvents in single or successive extraction steps. Ethanol and acetone gave the highest TPC yield, while water the lowest due to its inability to extract terpenoids, although it was the most effective for the recovery of rosmarinic acid and flavonoids. Additionally, sonication of water results in the formation of highly reactive hydroxyl radicals, which may participate to degradation reactions. The highest terpenoid recovery was obtained with acetone, accompanied with very limited oxidation of carnosic acid. Hexane presented low overall yield but a very high selectivity in terpenoids extraction. Thus, the authors concluded that UAE can be very favorably compared with the CSE in acetone that is used to prepare commercial rosemary antioxidants [25]. The investigation of the optimal conditions for the extraction of rosmarinic acid, ursolic acid, and oleanolic acid from rosemary leaves by UAE or maceration $(90 \%$ ethanol, $48 \mathrm{~h}$ ) indicated UAE with 70\% ethanol the most efficient for rosmarinic acid recovery, UAE with $90 \%$ ethanol for ursolic acid, and maceration for oleanolic acid. Maceration showed also the highest TPC yield and antioxidant activity [18]. UAE performed with a probe presented higher extraction yield and carnosic acid and ursolic acid recovery, compared to a bath, possibly due to a better ultrasonic power delivery [29]. The results obtained at $40{ }^{\circ} \mathrm{C}$ for $30 \mathrm{~min}$ were comparable or slightly better than those obtained by conventional extraction at $78^{\circ} \mathrm{C}$ for $30 \mathrm{~min}$, except for rosmarinic acid that presented lower yield [29]. It is generally recommended to use reactors with $20 \mathrm{kHz}$ as operating frequency in the case of UAE with a probe because, at lower frequencies of irradiation (e.g., $20 \mathrm{kHz}$ ), the physical effects of ultrasound-induced cavitation phenomena, i.e., liquid circulation currents and turbulence that are the controlling factors in extraction, are dominant $[4,24,25,29,36]$.

Microwave assisted extraction (MAE) has been also examined [25,29,32,33]. MAE performed with water resulted in lower TPC yield than a conventional heat reflux extraction, while this was not observed when water mixtures with acetone, methanol, or ethyl acetate were used [32]. Water has a high dielectric constant but a low dissipation factor, compared to the other solvents. Thus, the rate of microwave energy absorbance is higher than the rate of heat dissipation, resulting in overheating and possibly destruction of some of the phenolic compounds [32]. Mixtures of methanol or acetone with water (70:30) presented the highest TPC yield [32,33], while mixture of ethanol with water (70:30) proved the most efficient for flavonoids [25,33], and, when acidified with $1 \% \mathrm{HCl}$, for anthocyanins [33]. The increase of temperature $\left(78-150{ }^{\circ} \mathrm{C}\right)$ in MAE with $90 \%$ ethanol increased the extraction yield and rosmarinic acid recovery but decreased carnosic acid and ursolic acid recovery. Additionally, the use of vapor or $\mathrm{N}_{2}$ pressure was examined but did not enhance extraction yield [29].

Solid free microwave extraction (SFME) has been used mainly for the recovery of $\mathrm{EO}[9,37,38]$. The principle of the method is the internal heating of the in-situ water of the plant by microwaves, which leads to rupture of the glands and oleiferous receptacles. The released EOs and bioactive compounds are evaporated with the in situ water of the plant material. If SFME is performed under pressure, at high temperature (around $180^{\circ} \mathrm{C}$ ), the polarity and viscosity of the water decrease and it can dissolve, and consequently, extract less polar compounds like flavonoid aglycons that are not soluble at atmospheric temperature and pressure [38].

Another approach used for the extraction of antioxidants is the accelerated solvent extraction (ASE) that is also defined as pressurized liquid extraction (PLE), and in case water is used as the solvent, pressurized water or pressurized hot water extraction (PWE, PHWE), or subcritical water extraction (SWE). Similar to UAE and MAE, ASE has several environmental and economic advantages compared to CSE. It is a fast extraction technique, requiring lower amounts of solvents, while non-toxic solvents like ethanol or water can be effectively used. In particular, when applying ASE with water, the polarity of water decreases as temperature increases while it remains at the liquid stage, thus it approaches the properties of organic solvents [34]. Ethanol proved a good solvent for the recovery of carnosic acid and carnosol by ASE, while rosmarinic acid was equally recovered by either ethanol, or water, and more polar acids (caffeic, chlorogenic) and flavonoid glycosides 
by water $[19,34]$. High temperatures, $150-200{ }^{\circ} \mathrm{C}$, which may be used in ASE, cause degradation of rosmarinic acid [30,34]. Rosmarinic acid may be cleaved to its monomer, caffeic acid, which increased as temperature increased [30]. Additionally, increasing temperature caused an increase in gallic acid, while carnosic acid and carnosol were not affected, and consequently antioxidant capacity was favored. Nevertheless, as temperature increased, melanoidins were formed through Maillard reactions, which may lead to harmful products, thereby ASE at $150-200^{\circ} \mathrm{C}$ was not recommended [30].

Additionally, supercritical fluid extraction (SFE) has been examined by some researchers. SFE with neat $\mathrm{CO}_{2}$ provides very low yield that can be improved with the addition of a modifier such as ethanol $[19,39,40]$. In fact, $\mathrm{CO}_{2}$, as a non-polar solvent, can recover only carnosic acid, carnosol, and other carnosic acid derivatives, even at 400 atm, while the addition of $7 \%$ or $10 \%$ ethanol was necessary for the extraction of minor amounts of other phenolic compounds [19,34,40]. Zabot et al. [41] proposed a sequential extraction of the EO and the phenolic compounds by using supercritical $\mathrm{CO}_{2}$ and $\mathrm{PWE}$ in the same equipment. Water is a polar solvent, thus suitable for rosmarinic acid extraction that was recovered at the beginning of PWE. As temperature increased above $100{ }^{\circ} \mathrm{C}$, the polarity of water was reduced and the less polar compounds, i.e., carnosic acid, carnosol, rosmanol, and methyl carnosate were obtained $[39,41]$.

Another research team proposed a pressurized hot water extraction combined with particle formation on line (WEPO) to obtain dry antioxidant powder from rosemary [34,42]. The extraction is performed at $200^{\circ} \mathrm{C}$ and $80 \mathrm{~atm}$, the extract is continuously transformed to an aerosol by the use of a supercritical $\mathrm{CO}_{2}$ nebulization system, and the aerosol is instantaneously dried by a hot $\mathrm{N}_{2}$ current [42]. After $40 \mathrm{~min}$ of extraction a powder yield of $34 \%$, dry basis, was obtained with good DPPH radical scavenging properties, while no details about the phenolic profile are provided by the authors. The procedure was favorable in terms of environmental impact, compared to PHWE $\left(200^{\circ} \mathrm{C}, 103 \mathrm{~atm}, 20 \mathrm{~min}\right)$ and SFE $\left(40{ }^{\circ} \mathrm{C}, 150 \mathrm{~atm}, 300 \mathrm{~min}\right.$, ethanol as modifier) giving powder with similar antioxidant capacity. Additionally, ionic liquids have been examined, as novel, green solvents [43] but separation of the antioxidant compounds from the extraction liquor needs further research.

The plant material is dried (usually at room temperature) before the extraction so as to avoid microbial spoilage during storage and facilitate transportation. Mulinacci et al. [27] observed that drying caused a significant loss of flavonoids and rosmarinic acid, while total terpenoids were not affected. Additionally, freeze drying caused significant losses [27,44]. Freezing, on the other hand, caused a high loss of rosmarinic acid, possibly due to phenoloxidase activity [27]. On the contrary, grinding of the raw material to smaller particle size, facilitated mass transfer phenomena, and consequently, enhanced extraction [21]. The geographical region, and possibly the soil type, and altitude have an effect on the profile and concentration of the phenolic compounds $[20,45,46]$. The harvesting period has a significant effect on the phenolic content that presents a maximum on flowering period (e.g., May and November), and on flavonoid content that follows the same trend [44]. Furthermore, the highest concentration of carnosic acid and rosmarinic acid present a reverse trend, the former showing a maximum in summer and the latter in winter [45]. However, results for phenolic compounds seasonal variations from plants of different regions and countries do not agree and seem to depend, among others, to variations in temperature and rainfall $[43,46,47]$.

Rosemary extracts have been proposed and used as bioactive, antioxidant additives in food, cosmetics, packaging, etc. [48-52]. Their worldwide market is expected to present an annual growth rate of roughly $3.7 \%$ over the next five years, and will reach 260 million US\$ in 2024 from 210 million US\$ in 2019 [53]. For industrial uses dried extracts have several advantages, e.g., they are easier to handle, transport and store, and to be used in solid formulations like tablets and capsules. Dried extracts have been obtained through spray drying of an ethanol:water (80:20) extract at an inlet temperature of $140^{\circ} \mathrm{C}$. Although the dried products lost some of their polyphenols, they presented appreciable antioxidant activity [54]. Other investigators reported much lower inlet temperature $\left(80^{\circ} \mathrm{C}\right)$ as op- 
timum [55]. Efforts for encapsulation in maltodextrin, through spay drying, presented promising results, too [35].

\section{Oregano}

Oregano is one of the most common and important aromatic and medicinal herbs of the Lamiaceae family. Thousands of tons are consumed every year as a spice and its flavor is highly favorable all over the world. The food industry uses dry oregano as a spice in snacks, salad dressings, etc., where in addition to the desirable flavor it may provide antioxidant protection. Many studies have pointed out the antiviral, anti-inflammatory, and antitumor properties of its EO due to its high content in carvacrol and thymol [56-58]. Although rosemary extract is the only one, among Lamiaceae herb extracts, approved by EU legislation as food antioxidant (additive), the US Food and Drug Administration (FDA) has also recognized oregano EO as a safe and potable substance (generally recognized as safe-GRAS) [59]. Additionally, carvacrol has been approved for food use by the European Union (Commission Implementing Regulation (EU) No 872/2012).

Many oregano plants are widely used under the vernacular name oregano. Although similar in their external appearance, differ in their odor and consequently in their composition. At least 60 species and 17 genera belonging to diverse botanical families are known as oregano [60]. The most common is Origanum vulgare L. (Greek oregano). Oregano population are primarily distributed in Eurasia and African regions, with the highest recorded diversity being in the Mediterranean [61]. Various methods have been used to differentiate extracts of Origanum subspecies from different part of the world, or to isolate and characterize new phenolic compounds [62,63].

Several studies [64-68] have reported oregano as one of the most promising sources for the recovery of polyphenols and consequently for its antioxidant properties, which have been proved to be highly dependent on the total phenolic content. Considerable amounts of phenolic compounds are generally detected in extracts obtained with water, methanol, ethanol, acetone, ethyl acetate, and/or mixtures of them, by using conventional or novel methods. Flavonoids (mainly apigenin, luteolin, quercetin, and their glycosides), and phenolic acids (mainly rosmarinic acid) are the main types of bioactive compounds present in oregano (Table S1) [69-73]. Rosmarinic acid appears the major phenolic component of oregano and its maximum content can be near $23 \mathrm{mg} / \mathrm{g}$ of plant material [74]. A study among oregano herbs of different origin, such as Turkish, Syrian, and Spanish, showed that Syrian is the richest one in rosmarinic and caffeic acid [75]. Additionally, lithospermic acid (and its stereoisomers) was isolated from O. vulgare spp. hirtum, [64,73]. The high antioxidant capacity (DPPH, ABTS, and FRAP) of the O. vulgare methanolic extract was attributed to the large quantity of rosmarinic acid $(23.53 \mathrm{mg} / \mathrm{g}$ of dry extract) and the presence of other active compounds like (-)-epicatechin [76].

The first attempts of obtaining oregano extracts with high antioxidant activity were based either on Soxhlet extraction [67,77], or CSE [68], by using solvents of different polarity. O. vulgare water extract, among the extracts obtained by maceration with water, ethanol, acetone, ethyl acetate, or diethyl ether, proved to have the highest total phenolic content (235 mg GAE/g extract), while diethyl ether extract the highest flavonoid and tannin content (132 mg rutin equivalents/g extract, and $4 \mathrm{mg}$ catechin equivalents/g extract, respectively). Additionally, water obtained the maximum TPC recovery (51 mg GAE/g dry plant) but ethanol, exhibiting a much lower recovery ( $9 \mathrm{mg}$ GAE/g dry plant), had a higher antioxidant activity, indicating that ethanol was a more selective solvent for phenolic compounds and the obtained extract contained less impurities [70]. The successive extraction of $O$. vulgare with ethyl acetate, water, and ethanol led to a combined extract with high antioxidant activity, with quercetin glucoside and apigenin glucoside being the major components ( $49.72 \%$ and $23.70 \%$ of the total flavonoids, respectively) [66]. Mixtures of organic solvents with water have been studied for a more efficient quantitative and qualitative recovery of the desired compounds, than pure solvents, as they can extract rosmarinic, caffeic and other phenolic acids, and the less polar flavonoids and even carvacrol. The use of $80 \%$ 
methanol in water extract indicated a lower content of phenolic compounds compared to the water infusion and decoction, while the analysis revealed the presence of 22 phenolic compounds, with rosmarinic acid being the most abundant phenolic acid (15 mg/g extract) in all the preparations, and luteolin 7-O-glucoside and luteolin O-glucuronide being the most abundant flavonoids (12-28 mg/g extract) [69]. Majeed et al. [78] examined the effect of methanol in aqueous mixture (70-90\%) and found that 70\% methanol resulted in the highest TPC recovery (18.8 $\mathrm{mg}$ GAE/g dry plant after $16 \mathrm{~h}$ of extraction) from 0 . vulgare leaves, accompanied with the highest DPPH radical scavenging capacity. O. vulgare spp. hirtum $70 \%$ aqueous-methanol extract, obtained by UAE, contained a high amount of total phenolics (49.9 mg GAE/g extract, dry basis), rosmarinic acid (12.0 mg/g extract), and carvacrol (28.8 mg/g extract), and a significant amount of ( \pm )-naringenin and rutin [79]. As ethanol presents similar yields to methanol, it can be used instead of the latter for food or cosmetic uses of the recovered polyphenols, as it is less toxic. O. vulgare spp. hirtum extracts obtained with $60 \%$ ethanol exhibited the highest phenolics recovery (both phenolic acids and flavonoids) and the strongest antiradical activity [64]. In particular, the increase of ethanol content from $0 \%$ to $60 \%$ showed increase in the yield of rosmarinic and lithospermic acid.

The antioxidant capacity of $O$. vulgare is not entirely related to rosmarinic acid, which indicates that other compounds are acting as antioxidant agents [80]. A positive correlation was observed between the TPC and DPPH radical scavenging activity and was attributed to the presence of eriodictyol, apigenin and caffeic acid in the aqueous extract of O. vulgare [81]. Furthermore, eriodictyol and naringenin were also found in the methanolic extract of $O$. vulgare leaves, which exhibited high TPC and a positive correlation with the ORAC value [82].

Changes in the extraction process variables (solid-to-liquid ratio, temperature) can affect both the TPC yield and the phenolic profile of an extract. A solid/liquid of 1/20 proved efficient for the recovery of phenolic antioxidant components from oregano [64,78]. Lower values (e.g., 1/40) did not increase the extraction rate or TPC recovery [64], while values higher than 1/12.5 decreased sharply the TPC recovery in CSE [78]. Experiments with oregano extracted by ethanol at various temperatures revealed that TPC increased as temperature increased in the range of $20-60{ }^{\circ} \mathrm{C}$ [64].

Phenolic compounds are found in both free and bound forms in plant cells. The free phenolics are easily extracted. On the contrary, phenolic compounds covalently-bound to the plant matrix cannot be extracted by water or organic solvents, thus alkaline or acid hydrolysis is needed [2,83]. O. hirtum extraction using $\mathrm{KOH} 1 \%$ or $3 \%$ showed noticeable antiradical activity, with rosmarinic acid content amounting to $5.02 \%$ and $4.66 \%$ in the dry extract, respectively, indicating a possible degradation of rosmarinic acid to caffeic acid, as the latter increased in the extract obtained with $3 \% \mathrm{KOH}$ [2].

Several investigators explored the use of novel methods (ASE, UAE, and SFE) for the extraction of bioactive compounds from oregano, in an attempt to reduce extraction time and solvent and thereby approach green extraction techniques. The main results are summarized in Table 2. By using aqueous methanol mixtures at 103 atm in ASE, oregano showed its optimum extraction condition at $33 \%$ methanol and $129{ }^{\circ} \mathrm{C}$, with the ASE extracts having significantly higher amount of rosmarinic acid $(10.21 \mathrm{mg} / \mathrm{g})$ than the CSE extracts $(5.70 \mathrm{mg} / \mathrm{g}$ ) [30]. It is interesting to note that the optimum methanol concentration was lower than that defined for rosemary extraction (56\%), while the temperature was the same because at higher temperature degradation of luteolin and apigenin glycosides was observed. Rodríguez-Meizoso et al. [84] performed ASE with water at 103 atm and temperature varying from 25 to $200{ }^{\circ} \mathrm{C}$. The yield and phenolics recovery increased with temperature, while the antiradical activity of the extracts obtained at elevated temperature was higher due to the presence of different phenolic compounds (mainly flavonoids). 
Table 2. Solvents and methods reported in literature for the extraction of phenolic compounds from oregano.

\begin{tabular}{|c|c|c|c|c|}
\hline Solvent & $\begin{array}{c}\text { Extraction } \\
\text { Method/Parameters }\end{array}$ & Measured Parameters & Main Results & Reference \\
\hline $\begin{array}{c}\text { Ethanol, } \\
\text { Supercritical } \mathrm{CO}_{2} \\
\text { (Ethanol as modifier) }\end{array}$ & $\begin{array}{c}\text { Focused UAE } \\
(20 \mathrm{kHz}, 10 \mathrm{~min}) \\
\text { SFE } \\
\left(\mathrm{CO}_{2} \text { flow: } 1-2 \mathrm{~mL} / \mathrm{min}, \mathrm{T}:\right. \\
35-60^{\circ} \mathrm{C}, \mathrm{P}: 100-170 \text { atm, } \\
\text { ethanol } 5-40 \%)\end{array}$ & $\begin{array}{c}\text { TPC } \\
\text { TEAC (ABTS) }\end{array}$ & $\begin{array}{c}\text { Optimum conditions determined by } \\
\text { experimental design: } \\
\text { Focused UAE ( } 50 \% \text { amplitude, } 12.5 \mathrm{~min}) \\
\text { SFE }\left(\mathrm{CO}_{2} \text { flow: } 1 \mathrm{~mL} / \mathrm{min}, \mathrm{T}: 40^{\circ} \mathrm{C}, \mathrm{P}:\right. \\
100 \mathrm{~atm}, 40 \% \text { ethanol) } \\
\text { TPC almost twice extracted by means of the } \\
\text { Focused UAE. }\end{array}$ & [85] \\
\hline $\begin{array}{l}\text { Supercritical } \mathrm{CO}_{2} \\
\text { (Ethanol as modifier) }\end{array}$ & $\begin{array}{l}\text { SFE } \\
\left(40-60^{\circ} \mathrm{C}, 150-350 \mathrm{~atm},\right. \\
\text { fractionation of EO and } \\
\text { phenolic compounds })\end{array}$ & $\begin{array}{c}\text { HPLC } \\
\text { DPPH } \\
\beta \text {-carotene-linoleic acid }\end{array}$ & $\begin{array}{l}\text { Extraction yield increased with ethanol. } \\
\text { Higher antioxidant capacity at } 40^{\circ} \mathrm{C}, \\
\qquad 250 \mathrm{~atm} . \\
\text { Dihydroquercetin only extracted with } \\
\text { ethanol as modifier. }\end{array}$ & [86] \\
\hline Water & $\begin{array}{c}\text { ASE } \\
\left(25,50,100,150,200{ }^{\circ} \mathrm{C},\right. \\
103 \text { atm, } 30 \text { min-individual } \\
\text { extractions, or sequential } \\
\text { extractions for } 15 \text { min at } \\
\text { each temperature })\end{array}$ & $\begin{array}{l}\text { TPC } \\
\text { DPPH } \\
\text { HPLC }\end{array}$ & $\begin{array}{l}\text { Extraction yield was higher at individual } \\
\text { extractions, and increased with temperature. } \\
\text { TPC of the extracts was not affected by } \\
\text { temperature, but antioxidant activity } \\
\text { Increased. }\end{array}$ & [84] \\
\hline $\begin{array}{c}\text { Ethanol in water } \\
(0-96 \%) \\
(\mathrm{s} / 11 / 40-1 / 20, w / v)\end{array}$ & $\begin{array}{c}\text { CSE } \\
\text { Temperature }\left(22-60^{\circ} \mathrm{C}\right), \\
\text { particle size } \\
(<315-1000 \mu \mathrm{m})\end{array}$ & $\begin{array}{l}\text { TPC } \\
\text { DPPH } \\
\text { HPLC }\end{array}$ & $\begin{array}{l}\text { Optimum conditions: } 60 \% \text { ethanol, s/1 1/20, } \\
22{ }^{\circ} \mathrm{C}, 600 \mu \mathrm{m} . \\
\text { Increase of ethanol up to } 60 \% \text { increased RA } \\
\text { and lithospermic acid yield. }\end{array}$ & {$[64]$} \\
\hline $\begin{array}{c}\text { Methanol in water } \\
(70-90 \%) \\
(\mathrm{s} / 11 / 20-1 / 5, w / v)\end{array}$ & $\begin{array}{c}\text { CSE } \\
\text { (Extraction time } \\
4,10,16 \mathrm{~h}, \\
\text { particle size 20,65, } \\
110 \mu \mathrm{m})\end{array}$ & $\begin{array}{c}\mathrm{TPC} \\
\mathrm{DPPH}\end{array}$ & $\begin{array}{l}\text { All examined parameters were significant. } \\
\text { Optimum conditions (RSM): } \\
\mathrm{MeOH}(70 \%) \text {, s } / 11 / 20 \text {, time } 16 \mathrm{~h} \text {, particle } \\
\text { size } 20 \mu \mathrm{m} \\
\text { TPC (18.75 } \mathrm{mg} / \mathrm{g} \text { dry herb) }\end{array}$ & [78] \\
\hline $\begin{array}{l}\text { Methanol in water } \\
\qquad(32-80 \%)\end{array}$ & $\begin{array}{c}\text { Maceration } \\
(\mathrm{s} / 11 / 50, w / v, \\
80 \% \text { methanol, } \\
\text { overnight }) \\
\text { ASE } \\
\left(66-200^{\circ} \mathrm{C}, 103 \mathrm{~atm}\right)\end{array}$ & $\begin{array}{l}\text { TPC } \\
\text { FRAP } \\
\text { HPLC }\end{array}$ & $\begin{array}{c}\text { Optimum ASE conditions (RSM): } \\
33 \% \text { methanol, } 129^{\circ} \mathrm{C} \text {. } \\
\text { TPC and FRAP at optimum ASE conditions } \\
\text { were higher than those obtained } \\
\text { by maceration. } \\
\text { RA and luteolin-7-O-glucoside showed a } \\
\text { decrease at T } \geq 150^{\circ} \mathrm{C} \text { in comparison to } \\
\text { optimum ASE. }\end{array}$ & {$[30]$} \\
\hline $\begin{array}{c}\text { Ethanol in water } 90 \% \text {, } \\
v / v \text { s } / 11 / 100 \\
\text { Ethanol in propylene } \\
\text { glycol }(10-30 \%) \\
\text { Ethanol in glycerol } \\
(1-20 \%)\end{array}$ & $\begin{array}{c}\text { CSE } \\
\left(25^{\circ} \mathrm{C}, 24 \mathrm{~h}\right) \\
\text { Heat-reflux } \\
\left(95^{\circ} \mathrm{C}, 1-6 \mathrm{~h}\right) \\
\text { Maceration } \\
(\mathrm{s} / 11 / 100,24 \mathrm{~h} \text { or } 1 / 5, \\
48 \mathrm{~h}) \\
\text { Percolation } \\
\left(25^{\circ} \mathrm{C}, 48 \mathrm{~h}\right) \\
\text { UAE } \\
(\text { Ethanol 30-96\%, } \\
\mathrm{s} / 11 / 20,25-60^{\circ} \mathrm{C}, \\
10 \mathrm{~min})\end{array}$ & $\begin{array}{l}\text { RA } \\
\text { UA } \\
\text { OA } \\
\text { CAR }\end{array}$ & $\begin{array}{c}\text { Heat reflux and CSE gave the highest yields, } \\
\text { while percolation the lowest. } \\
\text { During heat reflux: Ethanol in non-aqueous } \\
\text { solvents was more effective. } \\
\text { Highest RA: Heat reflux (Ethanol, } 90 \% v / v \text {, } \\
6 \mathrm{~h} \text { ) } \\
\text { Highest OA, UA: Maceration (Ethanol, } 90 \% \\
v / v, 1 / 5,48 \mathrm{~h} \text { ) } \\
\text { Highest CAR: UAE } \\
\text { (Ethanol, } 96 \% v / v, 25^{\circ} \mathrm{C} \text { ) or } \\
\text { Continuous stirring }\end{array}$ & [65] \\
\hline $\begin{array}{c}\text { Methanol in water } 80 \% \\
v / v \\
\text { Water }\end{array}$ & $\begin{array}{c}\text { CSE } \\
\left(25^{\circ} \mathrm{C}, 60 \mathrm{~min}, 150 \mathrm{rpm}\right) \\
\text { Infusion }(5 \mathrm{~min}) \\
\text { Decoction } \\
\text { (boiling in water, } 5 \mathrm{~min})\end{array}$ & $\begin{array}{c}\text { HPLC DPPH } \\
\beta \text {-carotene-linoleic acid } \\
\text { lipid peroxidation }\end{array}$ & $\begin{array}{c}\text { CSE extracts showed higher antimicrobial } \\
\text { activity. Higher TPC, flavonoids and } \\
\text { antioxidant capacity by decostion }> \\
\text { infusion }>\text { CSE }\end{array}$ & {$[69]$} \\
\hline $\begin{array}{l}\text { Water, Ethanol, Acetone, } \\
\text { Ethyl acetate, } \\
\text { Diethyl ether }\end{array}$ & $\begin{array}{l}\text { Maceration } \\
\text { (Three times, } \\
25^{\circ} \mathrm{C}, 24 \mathrm{~h} \text { ) }\end{array}$ & $\begin{array}{c}\text { TPC } \\
\text { Flavonoids Condensed } \\
\text { tannins DPPH }\end{array}$ & $\begin{array}{c}\text { Highest TPC: water } \\
\text { Highest flavonoids: Diethyl ether } \\
\text { Highest Condensed tannins: Diethyl ether } \\
\text { Highest antioxidant capacity: Ethanol }\end{array}$ & {$[70]$} \\
\hline $\begin{array}{c}\text { Methanol in water } 70 \% \text {, } \\
v / v \\
\text { Water }\end{array}$ & $\begin{array}{c}\text { UAE (bath) } \\
\left(\mathrm{T}<30^{\circ} \mathrm{C}, 20 \mathrm{~min}\right)\end{array}$ & $\begin{array}{l}\text { DPPH } \\
\text { FRAP } \\
\text { ABTS } \\
\text { HPLC }\end{array}$ & $\begin{array}{l}\text { Hydroalcoholic extract contained higher RA, } \\
\text { CAR and TPC. }\end{array}$ & [79] \\
\hline
\end{tabular}


Table 2. Cont.

\begin{tabular}{|c|c|c|c|c|}
\hline Solvent & $\begin{array}{c}\text { Extraction } \\
\text { Method/Parameters }\end{array}$ & Measured Parameters & Main Results & Reference \\
\hline $\begin{array}{l}\text { Methanol in water } 80 \% \text {, } \\
\qquad / v\end{array}$ & $\begin{array}{c}\text { UAE } \\
(12.5 \mathrm{kHz}, 30 \mathrm{~min})\end{array}$ & $\begin{array}{l}\text { TPC } \\
\text { HPLC } \\
\text { ORAC }\end{array}$ & $\begin{array}{l}\text { There is a correlation between ORAC and } \\
\text { TPC, but not between ORAC and RA. }\end{array}$ & [80] \\
\hline $\begin{array}{c}\text { Water } \\
(\mathrm{s} / 11 / 100, w / v)\end{array}$ & $\begin{array}{c}\text { Infusion } \\
\left(85^{\circ} \mathrm{C}, 15 \mathrm{~min}\right) \\
\text { Infusion } \\
\left(25^{\circ} \mathrm{C}, 15 \mathrm{~min}\right) \\
\text { UAE } \\
\left(35 \mathrm{MHz}, 25^{\circ} \mathrm{C}, 15 \mathrm{~min}\right)\end{array}$ & $\begin{array}{l}\text { TPC } \\
\text { ABTS } \\
\text { DPPH }\end{array}$ & $\begin{array}{l}\text { Hot water showed the highest efficiency for } \\
\text { oregano and lemon balm. Lemon balm had } \\
\text { higher TPC than oregano }\end{array}$ & [87] \\
\hline
\end{tabular}

ABTS: 2,2-azino-bis-3-ethylbenzothiazoline-6-sulfonic acid radical, ASE: accelerated solvent extraction, CAR: carvacrol, CSE: conventional solvent extraction, DPPH: 1,1-diphenyl-2-picrylhydrazyl radical, FRAP: ferric reducing antioxidant power, OA: oleanolic acid, RA: rosmarinic acid, SFE: supercritical fluid extraction, TEAC: trolox equivalent antioxidant capacity, TPC: total phenolic content, UA: ursolic acid, UAE: ultrasound assisted extraction.

Comparing SFE and focused UAE (ultrasound energy is focused in the tip of the ultrasound probe) techniques, the TPC obtained by means of focused UAE was higher and so was the antioxidant capacity of the extract [85]. However, the study of the recovery of carvacrol, rosmarinic, oleanolic, and ursolic acid from three different oregano species (O. onites L., O. vulgare spp. hirtum, and O. vulgare L.), with alcoholic mixtures, by using various extraction techniques, showed that heat extraction $\left(95^{\circ} \mathrm{C}\right)$ under reflux, and continuous stirring extraction at ambient temperature, gave significantly higher values, compared to percolation, maceration and UAE, while heat extraction needed shorter time [65]. The extracted maximum rosmarinic acid amount from $O$. vulgare ssp. hirtum was 3.85 times higher than $O$. vulgare L. and 2.2 from O. onites L. Similarly, water extracts obtained from $O$. vulgare at $85^{\circ} \mathrm{C}$ revealed higher TPC and antioxidant activity than the ones obtained by UAE at room temperature [87].

SFE was applied in order to obtain extracts from $O$. heracleoticum rich in compounds with antioxidant activity but free of the lower molecular weight aromatic compounds. Fractionation by applying $100 \mathrm{~atm}$ at $40{ }^{\circ} \mathrm{C}$, followed by $300 \mathrm{~atm}$ at $40{ }^{\circ} \mathrm{C}$, and $300 \mathrm{~atm}$ at $100{ }^{\circ} \mathrm{C}$, resulted in a partial separation of the components, with a higher content of $\mathrm{EO}$ components in the first fraction, and thymoquinone and a low flavonoid content in the third, which exhibited the strongest antioxidant activity [88]. Furthermore, the addition of ethanol, as a cosolvent, improved the efficiency of SFE and enhanced the coextraction of polar compounds $[85,86]$. Medium polarity molecules, such as the flavonoid aglycons dihydroquercetin, eriodictyol, and dihydrokaempferol, were only extracted with ethanol as modifier. The oregano matrix is relatively soft compared to rosemary, thus SFE with ethanol was more efficient for the extraction and fractionation of oregano flavonoids [86].

As the fresh herb is prone to microbial spoilage, drying facilitates its storage and also handling. Drying of oregano resulted in considerable increase in the recovery of TPC in comparison to extracts from fresh plant material, however the antioxidant activity against linoleic acid oxidation was not affected and the DPPH radical scavenging ability was reduced [89]. A study among different drying methods revealed that air-dried extracts of oregano had significantly higher rosmarinic acid content than the vacuum oven-dried, the freeze-dried and the fresh samples [90]. Additionally, grinding of the herb increases the contact surface area and shortens the diffusion path, and, thereby, increases the extraction rate. Thus, a particle size of $<315 \mu \mathrm{m}$ strongly affected the initial rate of extraction, and, consequently, decreased to more than half the time needed for the total phenolic extraction. However, the final recovery was not affected by the particle size [64]. Majeed et al. [78] observed that particle size had a smaller effect than methanol-in-water concentration, solid-to-liquid ratio, and extraction time, but still a higher TPC recovery was obtained as particle size decreased from 110 to $20 \mu \mathrm{m}$.

The standardization of extracts obtained from oregano is investigated in order to facilitate their integration into food, beverages, food preservatives, cosmetics, dietary sup- 
plements, pharmaceuticals, and nutraceuticals. Formulations such as liquids, powders, pastes, and gels are currently in the market [91]. Powders are mostly used as ingredients in dietary supplements such as tablets and capsules. These formulations are also intended to protect the sensitive oregano extract compounds against oxidation. Additionally, the encapsulation of the extracts in water-soluble microcapsules can protect physically the active components during storage and, moreover, during the digestion process, favoring the maintenance of their antioxidant activity [92]. Oregano extracts were effectively microencapsulated in maltodextrin and the concentration of phenolics and flavonoids was higher when $10 \%$ instead of $15 \%$ maltodextrin was used. The powders formed by encapsulation of the extract obtained by hot extraction were 1.6 times richer in total phenolics than those obtained by cold extraction [35]. Another potent use of oregano extracts is in active packaging, where it can be incorporated or coated in edible or non-edible packaging material. Together with tea and rosemary extracts, oregano extract is one of the most extensively examined for this application, with very positive results $[52,93]$.

\section{Pink Savory}

Pink savory (Satureja thymbra) is a member of the genus Satureja, which consists of about 200 species, widely distributed in the Mediterranean area, Asia, and North America, regularly found in sunny, dry, rocky habitats [94]. S. thymbra extracts possess several components with antioxidant and pharmacological activities [95-97]. Additionally, the plant showed antiviral potential against SARS-CoV and HSV-1 infection [96,98]. S. thymbra $\mathrm{EO}$ is especially rich in oxygenated monoterpenes. Among these, the best known, are thymol and carvacrol.

The extracts of S. thymbra are rich in phenolic acids and flavonoid compounds (Table S1). Rosmarinic acid is the main phenolic acid, followed by salvianolic acid A and lithospermic acid, well-known caffeic acid derivatives [99]. Luteolin, apigenin, eriodictyol, and naringenin, together with ethers of luteolin and apigenin are the main flavonoids identified, while aromadendrin, taxifolin and ladanein have been also reported $[79,100,101]$. Apigenin7-O-glucoside is a common glycoside in Lamiaceae, which has been identified by numerous researchers [73,102,103]. Tsimogiannis et al. [101] identified luteolin-7-O-rutinoside in the ethanol extract of $S$. thymbra. This compound has been also identified in $S$. hortensis and S. montana $[102,104]$.

Research efforts for the extraction of antioxidant compounds from S. thymbra are limited (Table 3). Sequential Soxhlet extraction with ethyl acetate, and ethanol, of the by-product derived through water-steam distillation to recover the EO, indicated a TPC recovery of 154 and $289 \mathrm{mg} \mathrm{GAE} / \mathrm{g}$ dry plant, respectively, while the water remaining in the distillatory had an additional $249 \mathrm{mg}$ GAE/g dry plant. All the extracts showed high DPPH radical scavenging capacity, following the order ethanol extract $>$ water $>$ ethyl acetate extract [101]. Among the byproducts of the EO hydrodistillation from several Lamiaceae family plants, namely $S$. thymbra, O. dictamnus, O. hirtum, O. onites, and $R$. officinalis, subjected to mild alkaline extraction, $S$. thymbra extracts showed the best antiradical activity, and the highest content in rosmarinic and caffeic acid [2]. These results show that the waste from $S$. thymbra EO production can be exploited for the recovery of antioxidants. 
Table 3. Extraction techniques and main results reported in literature for the recovery of phenolic compounds from pink savory.

\begin{tabular}{|c|c|c|c|c|}
\hline Solvent & Method & Measured Parameters & Main Results & Reference \\
\hline $\begin{array}{l}\text { Ethyl acetate Ethanol } \\
\text { (solid/liquid } 1 / 10, w / v)\end{array}$ & $\begin{array}{l}\text { Soxhlet successive } \\
\text { extraction }(6-8 \mathrm{~h} \text {, until the } \\
\text { extract was colorless) } \\
\text { Pretreatment: water-steam } \\
\text { EO distillation }\end{array}$ & $\begin{array}{c}\text { TPC } \\
\text { DPPH } \\
\text { Antioxidant activity in } \\
\text { palm oil and oil-in-water } \\
\text { emulsions }\end{array}$ & $\begin{array}{c}\text { The TPC content followed the order ethanol } \\
\text { extract > aqueous extract from EO } \\
\text { distillation > ethyl acetate extract. } \\
\text { Ethanol and aqueous extracts exhibited } \\
\text { good antiradical activity, ethyl acetate a } \\
\text { moderate one. } \\
\text { Ethyl acetate extract showed antioxidant } \\
\text { activity in palm oil, and ethanol extract } \\
\text { in emulsions. }\end{array}$ & [101] \\
\hline $\begin{array}{c}\text { Aqueous solution of } \\
\text { potassium hydroxide } \\
(\mathrm{KOH}), 1 \%, 3 \% \text {, and } \\
5 \%(w / v)\end{array}$ & $\begin{array}{l}\text { Maceration with stirring } \\
\text { (room temperature, } 0.5,3 \text {, } \\
\text { 6, and } 24 \mathrm{~h} \text { ) } \\
\text { Pretreatment: water-steam } \\
\text { EO distillation }\end{array}$ & $\begin{array}{c}\text { TPC } \\
\text { DPPH } \\
\text { Oxidative stability index }\end{array}$ & $\begin{array}{l}\text { High TPC and good antiradical and } \\
\text { antioxidant activity of the extracts in } 30 \mathrm{~min} \\
\text { of extraction with } \mathrm{KOH} 1 \%(w / v) . \\
\text { The increase of extraction time and } \mathrm{KOH} \\
\text { concentration caused lower TPC, } \\
\text { antioxidant, and DPPH radical scavenging } \\
\text { ability of the extracts. }\end{array}$ & [2] \\
\hline $\begin{array}{l}\text { Methanol in water } \\
70 \% \text { of Water }\end{array}$ & $\begin{array}{c}\mathrm{UAE} \text { (bath, less than } 30^{\circ} \mathrm{C} \text {, } \\
20 \mathrm{~min} \text { ) }\end{array}$ & $\begin{array}{l}\text { HPLC } \\
\text { DPPH } \\
\text { FRAP } \\
\text { ABTS } \\
\text { TPC }\end{array}$ & $\begin{array}{l}\text { A reversed phase HPLC method has been } \\
\text { developed for the determination of } \\
24 \text { phenolic compounds in five aromatic } \\
\text { plants of the Lamiaceae family. Methanol } \\
70 \% \text { was more effective than water. }\end{array}$ & [79] \\
\hline $\begin{array}{l}\text { Methanol (solid/liquid } \\
1 / 33.3, w / v)\end{array}$ & $\begin{array}{l}\text { Heat reflux extraction } \\
\quad \text { (water bath, } 1 \mathrm{~h} \text { ) }\end{array}$ & HPLC & $\begin{array}{l}\text { Isolation, qualification, and quantification of } \\
\text { free phenolic acids in plant material. } \\
\text { Removal of interfering compounds } \\
\text { (chlorophyll, waxes, and polyphenols) by } \\
\text { means of a solid phase extraction clean-up } \\
\text { on an octadecyl sorbent and anion } \\
\text { exchange resin. }\end{array}$ & [105] \\
\hline $\begin{array}{l}\text { Glycerol-based } \\
\text { ionic liquids }\end{array}$ & $\begin{array}{l}\text { Maceration with stirring } \\
(600 \mathrm{rpm}) \text {, at } 50^{\circ} \mathrm{C} \text { for } \\
200 \mathrm{~min}\end{array}$ & $\begin{array}{l}\text { HPLC } \\
\text { TPC } \\
\text { DPPH } \\
\text { FRAP }\end{array}$ & $\begin{array}{l}\text { Optimum water concentration } 54.8-63.8 \% \\
(v / v) \text { and } \mathrm{s} / 11 / 30-1 / 36, w / v \text {. } \\
\text { LTTMs displayed anti-Arrhenius kinetics } \\
\text { over a temperature ranging from } 40 \text { to } 80^{\circ} \mathrm{C} \text {, } \\
\text { evidencing peculiar extraction behavior. }\end{array}$ & [106] \\
\hline
\end{tabular}

ABTS: 2,2-azino-bis-3-ethylbenzothiazoline-6-sulfonic acid radical, DPPH: 1,1-diphenyl-2-picrylhydrazyl radical, EO: essential oil, FRAP: ferric reducing antioxidant power, TPC: total phenolic content, UAE: ultrasound assisted extraction.

Özkan and Özcan [107] used mild acidic hydrolysis to release bound phenolic compounds during the extraction with mixtures of organic solvents with water. Thus, they compared four different solvent mixtures (ethanol:water:acetic acid (95:4.5:0.5), methanol:water:acetic acid (95:4.5:0.5), acetone:water:acetic acid (95:4.5:0.5), and methanol:acetone:water:acetic acid (55:40:4.5:0.5)) using either Soxhlet extraction or UAE (bath). The highest TPC and antioxidant properties were determined in the extract obtained using ethanol:water:acetic acid (95:4.5:0.5) in Soxhlet. The extracts showed strong antioxidant activity as measured by the phosphomolybdenum method in vitro, by their capacity to scavenge DPPH radical, and by their ability to decrease the rate of peroxide formation in olive oil in comparison to synthetic antioxidants, like BHA and BHT. Additionally, extraction by $70 \%$ methanol in water proved much more effective than water for the recovery of phenolic acids and flavonoids. The extraction was performed in an ultrasound bath for $20 \mathrm{~min}$, at $30{ }^{\circ} \mathrm{C}$ and the predominant phenolic acid was rosmarinic, representing $88 \%$ of the total phenolic acids, while naringenin was the predominant flavonoid, representing $91 \%$ of the total flavonoids [79]. Rosmarinic acid was found in higher concentrations in Satureja species and R. officinalis compared to other Lamiaceae family plants [105].

Recently, three glycerol-based eutectic solvents were tested for their efficiency to recover polyphenolic antioxidants from $S$. thymbra [106]. The process was optimized by Box-Behnken design and response surface methodology (RSM) with respect to water concentration (optimum values 54.8-63.8\%, v/v) and solid/liquid (optimum values $1 / 30-1 / 36 \mathrm{~g} / \mathrm{mL}$ ). Yields approximated $140 \mathrm{mg} \mathrm{GAE} / \mathrm{g}$ dry weight, and the chromatographic analysis showed the presence of several phenolic substances, tentatively ascribed 
to rosmarinic acid, apigenin, luteolin, and quercetin derivatives. Although none of the eutectic mixtures showed selectivity, the mixture composed of glycerol and trisodium citrate was proposed for further research by the authors.

Ethyl acetate and ethanol extracts of $S$. thymbra proved effective antioxidants against olive oil or vegetable oil oxidation and also retarded significantly the oxidation of emulsions $[101,107,108]$. Additionally, the ethanol extract combined with the plant EO exhibited antioxidant and antimicrobial activity when added into a carboxyl-methyl-cellulose edible film that was used for fresh gilthead seabream fillets, by reducing the peroxide values by approximately threefold and eliminating the formation of secondary oxidation products [99]. Additionally, S. thymbra extracts proved effective when coated on non-edible film used as active packaging for snacks. More specifically, incorporated in the packaging they protected the snacks better than adding them to the frying oil or to the fried product [109]. These results show that $S$. thymbra is one of the most potent sources of antioxidant and bioactive compounds, while purification and formulation of its extracts need further research.

\section{Lemon Balm}

Lemon balm (Melissa officinalis L.) is a common plant of the Lamiaceae family, native to Europe, Central Asia, and Iran, but now growing around the word. It is used as flavoring in confectionery, teas, and certain foods, and in traditional medicine. Its EO is used as a perfume ingredient and in aromatherapy [110]. Additionally, the plant is used to attract bees, as it flourishes in summer, with white small flowers full of nectar, hence the name melissa, meaning bee in Greek. Several studies have demonstrated the antioxidant plus various biological activities, such as antimicrobial, anti-inflammatory, antiplatelet, anticancer, antidepressant, anxiolytic, hypolipidemic, etc. [79,110-116]. The main constituents associated with these activities are triterpenoid acids, phenolic acids, and flavonoids.

The main identified triterpenoids are ursolic and oleanolic acid and their derivatives $[114,117]$. Rosmarinic acid was the main phenolic acid in M. officinalis extracts, amounting to $1.50-6.8 \%$ of the dry leaves of the plant [111,113,118-120], and it was associated to the antioxidant properties of these extracts [114,117,121]. Additionally, rosmarinic acid showed antimicrobial activity, contrary to the triterpene derivatives that showed very low or no antimicrobial activity [114]. Compared to other Lamiaceae herbs, M. officinalis presents a very high content of rosmarinic acid [122,123].

Table 4 presents the main reported results about the solvents and extraction methods that have been used for the recovery of the plant bioactive components. Awad et al. [113] performed successive extractions with hexane, ethyl acetate, methanol, and water (solid/liquid, $1 / 10, w / v)$. Hexane extract showed no effect, while methanol extract exhibited the highest activity towards the inhibition of the rat brain $\gamma$-aminobutyric acid transmitase (GABA-T), an enzyme targeted for the therapy of neurological disorders, like anxiety and epilepsy. The extract was rich in rosmarinic acid, while ursolic, oleanolic, caffeic, and other not identified hydrocinnamic acids were present, and might exhibit additive or synergistic actions with rosmarinic acid. Rosmarinic acid was the most abundant phenolic compound in water infusions, alcohol, or alcohol-water extracts, according to several researchers, while salvianolic acids, lithospermic acid, caffeic acid, and their derivatives were also reported [79,105,119,123-127]. Gentisic, gallic, and small amounts of $p$-coumaric, protocatechuic, and chicoric acids were also detected [105,116,119,126-128]. Luteolin, luteolin-7-O- $\beta$-glucoside, and luteolin-3'O-glucuronide were among the main reported flavonoids of the herb [114,117,124-126]. Quercetin, myricetin, epigallocatechin, and rutin were also detected in ethanol or water extracts $[66,79,116,129]$. The identified compounds reported in literature are presented in Table S1. 
Table 4. Techniques and main results reported in literature for the extraction of phenolic compounds from lemon balm.

\begin{tabular}{|c|c|c|c|c|}
\hline Solvent & Method & Measured Parameters & Main Results & Reference \\
\hline $\begin{array}{c}\text { Ethanol } \\
\text { (Solid/liquid } \\
1 / 4-1 / 10, w / v)\end{array}$ & $\begin{array}{l}\text { CSE } \\
\text { temperature } 0-80{ }^{\circ} \mathrm{C}, \\
\text { particle size } 200-250, \\
250-315,315-400 \mu \mathrm{m}\end{array}$ & $\begin{array}{c}\text { CA } \\
\text { UA } \\
\text { OA } \\
\text { Extraction yield }\end{array}$ & $\begin{array}{l}\text { Extraction was governed by internal mass } \\
\text { transfer (diffusion coefficients according to } \\
\text { Fick's 2nd low were determined) } \\
\text { Yield increased with decreasing particle size } \\
\text { and solid-to-liquid ratio. }\end{array}$ & [130] \\
\hline $\begin{array}{l}\text { Ethanol, methanol, } \\
\text { acetone or acetonitrile, all } \\
\text { 30\% in water } \\
\text { Water } \\
\text { Ethanol } 15-96 \% \\
\text { Solid/liquid } 1 / 500, w / v\end{array}$ & UAE $10 \mathrm{~min}$ & $\begin{array}{l}\text { RA } \\
\text { CAF }\end{array}$ & $\begin{array}{l}\text { All } 30 \% \text { mixtures showed similar RA recovery } \\
20 \% \text { higher than pure water. } \\
30 \text { and } 60 \% \text { ethanol in water showed the } \\
\text { highest recovery of both acids. }\end{array}$ & [131] \\
\hline $\begin{array}{l}\text { Methanol in water } 40-80 \% \\
\text { Solid/liquid } 1 / 20, w / v\end{array}$ & $\begin{array}{c}\text { CSE } \\
\left(25-55^{\circ} \mathrm{C}, \text { extraction time }\right. \\
30-90 \mathrm{~min})\end{array}$ & RA & $\begin{array}{l}\text { The optimum conditions determined by RSM } \\
\text { were methanol concentration } 59 \%, v / v \text {, at } \\
55^{\circ} \mathrm{C} \text {, for } 65 \text { min and gave RA yield } 4.6 \% \text { on } \\
\text { dry leaves. }\end{array}$ & [132] \\
\hline $\begin{array}{c}\text { Methanol in water } \\
\text { Methanol in water (pH 2.5) } \\
\text { Ethanol in water } \\
\text { Ethanol on water (pH 2.5) } \\
\text { Water } \\
\text { Solid/liquid } 1 / 50,1 / 100 \\
1 / 150, w / v\end{array}$ & $\begin{array}{c}\text { CSE, } \\
\text { UAE (bath) } \\
\left(25^{\circ} \mathrm{C}, 5-20 \mathrm{~min}\right)\end{array}$ & $\begin{array}{l}\text { RA } \\
\text { CAF } \\
\text { ProtCa }\end{array}$ & $\begin{array}{l}\text { UAE was more effective than CSE at the same } \\
\text { time. RA extraction was slightly higher with } \\
\text { acidified mixtures. Methanol } 60 \% \text {, at a } \\
\text { solid-to-liquid ratio } 1: 100, \text { by } 3 \text { successive } \\
\text { extractions of } 10 \text { min each, recovered } \\
\text { quantitatively all phenolic acids. }\end{array}$ & [119] \\
\hline $\begin{array}{c}\text { Methanol in water } 0-100 \% \\
\text { Ethanol in water } 0-100 \% \\
\text { Acidification with } \\
0.1-1.0 \% \mathrm{HCl} \\
\text { Solid /liquid } 1 / 40, w / v\end{array}$ & $\begin{array}{l}\text { Maceration under stirring } \\
(30-1140 \text { min }) \\
\text { CSE at boiling point } \\
(15-60 \text { min }) \\
\text { MAE } \\
\left(50 \text { or } 80^{\circ} \mathrm{C}, 5-30 \mathrm{~min}\right)\end{array}$ & RA & $\begin{array}{l}\text { MAE gave similar results to conventional } \\
\text { methods at shorter time ( } 5 \text { min). More than } \\
5 \text { min in MAE and } 15 \text { in CSE } \\
\text { caused degradation. } \\
\text { Ethanol:water: } \mathrm{HCl} 70: 29: 1, v / v / v \text { gave the } \\
\text { best results }\end{array}$ & [133] \\
\hline Ethanol in water $20-80 \%$ & $\begin{array}{c}\text { CSE } \\
\left(25-60^{\circ} \mathrm{C}\right)\end{array}$ & RA & $\begin{array}{l}\text { Highest RA yield at } 50 \% \text { ethanol in water. } \\
\text { Increase of temperature caused minor increase } \\
\text { in yield that was not significant above } 50^{\circ} \mathrm{C}\end{array}$ & [134] \\
\hline $\begin{array}{l}\text { Ethanol in water } 80 \% \\
\text { or } 50 \% \\
\text { Solid/liquid } 1 / 10, w / v\end{array}$ & $\begin{array}{c}\text { CSE } \\
\text { of untreated or SFE } \\
\text { treated material } \\
\left(40^{\circ} \mathrm{C} \text {, extraction time }\right. \\
110 \mathrm{~min})\end{array}$ & $\begin{array}{l}\mathrm{RA} \\
\text { Extraction yield }\end{array}$ & $\begin{array}{l}\text { Ethanol } 50 \% \text { achieved higher RA yield } \\
\text { than } 80 \% \text {. } \\
3 \text { successive extractions were needed to } \\
\text { recover RA absorbed in the wet material. } \\
\text { SFE pretreatment increased extraction rate } \\
\text { and final yield }\end{array}$ & [120] \\
\hline $\begin{array}{l}\text { Ethanol in water } 0-100 \% \\
\text { Solid/liquid } 1 / 33, w / v\end{array}$ & $\begin{array}{c}\text { CSE } \\
\left(30-90{ }^{\circ} \mathrm{C}, 30-90 \mathrm{~min}\right) \\
\text { UAE } \\
\text { (probe } 100-500 \mathrm{~W} \\
3-45 \mathrm{~min} \text { at constant } \\
\left.\text { temp.: } 30-35^{\circ} \mathrm{C}\right) \\
\text { MAE } \\
\left(60-180^{\circ} \mathrm{C}, 3-45 \mathrm{~min}\right) \\
\end{array}$ & RA & $\begin{array}{l}\text { RSM analysis showed that all studied } \\
\text { variables were significant in all methods. } \\
\text { UAE gave the highest RA yield ( } 86 \mathrm{mg} \text { RA/g } \\
\text { dry plan) under the optimum conditions ( } 40 \% \\
\text { ethanol, } 371 \mathrm{~W}, 33 \mathrm{~min}) \text {. }\end{array}$ & [135] \\
\hline $\begin{array}{c}\text { Ethanol in water } 0, \\
70,100 \% \\
\text { Solid/liquid } 1 / 10, w / v \\
\text { in MAE } \\
\text { Successive extractions } \\
\text { with hexane, acetone, } \\
\text { ethanol, water in UAE }\end{array}$ & $\begin{array}{c}\text { UAE (probe } 20 \mathrm{kHz}, \\
10 \text { min) } \\
\text { MAE (under } \mathrm{N}_{2}, 100{ }^{\circ} \mathrm{C}, \\
10 \text { min) } \\
\text { Dry extraction by grinding } \\
\text { with } \beta \text {-cyclodextrin } \\
\quad(1: 2, w / w)\end{array}$ & $\begin{array}{c}\text { HPLC } \\
\text { Extraction yield }\end{array}$ & $\begin{array}{l}\text { MAE with water showed the highest } \\
\text { extraction yield, but with } 100 \% \text { ethanol the } \\
\text { highest phenolic and RA recovery was shown. } \\
\text { UAE was less efficient and the best phenolic } \\
\text { and RA recovery was obtained with ethanol } \\
\text { and was enhanced when acetone was used in } \\
\text { a previous extraction. } \\
\text { Dry extraction was the least efficient. }\end{array}$ & [136] \\
\hline $\begin{array}{l}\text { Ethanol in water } 70 \%, 96 \% \\
\text { Solid/liquid } 1 / 10, w / v\end{array}$ & $\begin{array}{l}\operatorname{MAE}(5-15 \min , 25,40 \\
\left.60^{\circ} \mathrm{C}\right)\end{array}$ & TPC & $\begin{array}{l}70 \% \text { ethanol at } 10 \mathrm{~min} \text { and } 60^{\circ} \mathrm{C} \text { showed the } \\
\text { highest TPC recovery }\end{array}$ & [137] \\
\hline $\begin{array}{c}\text { Ethanol } \\
\text { Water } \\
\text { Solid/liquid } 1 / 20, w / v\end{array}$ & $\begin{array}{l}\text { EAE (cellulose, } \beta \text {-xylanase, } \\
\left.\text { pectinase, } 50^{\circ} \mathrm{C}, 2 \mathrm{~h}, \mathrm{pH} 5\right) \\
\text { ASE }\left(150^{\circ} \mathrm{C}, 20 \mathrm{~min}\right)\end{array}$ & $\begin{array}{c}\text { TPC } \\
\text { LC-MS/MS } \\
\text { DPPH } \\
\text { TEAC (ABTS) }\end{array}$ & $\begin{array}{l}\text { ASE showed the highest TPC yield and } \\
\text { antioxidant activity with water being more } \\
\text { effective than ethanol. EAE with a } \\
\text { combination of all enzymes gave better results } \\
\text { than non-enzymatic extraction (pH 5). }\end{array}$ & [127] \\
\hline
\end{tabular}


Table 4. Cont.

\begin{tabular}{|c|c|c|c|c|}
\hline Solvent & Method & Measured Parameters & Main Results & Reference \\
\hline $\begin{array}{c}\text { Water } \\
\text { Solid/liquid } 1 / 20, w / v\end{array}$ & $\begin{array}{l}\mathrm{CSE}\left(40-100^{\circ} \mathrm{C},\right. \\
5-120 \mathrm{~min})\end{array}$ & $\begin{array}{l}\text { TPC } \\
\text { DPPH } \\
\text { ABTS }\end{array}$ & $\begin{array}{l}\text { Optimization by RSM. Temperature and } \\
\text { temperature-time interaction were significant. } \\
\text { Optimum results at } 100{ }^{\circ} \mathrm{C} \text { for } 120 \mathrm{~min}\end{array}$ & [138] \\
\hline $\begin{array}{l}\text { Water } \\
\text { Solid/liquid } 1 / 10,1 / 20 \\
1 / 30, w / v\end{array}$ & $\begin{array}{c}\text { CSE } \\
\left(97^{\circ} \mathrm{C}, 5-30 \mathrm{~min}\right) \\
\text { UAE (probe at } 150 \text { or } \\
240 \mathrm{~W}, 5-30 \mathrm{~min}, \text { and } \\
\left.\text { constant temp } 40^{\circ} \mathrm{C}\right) \\
\text { MAE } \\
\left(97^{\circ} \mathrm{C}, 5-20 \mathrm{~min}\right) \\
\text { Maceration } \\
\left(40^{\circ} \mathrm{C}, 24 \mathrm{~h}\right)\end{array}$ & $\mathrm{TPC}$ & $\begin{array}{l}\text { Phenolics recovery increased as } \\
\text { solid-to-liquid decreased. } \\
\text { MAE showed the highest TPC recovery } \\
\text { (146 mg GAE/g dry plant, at } 5 \text { min) and UAE } \\
\text { the lowest (106 mg GAE/g dry plant, at } \\
20 \text { min) CSE yield amounted to } 120 \mathrm{mg} \\
\text { GAE/g dry plant, at } 30 \text { min but the extract } \\
\text { showed similar DPPH scavenging to MAE. } \\
\text { Maceration showed similar results to UAE. }\end{array}$ & [139] \\
\hline
\end{tabular}

ABTS: 2,2-azino-bis-3-ethylbenzothiazoline-6-sulfonic acid radical, ASE: accelerated solvent extraction, CA: carnosic acid, CAF: caffeic acid, CSE: conventional solvent extraction, DPPH: 1,1-diphenyl-2-picrylhydrazyl radical, MAE: microwave assisted extraction, OA: oleanolic acid, ProtCa: protocatechuic acid, RA: rosmarinic acid, SFE: supercritical fluid extraction, TPC: total phenolic content, UA: ursolic acid, UAE: ultrasound assisted extraction.

Since the phenolic compounds of M. officinalis comprise mostly phenolic acids and flavonoid glycosides, acetone, and especially hexane extracted very low amounts, contrary to ethanol that presented high TPC recovery and antioxidant activity of the extracts [140]. Aqueous alcohol mixtures were further examined by several researchers. Aqueous ethanol and water were much more effective than pure ethanol in the extraction of phenolic compounds [141]. Methanol-water, ethanol-water, and water were compared for their efficiency in the quantitative recovery of rosmarinic acid. Both alcohol mixtures were more efficient than water and the recovery increased when the mixtures were acidified $[119,133]$. Caffeic acid and protocatechuic acid were also determined in the extracts. Three successive extraction steps with methanol $60 \%$ in water solution, at a solid /liquid of $1 / 100, \mathrm{~g} / \mathrm{mL}$, for 10 min each, by the use of $\mathrm{UAE}$ at $25^{\circ} \mathrm{C}$, were sufficient for the quantitative recovery of all acids [119]. Successive extractions are necessary because a large amount of the extract (about $40 \%$ of the initial solvent mass) is retained in the herb [120]. Sik et al. [133], using lemon balm and other herbs, reported either $70 \%$ or $50 \%$, both of them acidified with $1 \% \mathrm{HCl}$, as optimum methanol concentration in aqueous solutions, depending on the herb and extraction method. Optimization of rosmarinic acid extraction with methanol in water mixtures, by RSM, revealed $59 \%$ methanol as the optimum concentration, while increase above $65 \%$ resulted in lower yield [132]. Similarly, testing different ethanol in water concentrations the highest rosmarinic acid yield was obtained with $50 \%[120,133,134]$, or $70 \%$ if acidified with $1 \% \mathrm{HCl}$ [133], while 30-60\% gave the highest extraction yield for both rosmarinic and caffeic acids [131]. Rosmarinic, caffeic and other phenolic acids are soluble in both water and aqueous alcohol solutions. Thus, the higher effectiveness of the latter in quantitative phenolic acids extraction might be attributed to a better penetration in the plant matrix. Rosmarinic acid and other extracted antioxidants can be separated from the ethanolwater mixtures by nanofiltration, instead of evaporation, and the permeate can be recycled, with apparent economic benefits [120]. The procedure has been successfully tested in both lemon balm and rosemary extracts and the retentate maintains its antioxidant capacity and can be used directly as preservative or functional ingredient in foods, cosmetics, or medicines, as it presents a high concentration of active compounds [120,142].

Optimization of the water extraction conditions resulted in $100{ }^{\circ} \mathrm{C}$ for $120 \mathrm{~min}$ as the optimum conditions for TPC recovery and antiradical (DPPH, $\left.\mathrm{ABTS}^{+}\right)$activity of the extracts [138]. Hydrolysis with $0.2 \mathrm{M}$ hydrochloric acid increased the TPC content of the extract, and the FRAP, indicating that glycosylated forms might have been hydrolyzed to the respective aglycons that present higher antioxidant power. The content in rosmarinic acid was not significantly affected by hydrolysis, on the contrary the content in caffeic acid was increased by approximately 10 -fold [143]. 
During CSE with ethanol-water mixtures, the yield increased rapidly at the beginning, slowing down towards the end of the extraction $[120,130,134]$. The kinetic study, based on the extraction yield, indicated that after an initial spontaneous extraction, a fast and a slow extraction stage followed, obeying to non-steady diffusion as described by the 2nd Fick law [130], similarly to the observations for rosemary and oregano [21,64]. Grinding of the raw material to smaller particle size, and increase of solvent in the mixture had a minor effect on the fast extraction stage but increased the rate of the slow stage and the final yield. Extraction temperature $\left(0-80^{\circ} \mathrm{C}\right)$ had a variable effect on the detected phenolic acids (carnosic, ursolic, and oleanolic), possibly due to the very low detectable concentrations and the sensitivity of these compounds to higher temperatures [130]. Another study demonstrated that the increase of temperature from 25 to $50^{\circ} \mathrm{C}$ caused a minor increase in rosmarinic acid yield obtained by aqueous ethanol, while further increase to $60{ }^{\circ} \mathrm{C}$ had no effect [134]. On the contrary, a significant increase from 25 to $55^{\circ} \mathrm{C}$ was observed when aqueous methanol was used as solvent [132]. A pretreatment by SFE removed EOs, waxes, and chlorophylls and thus changed the structure of the plant material, facilitated the access of extraction solvent, and, thereby, increased the extraction rate and the rosmarinic acid yield $[120,144]$. The increase was higher when the SFE was performed at harsher conditions (higher pressure and temperature [120]. These results indicate that the conventional extraction of antioxidants can be favorably combined with the EO extraction by SFE. However, longer SFE duration or higher pressure may lead to the extraction of triterpenes and flavonoids and consequently decrease the antioxidant compounds in the residue [144], while the ethanol addition as modifier decreased also rosmarinic acid content in the residue [120].

UAE enhances the extraction rate and thus may decrease the extraction time to as low as $10 \mathrm{~min}[119,131]$ compared to approximately $100 \mathrm{~min}$ for CSE under agitation [120,130,134]. Considered a green extraction technique, it has been used in extraction performed in short time for analytical purposes [145]. Although UAE at room temperature with either water or ethanol $25 \%$ presented lower phenolic content in the extract and FRAP values, than the obtained in infusion preparations (10 min) and mostly decoctions (boiling for $10 \mathrm{~min}$ ), the DPPH radical scavenging capacity did not show significant differences, indicating that rosmarinic acid and other phenolic compounds reacting with DPPH were equally extracted by either method [141]. In fact, UAE performed with ethanol showed a low extraction yield but a high selectivity in the extraction of phenolic compounds and rosmarinic acid [136].

Caleja et al. [135] used experimental design and RSM to study the effect of ethanol concentration, extraction time, and temperature or power in CSE under heating, UAE, and MAE. They found that all variables were significant for the rosmarinic acid recovery. The most efficient method was UAE performed at $30-35^{\circ} \mathrm{C}$, with optimum yield $86 \mathrm{mg} / \mathrm{g}$ dry plant, at $40 \%$ ethanol, $371 \mathrm{~W}$, and $33 \mathrm{~min}$. Lower ethanol concentrations were defined as optimum for the CSE under heating and MAE (34.5\% and $25.5 \%$, respectively), with optimum temperatures 88 and $108{ }^{\circ} \mathrm{C}$, respectively, and extraction time 106 and $26 \mathrm{~min}$, respectively. According to these results MAE was the fastest extraction method but gave the lowest rosmarinic acid recovery ( $49 \mathrm{mg} / \mathrm{g}$ dry plant), and CSE the slowest method giving optimum recovery equal to $59 \mathrm{mg} / \mathrm{g}$ dry plant. Changing solid/liquid from 1/10 to $1 / 200, \mathrm{~g} / \mathrm{mL}$, increased the extraction yield, up to $153 \mathrm{mg} / \mathrm{g}$ dry plant for the optimum UAE conditions [135]. When water was used as solvent MAE obtained higher TPC and rosmarinic acid yield, compared to UAE and conventional extraction [139]. These differences may be attributed to the solvent and also the different equipment and power used by the researchers. Similarly, MAE performed at mild temperature $\left(100^{\circ} \mathrm{C}\right)$ under inert atmosphere $\left(\mathrm{N}_{2}\right)$ with either ethanol or water gave better results than UAE [136], indicating that the extraction conditions play a major role in the protection of the phenolic compounds from degradation. The highest extraction yield was obtained with water, but the highest total phenolic and rosmarinic acid yields with ethanol, which proved a much more selective solvent for the phenolic compounds. Additionally, UAE successive extractions with solvents of increasing polarity were tested, and the results indicated that 
hexane had no effect, while acetone improved the efficiency and selectivity of the following extraction with ethanol [136], probably due to removal of waxes, EO constituents, etc., and thus making the plant matrix more accessible.

Sik et al. [133] compared MAE (at 50 and $80^{\circ} \mathrm{C}$ ) with maceration under stirring and CSE at boiling temperature, with aqueous ethanol and methanol for the extraction of rosmarinic acid from lemon balm, rosemary, oregano, and other herbs. They concluded that MAE was only superior to conventional methods with respect to extraction time (5 min for MAE, compared to $15 \mathrm{~min}$ for CSE under heating, and $120 \mathrm{~min}$ for maceration). Moreover, they tested various ethanol and methanol concentrations in water and observed some differences depending on the herb and the extraction method, but generally $70 \%$ ethanol gave very good results in all cases. Radomir et al. [137] used in vitro cultured plants and examined MAE with ethanol, $70 \%$ and $96 \%$ for the recovery of total phenolic compounds. Ethanol $70 \%$ was more effective, while the recovery increased up to $10 \mathrm{~min}$ of extraction and decreased afterwards, possibly due to compounds degradation. Higher temperature, i.e., $60^{\circ} \mathrm{C}$, increased the extraction efficiency, compared to 25 and $40{ }^{\circ} \mathrm{C}$ that presented the same results.

ASE $\left(150{ }^{\circ} \mathrm{C}, 20 \mathrm{~min}\right.$ static extraction time) tripled the TPC of the extract compared to CSE $\left(50{ }^{\circ} \mathrm{C}, 2 \mathrm{~h}, \mathrm{pH}\right.$ ). Water was more effective than ethanol as a solvent in ASE (TPC: $193 \mathrm{mg}$ GAE/g extract, versus $167 \mathrm{mg} \mathrm{GAE} / \mathrm{g}$ extract) [127]. Enzymatic assisted extraction (EAE) with combinations of cellulose, $\beta$-xylanase, and pectinase was also tested, and slightly increased the TPC compared to CSE (TPC: $79 \mathrm{mg}$ GAE/g extract versus $65 \mathrm{mg}$ GAE/g extract) [127]. The antioxidant activity followed closely the TPC. These results indicate that the bonding of phenolic compounds is more sensitive to temperature than to acidity or enzymatic treatment. On the contrary, the extraction yield (g dry extract/g dry material) obtained by EAE was higher than ASE with water and non-enzymatic treatment, while ASE with ethanol presented more than 5-fold lower yield, indicating that a high amount of non-phenolic compounds was extracted by the former treatments. Consequently, ASE with ethanol provided the most selective extraction of antioxidants.

Milevskaya et al. [126] obtained the highest phenolic compounds recovery from M. officinallis and other Lamiaceae herbs, by ASE, compared to CSE under heating, UAE, or MAE.

Drying of the herb (room temperature 10 days) and storage for 6 months did not affect the TPC or the DPPH scavenging activity of the obtained extract [89]. Cultivated and especially in vitro cultured samples contained less than half TPC than the dried commercial samples, possibly due to the lower production of secondary metabolites by the plant, when grown without stress [124]. Examination of different cultivars and seeds from different companies revealed that they play an important role in TPC, phenolic profile, and antioxidant properties of the herb. Especially rosmarinic and gentisic acids were significantly affected by the cultivar [128]. Moreover, the harvesting period and time have a significant effect on the accumulation of bioactive compounds, with starting of blooming period (early June) and afternoon showing the maximum amount [146].

M. officinallis extracts have demonstrated antiradical/antioxidant properties in various systems, including $\beta$-carotene-linoleic acid bleaching, superoxide anion, nitric oxide and DPPH radicals scavenging, and ferric chelation, indicating that they have the potential to prevent oxidative damage in vivo and pathological disorders [145,147]. Additionally, they proved effective antioxidants for lipid protection in oils and emulsions [112]. Water extracts, rich in phenolic compounds were effectively encapsulated in maltodextrin, by spray drying [138]. However, there is a need for further study towards the purification and formulation of these extracts in order to be exploited commercially.

\section{St. John's Wort}

St John's wort (Hypericum perforatum) belongs to the Hypericaceae family and is abundant in Europe, part of Asia, North America, and Australia. In addition to antioxidant compounds, St. John's wort extracts possess several components with pharmacological 
activities [148-150]. The plant extracts are traditionally used against mild depression and for the treatment of infected wounds. Most of the pharmacological activities, and especially the antidepressive activity, were initially attributed to hypericins but recent studies revealed that hyperforins and the flavonoid components contribute to this activity, possibly through synergistic actions $[148,151,152]$. However, although the plant is included in several Pharmacopeia, both FDA and EU council consider it a dietary supplement, and not a drug [152,153]. Overall, the bioactive constituents of the plant may be classified in three main categories, phloroglucinols (mainly hyperforin and adhyperforin, Figure 1a), naphtodianthrones (primarily represented by hypericin and pseudohypericin, Figure 1a), and flavonoids (quercetin, quercetin glucosides, kaempferol, etc., Figure 1b). It is the only species that contains hyperforin as one of its main ingredients [154]. Additionally, the plant contains phenolic acids, such as chlorogenic, and carotenoids, while it is rather poor in EO $(0.05-0.9 \%)[148,155]$. The compounds, identified in higher quantities in the plant, together with their yields by several extraction procedures, are presented in Table 5. Additionally, the buds and flowers of the plant contain some protopigments, i.e., protohypericin and protopseudohypericin, which are transformed to hypericin and pseudohypericin under the exposure to light [156].

Table 5. Extraction yields of the major constituents of St. John's wort reported by several investigators.

\begin{tabular}{|c|c|c|c|c|c|}
\hline \multirow{2}{*}{ Compound } & \multicolumn{5}{|c|}{ Yield (mg/g on Dry Plant Basis) Reported by Reference } \\
\hline & [157] & {$[158]^{\mathrm{c}}$} & {$[159]^{d}$} & {$[160]^{\mathrm{e}}$} & {$[161]^{\mathrm{f}}$} \\
\hline Hyperforin & $10.8-24.1^{\mathrm{a}}$ & 1.5 & 0.7 & 13.0 & n.d \\
\hline Adhyperforin & $0.4-3.2^{\mathrm{a}}$ & n.m. & n.m & 2.0 & n.d \\
\hline Hypericin & $1.5-2.6^{\mathrm{b}}$ & 0.2 & 0.4 & 0.3 & 0.3 \\
\hline Pseudohypericin & $0.8-1.4^{\mathrm{a}}$ & 0.5 & 0.5 & 0.5 & 1.0 \\
\hline Biapigenin & $7.1^{b}$ & & 1.4 & 0.1 & 0.6 \\
\hline Quercetin & $8.1^{\mathrm{b}}$ & & 1.1 & 3.3 & 2.3 \\
\hline Quercitrin & $0.9-6.5^{\mathrm{a}}$ & 0.8 & 1.2 & 1.4 & 2.7 \\
\hline Isoquercitrin & $1.2-7.0^{\mathrm{a}}$ & & 3.3 & 2.6 & 5.2 \\
\hline Hyperoside & $7.4-29.5^{\mathrm{a}}$ & 2.8 & 6.2 & 7.3 & 16.3 \\
\hline Rutin & $7.8^{b}$ & 3.0 & 0 & 13.0 & 21.4 \\
\hline Chlorogenic acid & $1.6^{\mathrm{b}}$ & & 5.4 & 1.1 & 6.8 \\
\hline
\end{tabular}

a: sonication with methanol at ambient temperature, ${ }^{b}$ : Soxhlet extraction with ethanol, ${ }^{\mathrm{c}}$ : direct sonication with methanol, ${ }^{\mathrm{d}}$ : repeated (24 h each) methanol extractions at dark, ${ }^{\mathrm{e}}$ : ASE $\left(120^{\circ} \mathrm{C}, 100-150 \mathrm{~atm}\right)$ with $70 \%$ ethanol in water (solid/liquid 1/50), f: Soxhlet extraction with methanol.

Hyperforin is the main phloroglucinol component of the plant and is considered as a potent antidepressant, remedy against inflammatory skin diseases of wounds, and antimicrobial agent [148,162-164]. It is a lipophilic compound and can be recovered by nonpolar solvents, like diethyl ether, petroleum ether, and hexane $[157,164,165]$. Nevertheless, n-hexane presented very low recovery during long lasting Soxhlet extraction because hyperforin is strongly degradable in aprotic solvents [166]. Thus, it should be stabilized during and after the extraction by the addition of ascorbic palmitate or a mixture of ascorbic and citric acids, via transformation to weak salt by dicyclohexylamine base, or through transfer to methanol [164]. Moreover, it is unstable under heat, air, and light, indicating ambient temperature, absence of light and air as the best extraction and storage conditions, and as necessary precautions of analysis $[159,165,167]$. Furthermore, a $20 \%$ loss of the compound was observed when exposing the plant flowers to light for $2 \mathrm{~h}$, while drying under dark had no effect [167].

Additionally, to non-polar solvents, methanol and ethanol have been proposed for the quantitative extraction of phloroglucinols (hyperforin and adhyperforin), though the extracts are also rich in hypericins [167]. Hypericins cause photosensitivity and are not desirable components in some cosmetic or pharmaceutical applications of hyperforin. For example, hypericin-free but hyperforin-rich products are proposed against inflammatory skin diseases, such as atopic dermatitis [168]. Therefore, the respective commercially 
available extracts for cosmetics are usually standardized according to their hyperforins content and to the absence of hypericins.

A hypericin-free extract of hyperforins can be obtained by supercritical or subcritical $\mathrm{CO}_{2}\left(70 \mathrm{~atm}, 22^{\circ} \mathrm{C}\right)$. The latter proved the most selective solvent for hyperforins that amounted to $60 \%$ of the total extract weight [169]. Supercritical $\mathrm{CO}_{2}$ at $450 \mathrm{~atm}$ and $40{ }^{\circ} \mathrm{C}$ resulted in a recovery of $24.0 \mathrm{mg} / \mathrm{g}$ dry plant material [166], while at $100 \mathrm{~atm}$ and $40{ }^{\circ} \mathrm{C}$ a yield amounting to 19.0 and $2.9 \mathrm{mg} / \mathrm{g}$ dry plant material for hyperforin and adhyperforin, respectively, was reported [170]. In general, higher $\mathrm{CO}_{2}$ density, which was obtained by higher pressure and lower temperature, resulted in higher hyperforin yield [170,171]. Trying to optimize SFE conditions, Cui and Ang [163] reported that $380 \mathrm{~atm}$ at $50{ }^{\circ} \mathrm{C}$ presented the best results, and more than $95 \%$ of hyperforin and adhyperforin were extracted after $10 \mathrm{~min}$ static, followed by $1.5 \mathrm{~h}$ dynamic extraction, while the use of a co-solvent did not improve the results, on the contrary increased polar impurities. Alternatively, pretreatment of the plant material $\left(100 \mathrm{~atm}\right.$ at $40{ }^{\circ} \mathrm{C}$ for $2 \mathrm{~h}$ ) without flowing of supercritical $\mathrm{CO}_{2}$, followed by extraction with methanol in an ultrasonic bath presented appreciably higher yield than that obtained by UAE without pretreatment (18.4 versus $13.3 \mathrm{mg} / \mathrm{g}$ dry plant material, and 2.3 versus $1.6 \mathrm{mg} / \mathrm{g}$ dry plant material for hyperforin and adhyperforin, respectively) due to penetration of $\mathrm{CO}_{2}$ in the tissue structure that allowed better contact with methanol. The obtained extract contained also hypericin, and more specifically it was recovered in higher yield from the pretreated material, i.e., $1.5 \mathrm{mg} / \mathrm{g}$ dry plant material versus $0.8 \mathrm{mg} / \mathrm{g}$ dry plant material from the non-treated material [170].

In general, hypericin, flavonoids, and phenolic acids of the plant are quantitatively recovered by more polar solvents (i.e., methanol, ethanol, or aqueous solutions) at elevated temperature. Liu et al. [172] comparing polar and non-polar solvents (water, ethanol, acetone, chloroform, and hexane) found that mixtures of ethanol with acetone were the most effective, and the optimum conditions for the extraction of flavonoids and hypericin were $44-69 \%$ ethanol in acetone, for $5.3-5.9 \mathrm{~h}$, at $55^{\circ} \mathrm{C}$, under stirring. However, they mentioned that high temperature increases the extraction yield but leads to hypericin degradation. Similarly, ethanol proved the most efficient in hypericin extraction (yield $1.2 \mathrm{mg} / \mathrm{g}$, dry basis) compared to 2-propanol and ethyl acetate, while n-hexane extracted very low quantity (Soxhlet extraction) [166]. Ethanol was also reported as the best solvent for the efficient quantification of hypericins and their presumed precursors (emodin, skyrin, and skyrin derivatives), while acetone and $80 \%$ methanol were also potent extractants [173]. Acetone was more effective for the extraction of hypericins, compared to methanol and tetrahydrofuran, opposed to flavonoids and phenolic acids that were more quantitatively extracted by the latter [161]. In the same study hexane and methylene chloride proved ineffective.

As hypericins were considered the main components providing the pharmacological activities of the plant, several researchers focused on their separation and purification from the crude hydroalcoholic extracts. A liquid-liquid extraction technique followed by preparative column chromatography resulted in a product with $98 \%$ purity, while the remaining aqueous extract was rich in flavonoids and could be used as a potent antioxidant [174]. Various chromatographic techniques have been also tested [175].

With regards to the extraction methods, the maximum recovery of hypericin was obtained through digestion or Soxhlet extraction with methanol [157]. Additionally, the flavonoids yield was approximately duplicated by Soxhlet extraction with either methanol or ethanol, compared to UAE or stirring at ambient temperature [157]. Smercerovic et al. [158] compared different extraction methods by using methanol (at solid/liquid 1/20) and found UAE with direct sonication $(60 \mathrm{~W}, 1 \mathrm{~h})$ more effective than Soxhlet extraction $(24 \mathrm{~h})$, ASE $\left(40^{\circ} \mathrm{C}, 100 \mathrm{~atm}\right)$, or maceration $(24 \mathrm{~h})$. However, the obtained recoveries of the active compounds were considerably lower than those reported by Avato et al. [157] (Table 5). Different extraction methods were also examined by Williams et al. [161], by using methanol as solvent, and quantifying flavonoids, hypericins but not hyperforins. Soxhlet extraction $(24 \mathrm{~h})$ presented better results than indirect $\operatorname{UAE}\left(60^{\circ} \mathrm{C}, 2 \mathrm{~h}\right)$ and the latter better than ASE $\left(60^{\circ} \mathrm{C}, 152 \mathrm{~atm}\right.$, $0.5 \mathrm{~h}$ ). However, increase of ASE temperature to $150^{\circ} \mathrm{C}$ increased substantially the yield of 
all components, except quercetin that was probably degraded above $100{ }^{\circ} \mathrm{C}$, while repeated extractions (6-8) with fresh solvent gave results comparable to solvent extraction. The authors commented that longer extraction times and higher temperatures favor the extraction of most components. Another study [160] with $70 \%$ ethanol in water at a solid/liquid 1/50, g/mL, concluded that $\operatorname{ASE}\left(120^{\circ} \mathrm{C}, 100-150 \mathrm{~atm}, 20 \mathrm{~min}\right)$ and $\operatorname{MAE}\left(75^{\circ} \mathrm{C}, 30 \mathrm{~min}\right)$ provided higher recovery (by 20-35\%) of the bioactive components compared to extraction with indirect UAE $\left(25^{\circ} \mathrm{C}, 30 \mathrm{~min}\right.$ ), and static extraction under heating (solvent boiling point, $90 \mathrm{~min}$ ). However, decreasing the solid to liquid ratio to $1 / 100$, improved considerably the yield of the static extraction under heating.

The contradictory conclusions, presented above, about the effectiveness of the different extraction methods are probably due to different apparatus and mostly to different temperature, time, and solid/solvent used by each research team. In a study of quercetin (that was the most abundant component) extraction optimization, by using aqueous methanol under indirect $\mathrm{UAE}$, the optimum conditions were determined as methanol concentration $77 \%$, acidified with $\mathrm{HCl}(1.2 \mathrm{M})$, extraction temperature $67^{\circ} \mathrm{C}$, extraction time $67 \mathrm{~min}$, and the obtained quercetin yield amounted to $11.1 \mathrm{mg} / \mathrm{g}$ dry plant [176]. In the obtained extracts no rutin was detected, possibly because it was hydrolyzed to quercetin under the acidic conditions used. The extraction methods and parameters and the main results are summarized in Table 6. Additionally, a review about the reported extraction methods and the respective compound recoveries is provided by Milevskaya et al. [74].

Comparing plants from different districts, it was evident that the consistency varied widely [157]. For example, the content of flavonoids and phenolic acids varied from 13.7 to $35.9 \mathrm{mg} / \mathrm{g}$ dry plant, and that of phloroglucinols and naphthodianthrones from 4.6 to 13.4 [160]. The collection period affects the consistency, and the plant collected at the end of the flowering period contains higher quantities of phloroglucinols, while the plant collected at the beginning of the flowering period exhibited higher hypericins content $[151,166]$. 
Table 6. Techniques and main results reported in literature for the extraction of phenolic compounds from St. John's wort.

\begin{tabular}{|c|c|c|c|}
\hline Extraction Method and Parameters & Analysis & Main Results & Reference \\
\hline $\begin{array}{l}\text { CSE }(1 \mathrm{~g} / 25 \mathrm{~mL} \text { under stirring }) \\
\text { Phase I: Water, ethanol } 50 \% \text { in water, ethanol, ethanol } 50 \% \text { in } \\
\text { acetone, acetone, chloroform, hexane } \\
\text { Phase II: ethanol in acetone } 20-80 \%, 23-55^{\circ} \mathrm{C}, 4.5-7.5 \mathrm{~h}\end{array}$ & HPLC & $\begin{array}{l}\text { Phase I: ethanol, ethanol } 50 \% \text { in acetone, and acetone were more effective for most compounds. } \\
\text { Chloroform and hexane extracted only one compound, possibly hyperforin. Best extraction time } 4-8 \mathrm{~h} \text {. } \\
\text { Phase II: experimental design and RSM showed optimum yield for all components } 44-59 \% \text { ethanol in } \\
\text { acetone, } 5.3-5.9 \mathrm{~h} \text {, and } 55^{\circ} \mathrm{C} \text {, except hypericin that showed maximum yield at } 23 \text { and } 40{ }^{\circ} \mathrm{C} \text {. }\end{array}$ & [172] \\
\hline $\begin{array}{l}\mathrm{CSE}\left(1 \mathrm{~g} / 30 \mathrm{~mL}, 4^{\circ} \mathrm{C}, 60 \mathrm{~min} \text {, under stirring and dark) }\right. \\
\text { Ethanol, acetonitrile, ethyl acetate, chloroform, } \\
\text { methyl-tert-butylether, petroleum ether, hexane }\end{array}$ & $\begin{array}{c}\text { HPLC } \\
\text { (hyperforin) }\end{array}$ & $\begin{array}{l}\text { All solvents presented close yields }(3.2-2.8 \mathrm{mg} / \mathrm{g} \text { dry plant), except ethanol that presented the lowest } \\
(1.9 \mathrm{mg} / \mathrm{g} \text { dry plant). Hexane and petroleum ether presented the highest purity (hyperforin content) in } \\
\text { the extracts. }\end{array}$ & [164] \\
\hline $\operatorname{SFE}\left(311,380\right.$, and $449 \mathrm{~atm}, 40,50$, and $\left.60^{\circ} \mathrm{C}\right)$ & $\begin{array}{c}\text { HPLC } \\
\text { (hyperforin) }\end{array}$ & $\begin{array}{l}\text { The optimum conditions were } 380 \mathrm{~atm}, 50^{\circ} \mathrm{C} \text {, static extraction } 10 \mathrm{~min} \text { followed by dynamic extraction } \\
90 \mathrm{~min} \text { at } \mathrm{CO}_{2} \text { flow rate } 1 \mathrm{~mL} / \mathrm{min} \text {. Extraction was not quantitative (about } 60 \% \text { of hyperforins } \\
\text { were extracted). } \\
\text { Addition of methanol did not increase yield, while decreased purity of the extract. }\end{array}$ & [163] \\
\hline SFE & $\begin{array}{c}\text { HPLC } \\
\text { (hyperforin) }\end{array}$ & $\begin{array}{c}\text { High extraction efficiency when } \mathrm{CO}_{2} \text { density }>0.60 \mathrm{~g} / \mathrm{mL} \text {. Mild conditions }\left(30^{\circ} \mathrm{C}, 80 \mathrm{~atm} \text {, }\right. \\
\text { density- } 0.64 \mathrm{~g} / \mathrm{mL}) \text { gave the best yield }(12 \mathrm{mg} / \mathrm{g} \text { dry plant) that was comparable to UAE or CSE at } \\
\text { boiling temperature }\end{array}$ & [171] \\
\hline $\begin{array}{c}\text { SFE }\left(100,150,200 \mathrm{~atm}, 40,50^{\circ} \mathrm{C} \text {, various } \mathrm{CO}_{2} \text { densities) }\right. \\
\text { UAE (methanol) }\end{array}$ & $\begin{array}{c}\text { HPLC } \\
\text { (hyperforins) }\end{array}$ & $\begin{array}{l}\text { The lower the } \mathrm{CO}_{2} \text { density (low pressure, high temperature) the lower the hyperforins yield and purity of } \\
\text { the extracts. } 200 \text { atm and } 313 \mathrm{~K} \text { gave the best results. Hypericins were not extracted. } \\
\text { Pretreatment with SFE }(100 \mathrm{~atm}, 313 \mathrm{~K}) \text { increased the yield of UAE extraction. }\end{array}$ & [170] \\
\hline $\begin{array}{c}\text { SFE (250 and } 300 \mathrm{~atm}, 40^{\circ} \mathrm{C} \text { or } 300 \mathrm{~atm} 50^{\circ} \mathrm{C} \text {, with or without } \\
10 \% \text { ethanol as co-solvent) } \\
\text { Subcritical } \mathrm{CO}_{2}\left(70 \mathrm{~atm}, 22^{\circ} \mathrm{C}\right)\end{array}$ & $\begin{array}{l}\text { HPLC } \\
\text { (hypericin hyperforin, } \\
\text { flavonoids) }\end{array}$ & $\begin{array}{l}\text { Hyperforin was easily extracted, while hypericin and flavonoids were not extracted even with ethanol. } \\
\text { The yield increased sharply under } \mathrm{SFE} \text { and slower with liquid } \mathrm{CO}_{2} \text {. Liquid } \mathrm{CO}_{2} \text { gave the highest } \\
\text { hyperforin yield and purity of the extract. Ethanol increased hyperforin yield but decreased purity of } \\
\text { the extract. }\end{array}$ & [169] \\
\hline $\begin{array}{c}\text { Soxhlet }(20 \mathrm{~g} / 200 \mathrm{~mL}) \\
\text { Ethanol, 2-propanol, ethyl acetate, hexane } \\
\mathrm{SFE}\left(40^{\circ} \mathrm{C}, 450 \text { atm, flow rate } 7 \mathrm{~kg} \mathrm{CO} /(\mathrm{h} \mathrm{kg} \text { herb })\right.\end{array}$ & $\begin{array}{l}\text { UV-vis (hypericin) } \\
\text { HPLC (hypericin hyperforin) }\end{array}$ & 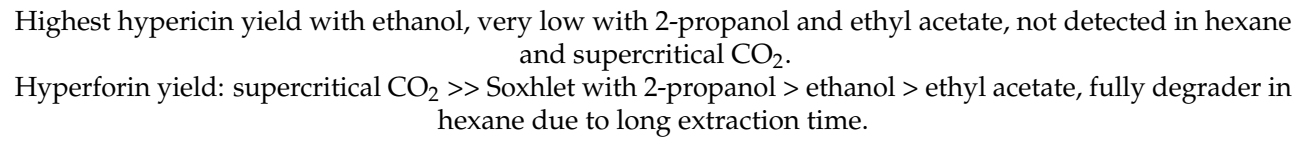 & [166] \\
\hline $\begin{array}{c}\text { Soxhlet }(5 \mathrm{~g} / 100 \mathrm{~mL}) \\
\text { methanol } 6 \mathrm{~h} \\
\text { successive with diethyl ether } 4 \mathrm{~h} \text {, and ethanol } 6 \mathrm{~h} \\
\mathrm{UAE} \text { (bath, } 1 \mathrm{~g}, 75 \mathrm{~mL}, 0.5 \mathrm{~h}, 2 \text { repeated extractions) } \\
\text { methanol } \\
\text { successive with petroleum ether, chloroform, ethyl acetate, } \\
\text { methanol } \\
\text { Digestion (1 } \mathrm{g} \text { with } 100 \mathrm{~mL} \text { hot methanol) } \\
\text { Maceration } \\
\text { a) } 1 \mathrm{~g} / 100 \mathrm{~mL} \text { methanol, under stirring, } 2 \mathrm{~h} \text { ) } \\
\text { b) } 1 \mathrm{~g} / 150 \mathrm{~mL} \text { acetone } 90 \% \text { in water, under stirring, } 0.5 \mathrm{~h} \text {, } \\
2 \text { repeated extractions) }\end{array}$ & $\begin{array}{l}\text { UV-vis (hypericin) } \\
\text { HPLC }\end{array}$ & $\begin{array}{c}\text { Only Soxhlet } b \text {, and maceration } b \text { gave extracts free from chlorophyll pigments. } \\
\text { Soxhlet } b \text { gave mainly hyperforin in diethyl ether and hypericins in ethanol. } \\
\text { Hyperforin was favored by lower temperature (UAE a, compared to Soxhlet a) and non-polar solvents } \\
\text { (petroleum ether in UAE b). } \\
\text { Flavonoids were favored by higher temperature (Soxhlet a and digestion, compared to UAE a and } \\
\text { maceration a). } \\
\text { The best extraction procedure to obtain a representative extract with all metabolites is UAE with methanol } \\
\text { or ethanol. }\end{array}$ & [157] \\
\hline
\end{tabular}


Table 6. Cont.

Extraction Method and Parameters

Soxhlet $(5 \mathrm{~g} / 150 \mathrm{~mL}$ methanol $24 \mathrm{~h}$ )

UAE (5 g/100 mL methanol, 5-60 min) Direct $(20 \mathrm{kHz}, 40$ or $60 \mathrm{~W})$ Indirect $(35 \mathrm{kHz})$

Maceration $(5 \mathrm{~g} / 100 \mathrm{~mL}$ methanol $24 \mathrm{~h})$ ASE (methanol, $\left.40^{\circ} \mathrm{C}, 100 \mathrm{~atm}\right)$

Soxhlet $(1 \mathrm{~g} / 200 \mathrm{~mL}$ methanol, 1-48 h)

UAE (bath, $1 \mathrm{~g} / 22 \mathrm{~mL}$ methanol, $60^{\circ} \mathrm{C}, 30-120 \mathrm{~min}$ )

ASE $\left(22-200^{\circ} \mathrm{C}, 152 \mathrm{~atm}, 5 \mathrm{~min}\right.$ heating, 5 min static time 3-cycle extraction

Methanol, tetrahydrofuran, acetone, methylene chloride, hexane
HPLC

(hyperforin was

not quantitated)
HPLC
Direct UAE showed the best yields for all compounds that increased with power $(60 \mathrm{~W}) .20$ min were
efficient for all compounds, except hyperforin that needed $5 \mathrm{~min}$.

Yields obtained by the rest methods followed the order Soxhlet $\geq$ ASE $\geq$ indirect UAE $>$ maceration.

Reference

Maximum yield in Soxhlet obtained at $8 \mathrm{~h}$

Increase of time in UAE increased components yields.

3-6 repeated ASE were necessary for the recovery of $99 \%$ of each component. All solvents were tested at $22{ }^{\circ} \mathrm{C}$, methanol or tetrahydrofuran were more effective for the extraction of phenolic acids and flavonoids, acetone was more effective for the extraction of the non-polar hypericins, while methylene chloride and hexane were ineffective. The effect of temperature was studied with ethanol. Yield increased with

merature up to $150^{\circ} \mathrm{C}$ and decreased afterwards, except quercetin that was degraded even at $150{ }^{\circ} \mathrm{C}$

For more polar compounds yield followed the order Soxhlet $(24 \mathrm{~h})>\operatorname{UAE}\left(60^{\circ} \mathrm{C}, 2 \mathrm{~h}\right)>\operatorname{ASE}\left(60^{\circ} \mathrm{C}, 0.5 \mathrm{~h}\right)$

Heating under reflux

(solvent boiling point, $90 \mathrm{~min}$ )

$\mathrm{UAE}\left(25^{\circ} \mathrm{C}, 30 \mathrm{~min}\right)$

$\operatorname{MAE}\left(75^{\circ} \mathrm{C}, 30 \mathrm{~min}\right)$

HPLC

Yield of all compounds followed the order ASE $>$ MAE $>$ heating under reflux $>$ UAE.

Heating under reflux at solid/liquid 1/100 presented yields comparable to ASE.

All methods $\mathrm{ASE}\left(120^{\circ} \mathrm{C}, 100-150 \mathrm{~atm}, 20 \mathrm{~min}\right)$

HPLC

(flavonoids and

phenolic acids)

$\mathrm{TPC} \mathrm{ABTS}^{+}$

HPLC

(phenolic compounds)

TPC, FRAP

BBD and analysis of results indicated all parameters significant. Optimization was based on quercetin yield that increased with methanol concentration and temperature, while it was not affected by $\mathrm{HCl}$ concentration at higher temperature. Cyanidin, kaempferol, and protocatechuic acid were also found in the extract.

CSE $(1 \mathrm{~g} / 50 \mathrm{~mL}$ under stirring) Water Glycerol in water $10 \%$

Aqueous glycerol (10\%) increased the extraction rate, compared to water, the phenolic compound yield (90 mg GAE/g dry herb, versus $78 \mathrm{mg} \mathrm{GAE} / \mathrm{g}$ dry herb for water), and the ferric reducing power (by $9 \%$ ).

Phenolic acids, quercetin glycosides, and catechin were the major extracted components, while hypericin was detected. CCD and RSM revealed $70^{\circ} \mathrm{C}$ and $69 \mathrm{~min}$ as optimum conditions.

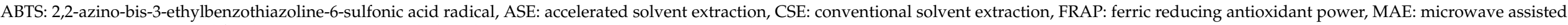
extraction, SFE: supercritical fluid extraction, TPC: total phenolic content, UAE: ultrasound assisted extraction. 
Fractionation of St. John's wort methanol extract and examination of the antioxidant activity of each fraction by FRAP, DPPH, superoxide, and NO radicals scavenging assays, indicated that the antioxidant activity was mostly attributed to flavonoid glycosides and phenolic acids (chlorogenic acid), while biflavonoids (lacking the catechol moiety), naphtodianthrones, and phloroglucinols showed very low activity [178]. Kalogeropoulos et al. [179] reported quercetin glycosides (hyperoside, quercitrin, and isoquercitrin) and catechin as the main flavonoid constituents of the methanol extract and associated them with the observed DPPH radical scavenging activity. The ethanol in water $(80 \%)$ extract of the plant presented activity against several radicals and also a high capacity to inhibit iron-mediated lipid peroxidation [180]. Correlating this capacity with the flavonoid profile of the plant and the antiradical activities of the identified components, the authors suggested that it should be attributed to the presence of components that possess antiradical properties together with iron-binding ability (mainly quercetin and kaempferol, but also biapigenin and quercetin glycosides). Additionally, $10 \%$ aqueous glycerol solutions and water infusions were found rich in chlorogenic acid and quercetin glycosides-but did not contain either hypericin or hyperforin—and presented appreciable FRAP, DPPH radical scavenging, and acetylcholisterenase inhibition activity [177,181].

\section{Saffron}

Crocus sativus L. (saffron) is a perennial herb belonging to Iridaceae family, originated and evolved in Attica (Greece) from the wild Crocus cartwrightianus, and probably domesticated there [182,183]. Since the Bronze Age saffron was grown in the eastern Mediterranean territories and the Middle East, while currently the cultivation of the plant has spread to more territories such as the USA, China, and Australia. However, the main production areas include a geographic zone between the Mediterranean, the Middle East countries, and India. Iran has been traditionally the main producer, accounting for more than $90 \%$ of the world production, followed by far by India, Greece, and Spain. The valuable part of the plant are the stigmas of flowers, with the requirement of harvesting $150,000-200,000$ flowers by hand, to get $1 \mathrm{~kg}$ of saffron stigmas [183]. This extremely low yield renders the saffron stigmas as the most expensive spice of the world.

The composition of stigmas, concerning the secondary metabolites, includes a major group of glycosylated apocarotenoids, named crocins, which are responsible for the dark red color of stigmas. The respective carotenoid aglycone of crocins is the $\mathrm{C}_{20}$ dicarboxylic acid crocetin ( $8,8^{\prime}$-diapocarotene- $8,8^{\prime}$-dioic acid), and all of them are water soluble components [184]. The $\mathrm{C}_{20}$ apocarotenoids of saffron could be distinguished to the all-trans members, including crocins and crocetin, and the 13-cis members, which are exclusively crocins (Figure $1 \mathrm{~b}$ ). However, the typical composition of the water-soluble apocarotenoids of saffron include two major all-trans compounds, namely trans-crocetin di-( $\beta$-D-gentiobiosyl) ester and trans-crocetin ( $\beta$-D-gentiobiosyl)-( $\beta$-D-glucosyl) ester, followed by the minor cis-crocetin ( $\beta$-D-gentiobiosyl)-( $\beta$-D-glucosyl) ester, while all of the other, approximately 13 components occurring in water extracts of saffron, appear as even minor components or traces, including crocetin [184,185].

The abbreviations of crocins followed by most researchers can be detected as early as 1995 at the manuscript of Tarantilis et al. [186]. At the respective paper, authors abbreviate each crocin as crocin- $\mathrm{n}$, where $\mathrm{n}$ indicates the total number of glucose moieties. Therefore, according to Tarantilis et al. [186] the major crocin (trans-crocetin di-( $\beta$-D-gentiobiosyl) ester) is abbreviated as crocin-4, while trans-crocetin ( $\beta$-D-gentiobiosyl)-( $\beta$-D-glucosyl) ester as crocin-3. Crocins- 2 are discriminated as crocin-2 [trans-crocetin $\beta$-D-gentiobiosyl ester] and crocin-2' [trans-crocetin di-( $\beta$-D-glucosyl) ester]. Carmona et al. [187] extended the abbreviations so as to present more structural details, i.e., the first part describes the cis/trans form of the aglycone, followed by the total number of sugar moieties (glucose monomers), and finally, the type of sugar in each part of the crocin structure (G refers to gentiobiose; $g$, to glucose; $n$, to neapolitanoside; $t$, to triglucoside). Therefore crocin- 4 is abbreviated as trans-4-GG, according to Carmona et al. [187], while crocin-3 as trans- 
3-Gg. Synthesizing the two systems, trans-crocetin di-( $\beta$-D-gentiobiosyl) ester should be abbreviated as trans-crocin-4-GG or trans-4-GG crocetin ester, however the versions of trans-crocin- 4 or trans-crocin 4 are mainly detected in the literature, assuming that the glycosylation pattern of the compound is generally taken for granted. Other types of abbreviations such as the one of Siracusa et al. [184] are used in a far lesser extent in the literature. Crocins are coded as crocin- $n$, where $n$ is, assumingly, an indication of the abundance of the respective compound. The most abundant trans-crocetin di- $(\beta-D-$ gentiobiosyl) ester is named as crocin- 1 , the second trans-crocetin ( $\beta$-D-gentiobiosyl)- $(\beta-D-$ glucosyl) ester as crocin-2 etc.

Other significant components of saffron stigmas are the $\mathrm{C}_{10}$ picrocrocin (a bitter taste glucoside) and safranal (Figure 1b), the main volatile component of saffron, responsible for its particular aroma, both of which derive from the carotenoid oxidation pathway [184].

Apart from the value of stigmas as spice, they appear to be a significant source of bioactive components against a broad range of pathological conditions and disorders as presented in numerous reports. In recent papers it has been evidenced that crocins can modulate the serum lipid profile in patients with metabolic disorders [188], prevent cancer, and present antitumor activities, according to experiments with cultured human malignant cell lines and animal models [189]. Kazemi et al. [190] have demonstrated that treatment of patients, with mild to moderate obsessive-compulsive disorder, with saffron crocin is equally effective to fluoxetine, while saffron intake has been associated with improvements in sleep quality in adults with self-reported sleep complaints [191].

The potential valorization of crocins, picrocrocin or safranal as novel natural pharmaceuticals or even nutraceuticals require efficient extraction protocols. Thus, various research teams focused on the development of extraction methods. It is noted that several researchers have been based on the recommended extraction protocols of the ISO, such as the ISO 3632-2:2010 [192], and tried to optimize them with the use of assisting techniques, i.e., UAE or MAE. In the above protocol the solid-to-liquid ratio equals $1 / 2000$ and ensures practically the total extraction of bioactives. The optimization of such procedure could be applicable only for analytical purposes, due to the high dilution of the extract. The potential valorization of an extract requires the minimum use of solvent with the highest yield of compounds.

Table 7 presents the research works that go beyond the analytical purposes and approach the production of saffron extracts promising for industrial application. The basic extraction protocol of saffron includes water as extraction solvent, since the major components, crocins and crocetin, are water-soluble. However, several pure organic solvents such as ethanol, methanol, acetone, etc., have been applied [193] with limited success.

Mixtures of various organic solvents with water have also been examined, with ethanolwater and methanol-water to surpass other systems [194-198]. The references dealing with ethanol-water or methanol-water mixtures could be distinguished in two categories; those that implement conventional extractions methods, i.e., agitation and maceration [194,195] and the ones that apply the modern assisting techniques of UAE and MAE [196-198]. CSEs applied ethanol-water 1:1 mixtures, with high solid-to-liquid ratios, namely 1/20 and 1/30 [195,196]. Montalvo-Hernandez et al. [194] succeeded a 77\% recovery of saffron crocins agitating at $200 \mathrm{rpm}$ for $1 \mathrm{~h}$ a mixture of saffron powder and ethanol-water (50\%) at ratio of $1 / 20$. The use of assisting techniques, significantly reduced the duration of extractions that ranged between 5 and 30 min [197-199]. Especially Kyriakoudi et al. [197] with 29 min extraction time, methanol 50\% in water, at solid/liquid ratio $1 / 180$, under UAE, reached a total yield of $627 \mathrm{mg}$ crocetin esters/g saffron, which is the highest value found in the literature. High hydrostatic pressure (HHP) can be considered a novel assisting technique of extraction; Shinwari et al. [199] applied HHP to a mixture of saffron powder with water (solid/liquid, 1/100), pressure $5800 \mathrm{~atm}$, temperature $50{ }^{\circ} \mathrm{C}$, time $5 \mathrm{~min}$, and recovered crocins (yield amounting to $25 \%$ of theoretical) and picrocrocin. 
Table 7. The extraction parameters of Crocus sativus stigmas, as recorder from the extensive review of literature.

\begin{tabular}{|c|c|c|c|c|}
\hline Solvent & Method & Measured Parameters & Main Results & Reference \\
\hline $\begin{array}{l}\text { Water (solid/liquid } \\
1 / 2000, w / v)\end{array}$ & $\begin{array}{l}\text { CSE with magnetic } \\
\text { stirring at } 1000 \mathrm{rpm} \text { for } 1 \mathrm{~h} \\
\text { under dark } \\
\text { (ISO 3632-2:2010) }\end{array}$ & $\begin{array}{c}\text { UV-vis } \\
\text { spectrophotometry }\end{array}$ & $\begin{array}{l}\text { picrocrocin, safranal and crocins are } \\
\text { expressed as direct reading of the } \\
\text { absorbances produced by the } 1: 10 \text { dilution } \\
\text { of the extract at } 257,330 \text { and } 440 \mathrm{~nm}\end{array}$ & [192] \\
\hline $\begin{array}{c}\text { Methanol, ethanol, } \\
\text { propanol, acetone, ethyl } \\
\text { acetate and petroleum } \\
\text { ether } \\
\text { (solid/liquid } 1 / 50, w / v)\end{array}$ & $\begin{array}{c}\text { Soxhlet } \\
\text { Cold percolation }\end{array}$ & $\begin{array}{l}\text { UV-vis } \\
\text { spectrophotometry, } \\
\text { HPLC-UV }\end{array}$ & $\begin{array}{l}\text { Soxhlet (overnight): acetone recovered } \\
\text { picrocrocin in the highest yield, while } \\
\text { methanol was more effective for the } \\
\text { extraction of safranal and crocins. } \\
\text { Cold percolation (overnight): the safranal } \\
\text { content of oleoresin remain more intact in } \\
\text { this method }\end{array}$ & [193] \\
\hline $\begin{array}{l}\text { Ethanol-water mixtures } \\
\quad(\text { solid } / \text { liquid } \\
1 / 10-1 / 40, w / v)\end{array}$ & $\begin{array}{l}\text { CSE (agitation at } 200 \mathrm{rpm} \\
\text { for up to } 60 \mathrm{~min} \text {, at } \\
25^{\circ} \mathrm{C} \text {, and } \\
\text { protected from light }\end{array}$ & HPLC-DAD, TPC & $\begin{array}{l}\text { Optimization for crocins: ethanol } 50 \% \\
(v / v) \text {, temperature } 25^{\circ} \mathrm{C} \text {, solid/solvent } \\
1 / 20 \text {; recovery } 77 \% \text { of theoretical }\end{array}$ & [194] \\
\hline
\end{tabular}

Distilled water (DW) ethanol/DW, methanol/DW, propylene glycol/DW, heptane/DW and hexane/DW (solid/liquid 1/30,w/v)

Maceration $\left(72 \mathrm{~h}, 25^{\circ} \mathrm{C}\right) \quad \begin{gathered}\mathrm{UV}-\mathrm{v} \text { is } \\ \text { spectrophotometry }\end{gathered}$

Ethanol-water was the most efficient solvent for the extraction of crocin and safranal, while methanol-water was the most efficient for picrocrocin

\begin{tabular}{|c|c|c|c|c|}
\hline $\begin{array}{l}\text { Ethanol in water } 50 \% \\
\text { (solid/liquid } 1 / 10 \\
1 / 20 \text { w/v) }\end{array}$ & $\begin{array}{c}\text { MAE: } 200 \mathrm{~W} \text { (under } \\
\text { magnetic stirring, } 50^{\circ} \mathrm{C} \text {, } \\
18 \mathrm{~min} \text { ) } \\
\text { UAE: (33 KHz, room } \\
\text { temperature, } 30 \mathrm{~min} \text { ) }\end{array}$ & ABTS, DPPH, FRAP, TPC & $\begin{array}{l}\text { The MAE method was more effective } \\
\text { compared to the UAE method, with six } \\
\text { fold higher yield. }\end{array}$ & [196] \\
\hline $\begin{array}{l}\text { Methanol in water } 50 \% \\
\quad(\text { solid /liquid } \\
1 / 180-1 / 1800, w / v)\end{array}$ & $\begin{array}{l}\text { UAE. Amplitude setting } \\
\text { range, } 10-100 \text { in } 1 \% \\
\text { increments; frequency, } \\
20 \mathrm{kHz} \\
\text { and output, } 70 \mathrm{~W} ; \\
100 \% \text { amplitude; } \\
\text { temperature: } 15 \pm 0.5^{\circ} \mathrm{C}\end{array}$ & $\begin{array}{l}\text { HPLC-DAD, Optical } \\
\text { Microscopy }\end{array}$ & $\begin{array}{l}\text { Optimal conditions for crocins recovery: } \\
\text { solid/liquid } 1 / 180 \mathrm{w} / \mathrm{v} \text {; sonication time: } \\
29 \mathrm{~min} \text {; yield } 627 \mathrm{mg} / \mathrm{g} \text { saffron }\end{array}$ & [197] \\
\hline $\begin{array}{l}\text { Ethanol in water } 50 \% \\
\text { (solid/liquid } 1 / 20, w / v)\end{array}$ & $\begin{array}{l}\text { UAE. frequency } 25 \mathrm{kHz} \text {; } \\
\text { power: } 100 \mathrm{~W} \text {; sonication } \\
\text { time } 1-10 \mathrm{~min} ; \\
\text { temperature } 25^{\circ} \mathrm{C}\end{array}$ & $\begin{array}{c}\text { UV-vis } \\
\text { spectrophotometry }\end{array}$ & $\begin{array}{l}\text { Optimal time to extract crocin, picrocrocin } \\
\text { and safranal was } 10 \text { min. The yield was } \\
\text { higher than with maceration for } 72 \mathrm{~h} \text {. }\end{array}$ & [198] \\
\hline $\begin{array}{c}\text { Water } \\
(\text { solid/liquid } 1 / 100, w / v)\end{array}$ & $\begin{array}{l}\text { Hydration of the ground } \\
\text { material for } 2 \mathrm{~h} \text { at } 4{ }^{\circ} \mathrm{C}, \\
\text { and then application of } \\
\text { high hydrostatic pressure }\end{array}$ & $\begin{array}{l}\text { UV-vis } \\
\text { spectrophotometry (ISO } \\
\text { method), HPLC-DAD }\end{array}$ & $\begin{array}{l}\text { Optimal conditions for maximum } \\
\text { extraction of safranal, picrocrocin and } \\
\text { crocin: } 5800 \mathrm{~atm} \text { and } 50^{\circ} \mathrm{C} \text {. Total yield of } \\
\text { crocins more than } 250 \mathrm{mg} / \mathrm{g}\end{array}$ & [199] \\
\hline $\mathrm{CO}_{2}$ & $\begin{array}{c}\text { SFE } \\
200 \mathrm{~atm}, 100^{\circ} \mathrm{C}\end{array}$ & $\begin{array}{c}\text { Safranal } \\
\text { GC-FID, HPLC-DAD }\end{array}$ & $\begin{array}{l}0.476 \mathrm{~g} / \mathrm{mL} \text { fluid density (200 atm and } \\
100{ }^{\circ} \mathrm{C} \text { ); total extraction of safranal } \\
\text { within } 30 \mathrm{~min}\end{array}$ & [200] \\
\hline $\begin{array}{l}\text { Supercritical } \mathrm{CO}_{2} \\
\text { (solid/S. Fluid } \\
1 / 3755, w / v)\end{array}$ & $\begin{array}{c}\text { SFE } \\
\text { Extraction between } 30 \text { and } \\
190 \text { min }\end{array}$ & GC-MS & $\begin{array}{l}\text { Optimal conditions: temperature } 44.9^{\circ} \mathrm{C} \text {; } \\
\text { pressure } 349 \mathrm{~atm} \text {; extraction time } \\
150.2 \mathrm{~min} ; \mathrm{CO}_{2} \text { flow rate } 10.1 \mathrm{~L} \mathrm{~h}^{-1} \text {; yield } \\
10.94 \mathrm{mg} / \mathrm{g} \text { from the non-polar fraction }\end{array}$ & [201] \\
\hline $\begin{array}{l}\mathrm{CO}_{2} \text { and } \mathrm{CO}_{2} \text {-methanol } \\
(\text { solid } / \mathrm{S} \text {. Fluid } 1 / 73, w / v)\end{array}$ & SFE & HPLC-UV/vis detector & $\begin{array}{l}\text { Optimal recovery of crocin }(32.67 \% \mathrm{w} / \mathrm{w}) \text { : } \\
44^{\circ} \mathrm{C}, 193 \mathrm{~atm}, 1.0 \mathrm{~cm}^{3} / \mathrm{min}, 110 \mathrm{~min} \\
\text { Safranal }(\text { recovery } 91.8 \% \mathrm{w} / \mathrm{w}): 92^{\circ} \mathrm{C} \\
213 \mathrm{~atm}, 0.9 \mathrm{~cm}^{3} \mathrm{~min}, 122 \mathrm{~min}\end{array}$ & [202] \\
\hline $\begin{array}{c}\mathrm{CO}_{2} \\
\text { (solid/S. Fluid 1/1440; } \\
\text { solid/liquid methanol or } \\
\text { water as modifier, } \\
1 / 96 / \mathrm{V} \text { ) }\end{array}$ & $\begin{array}{l}\mathrm{SFE} \text {; duration } 240 \mathrm{~min} ; \\
\mathrm{CO}_{2} \text { pump flow rate } \\
3 \mathrm{~mL} / \mathrm{min} \text {; modifier flow } \\
\text { rate of } 0.2 \mathrm{~mL} / \mathrm{min} .\end{array}$ & HPLC-UV/vis detector & $\begin{array}{l}\text { Crocin was optimally extracted at } 80^{\circ} \mathrm{C} \\
\text { and } 300 \text { atm using water as a modifier. } \\
\text { Optimal conditions for safranal: } 80^{\circ} \mathrm{C} \\
\text { and } 400 \mathrm{~atm} \text { using methanol as a modifier }\end{array}$ & [203] \\
\hline
\end{tabular}

ABTS: 2,2-azino-bis-3-ethylbenzothiazoline-6-sulfonic acid radical, CSE: conventional solvent extraction, DPPH: 1,1-diphenyl-2picrylhydrazyl radical, FRAP: ferric reducing antioxidant power, MAE: microwave assisted extraction, SFE: supercritical fluid extraction, TPC: total phenolic content, UAE: ultrasound assisted extraction. 
SFE has also been applied to recover saffron components. Pure $\mathrm{CO}_{2}$ has been used for the extraction of safranal and non-volatile lipids [200-202], while concerning crocins, picrocrocin and crocetin the use of a modifier was considered necessary [202,203]. Nerome et al. [203] succeeded the recovery of crocin and picrocrocin, at respective yields of $68.8 \%$ and $88.4 \%$, with the use of water as a modifier.

While stigmas are considered as the valuable part of the herb, the petals amount to $99.7 \%$ of harvested material and remain unexploited. According to Caser et al. [204] $1 \mathrm{~kg}$ of stigmas correspond to $350 \mathrm{~kg}$ of petals, which are regarded as agricultural waste. However, in recent years, and in the frame of new ecofriendly trends such as the circular economy and the sustainable growth, the valorization of petals has gained the interest of the scientific community. According to early studies, saffron petals contain flavonoids with major components the glycosylated derivatives of quercetin and kaempferol, including their methoxylated and acetylated derivatives [204,205]. In the study of Termentzi and Kokkalou [205], the CSE of saffron petals with methanol yielded $12 \% w / w$ in extractable components. Authors determined the flavonoid concentration in the methanolic extract $13 \%$, thus the flavonoid content reaches $16 \mathrm{mg} / \mathrm{g}$ on petals basis. Further analyses revealed a total alkaloid yield in the magnitude of $0.9 \mathrm{mg} / \mathrm{g}$, and the monoterpene crocusatin at $57.5 \mathrm{ppm}$. Furthermore, five anthocyanins have been reported (delphinidin, petunidin, and malvidin glycosides) and quantified at $4.8 \mathrm{mg} / \mathrm{g}$, and lutein diesters (215 ppm, on petals basis) [206].

The studies on the application of extraction methods at larger than the analytical scale have started recently, since 2016, and include conventional extraction methods, such as maceration, and novel techniques. In most cases conventional methods have been used for comparison reasons with modern assisting techniques, i.e., UAE, MAE, Ohmic heating assisted extraction (OHAE), SFE, and SWE. Water, ethanol-water, and $\mathrm{CO}_{2}$-ethanol mixtures appeared until recently as the only solvents used for the recovery of compounds. In a research paper of 2021 [207], methanol was used for the first time, in mixtures with water, as potential solvent for petals extraction. The extraction methods from the literature together with their respective optimization parameters are summarized in Table 8 .

The first study of petals extraction with potential application in large scale is the one of Ahmadian-Kouchaksaraie et al. [208], who optimized the SWE of petals powder. They concluded that the optimal conditions for SWE were solid/liquid 1/36, temperature of $159^{\circ} \mathrm{C}$, and time $54 \mathrm{~min}$. At the above conditions they achieved a total phenol yield of $16.2 \mathrm{mg} / \mathrm{g}$ dry plant powder, and flavonols yield of $2.39 \mathrm{mg} / \mathrm{g}$. Water was also used by Hashemi et al. (2020) [213]. They performed CSE (agitation) of petals with hot water $\left(66^{\circ} \mathrm{C}\right)$ at a solid/liquid ratio of 1/36, for $104 \mathrm{~min}$ and yielded TPC $7.21 \mathrm{mg} / \mathrm{g}$, TFC $1.01 \mathrm{mg} / \mathrm{g}$, and TAC $1.89 \mathrm{mg} / \mathrm{g}$. Additionally, Stelluti et al. [207] macerated petals powder with water under stirring (1000 rpm) in the dark for $30 \mathrm{~min}$, at $21^{\circ} \mathrm{C}$, yielding TPC $11.4 \mathrm{mg} / \mathrm{g}$ and TAC $3.45 \mathrm{mg} / \mathrm{g}$.

Khazaei et al. [209] optimized the extraction of anthocyanins, macerating saffron petals with hydroalcoholic mixtures; at the optimal conditions (solid/liquid 1/20, ethanol concentration in water $25 \%$, extraction temperature $25.8{ }^{\circ} \mathrm{C}$, duration of extraction $24 \mathrm{~h}$ ) they obtained $32 \mathrm{mg}$ total monomeric anthocyanins/g dry material. The maximum yield of anthocyanins detected in the literature, reached $101 \mathrm{mg} / \mathrm{g}$ dry tepals powder by Jafari et al. [212]. The researchers obtained such a high yield by extracting petals with a mixture of acidified ethanol-water at solid/liquid ratio 1/20 using MAE. In all other cases the total anthocyanins yield, ranged between 1 and $4 \mathrm{mg} / \mathrm{g}$.

Ahmadian-Kouchaksaraie and Niazmand [210] optimized SFE of petals. They used a volume of distilled preheated water before filling the vessel. For extraction by $\mathrm{SC}_{2} \mathrm{CO}_{2}$, the ratio of solid-to-liquid ratio was $1 / 30$ with $5 \%(v / v)$ of ethanol, while the optimal conditions were determined $62{ }^{\circ} \mathrm{C}, 47 \mathrm{~min}$ extraction time, and pressure of $164 \mathrm{~atm}$. The yield of TPC reached $14.2 \mathrm{mg} / \mathrm{g}$, total flavonoid content (TFC) $1.8 \mathrm{mg} / \mathrm{g}$, and total anthocyanin content (TAC) $1 \mathrm{mg} / \mathrm{g}$. 
Table 8. The extraction parameters of Crocus sativus petals, as obtained from the review of literature.

\begin{tabular}{|c|c|c|c|c|}
\hline Solvent & Method & Measured Parameters & Main Results & Reference \\
\hline $\begin{array}{c}\text { Water } \\
(\text { solid } / \text { liquid } 1 / 36, w / v)\end{array}$ & ASE (SWE) & $\begin{array}{c}\text { UV-vis } \\
\text { spectrophotometry } \\
\text { TPC, TFC, DPPH, FRAP }\end{array}$ & $\begin{array}{l}\text { Optimum conditions: } 159^{\circ} \mathrm{C}, 54 \mathrm{~min} \\
\text { TPC yield } 16.2 \mathrm{mg} / \mathrm{g} \text {, and flavonols yield } \\
2.39 \mathrm{mg} / \mathrm{g} .\end{array}$ & [208] \\
\hline $\begin{array}{c}\text { Ethanol-water } \\
\text { (solid/liquid } 1 / 20, w / v)\end{array}$ & Maceration & $\begin{array}{l}\text { UV-vis } \\
\text { spectrophotometry TAC }\end{array}$ & $\begin{array}{l}\text { ethanol concentration in water } 25 \% \text {, } \\
\text { extraction temperature } 25.8^{\circ} \mathrm{C} \text {, duration of } \\
\text { extraction } 24 \text { h; total monomeric } \\
\text { anthocyanins yield } 32 \mathrm{mg} / \mathrm{g}\end{array}$ & [209] \\
\hline $\begin{array}{l}\mathrm{CO}_{2} \\
\text { (solid/liquid } 1 / 30, w / v ; 5 \% \\
\text { v/v ethanol) }\end{array}$ & SFE & $\begin{array}{l}\text { UV-vis } \\
\text { spectrophotometry } \\
\text { TPC, TFC, TAC, } \\
\text { DPPH, FRAP }\end{array}$ & $\begin{array}{c}62{ }^{\circ} \mathrm{C}, 47 \mathrm{~min} \text { extraction time and pressure } \\
164 \mathrm{~atm} \text {; TPC yield } 14.7 \mathrm{mg} / \mathrm{g} \text {, TFC } \\
1.8 \mathrm{mg} / \mathrm{g} \text {, TAC } 1 \mathrm{mg} / \mathrm{g}\end{array}$ & [210] \\
\hline $\begin{array}{c}\text { Ethanol-water 59:41 } \\
\text { (solid/liquid 1/20 (CSE), } \\
\text { 1/30 (UAE), } \\
1 / 50(\mathrm{MAE}), w / v)\end{array}$ & CSE, UAE, MAE & $\begin{array}{l}\text { UV-vis } \\
\text { spectrophotometry } \\
\text { TPC, TAC, DPPH }\end{array}$ & $\begin{array}{l}\text { Maceration: } 66^{\circ} \mathrm{C} \text { for } 15 \mathrm{~min} \\
\text { Yields: TPC } 45 \mathrm{mg} / \mathrm{g} \text {, TAC } 4.6 \mathrm{mg} / \mathrm{g} \\
\text { UAE: } 66^{\circ} \mathrm{C} \text { for } 2 \mathrm{~min} \\
\text { Yields: TPC } 47 \mathrm{mg} / \mathrm{g} \text {, TAC } 5.3 \mathrm{mg} / \mathrm{g} \\
\text { MAE: } 66^{\circ} \mathrm{C} \text { for } 2 \mathrm{~min} \\
\text { Yields: TPC } 43 \mathrm{mg} / \mathrm{g} \text {, TAC } 5.2 \mathrm{mg} / \mathrm{g}\end{array}$ & [211] \\
\hline $\begin{array}{l}\text { Ethanol-water 50:50, } 25: 75 \\
\text { acidified with HCL } 0.1 \mathrm{~N} \\
\text { up to } \mathrm{pH}=2 \\
\text { (solid/liquid } 1 / 77.5, w / v \text { ) }\end{array}$ & MAE & $\begin{array}{l}\text { UV-vis } \\
\text { spectrophotometry } \\
\text { TAC }\end{array}$ & $\begin{array}{l}\text { MAE: temperature } 48^{\circ} \mathrm{C} \text {, power } 360 \mathrm{~W} \text {, } \\
\text { extraction time } 9.3 \mathrm{~min} ; \mathrm{TAC} \text { yield } 101 \mathrm{mg} / \mathrm{g}\end{array}$ & [212] \\
\hline $\begin{array}{l}\text { Water }(0.3 \% w / v \mathrm{NaCl}) \\
\quad(\text { solid /liquid } 1 / 20)\end{array}$ & $\begin{array}{l}\text { CHWE, OHAE, UAE, } \\
\text { MAE }\end{array}$ & $\begin{array}{c}\text { UV-vis } \\
\text { spectrophotometry } \\
\text { TPC, TFC, TAC, DPPH } \\
\text { LC-MS }\end{array}$ & $\begin{array}{c}\text { CHWE: agitation, } 66^{\circ} \mathrm{C} \text { for } 104 \mathrm{~min} \text {; (dry } \\
\text { herb) TPC } 7.21 \mathrm{mg} / \mathrm{g} \text { TFC } 1.01 \mathrm{mg} / \mathrm{g} \text {, TAC } \\
1.89 \mathrm{mg} / \mathrm{g} \\
\text { OHAE: } 45 \mathrm{~min}-225 \mathrm{~V} \text {; (dry herb) TPC } \\
9.28 \mathrm{mg} / \mathrm{g}, \text { TFC } 1.48 \mathrm{mg} / \mathrm{g} \text {, TAC } 2.38 \mathrm{mg} / \mathrm{g} \\
\mathrm{MAE}: 4.25 \mathrm{~min}-500 \mathrm{~W} \text {; (dry herb) TPC } \\
8.69 \mathrm{mg} / \mathrm{g} \text {, TFC } 1.15 \mathrm{mg} / \mathrm{g} \text {, TAC } 2.06 \mathrm{mg} / \mathrm{g} \\
\text { UAE: } 40.61 \mathrm{~min}-135.3 \mathrm{~W} \text {; (dry herb) TPC } \\
8.63 \mathrm{mg} / \mathrm{g} \text {, TFC } 1.30 \mathrm{mg} / \mathrm{g} \text {, TAC } 2.05 \mathrm{mg} / \mathrm{g}\end{array}$ & [213] \\
\hline $\begin{array}{l}\text { Water, Methanol-water } \\
\text { (solid/liquid } 1 / 50 \text { ) }\end{array}$ & maceration, UAE & $\begin{array}{l}\text { UV-vis } \\
\text { spectrophotometry } \\
\text { TPC, TAC, FRAP, } \\
\text { ABTS, DPPH } \\
\text { HPLC-DAD }\end{array}$ & $\begin{array}{l}\text { Maceration with water under stirring } \\
\text { (1000 rpm) under dark for } 30 \mathrm{~min} \text {, at } 21^{\circ} \mathrm{C} \text { : } \\
\text { TPC } 11.4 \mathrm{mg} / \mathrm{g} \text {, TAC } 3.45 \mathrm{mg} / \mathrm{g} \\
\text { UAE with water at } 23 \mathrm{kHz} \text { for } 15 \mathrm{~min} \text { : TPC } \\
11.5 \mathrm{mg} / \mathrm{g} \text {, TAC } 4.13 \mathrm{mg} / \mathrm{g}\end{array}$ & [207] \\
\hline
\end{tabular}

ABTS: 2,2-azino-bis-3-ethylbenzothiazoline-6-sulfonic acid radical, ASE: accelerated solvent extraction, CHWE: conventional hot water extraction, CSE: conventional solvent extraction, DPPH: 1,1-diphenyl-2-picrylhydrazyl radical, FRAP: ferric reducing antioxidant power, MAE: microwave assisted extraction, OHAE: Ohmic heating assisted extraction, SFE: supercritical fluid extraction, SWE: subcritical water extraction, TAC: Total Anthocyanin content, TPC: total phenolic content, TFC: Total flavonoids content, UAE: ultrasound assisted extraction.

As far as the assisting techniques are concerned, we can notice that solid/liquid ratios ranged between $1 / 50$ and $1 / 20$, and durations $2-45 \min [207,211,213]$. Compared with the respective conventional extractions the TPC yields varied between 96 and $129 \%$ of the theoretical values. The MAE method proposed by Hashemi et al. [213] could be distinguished, since they used the highest solid to liquid ratio, namely $1 / 20$, water (with $0.3 \% \mathrm{NaCl}$ content) as solvent, and increased the yield of TPC by $21 \%$, in comparison with the respective conventional method, applying a rapid extraction protocol, that lasted only $4.25 \mathrm{~min}$.

In general, crocins are recognized as the most valuable bioactive components of saffron. Assimopoulou et al. [214] studied their antiradical activities against DPPH and especially the activity of crocin-4. Using a DPPH protocol with $2 \mathrm{~h}$ incubation, they determined $\mathrm{EC}_{50}=0.516 \mathrm{mg}_{\text {crocin }} / \mathrm{mg}_{\mathrm{DPPH}}$, a value that can be converted to $0.21 \mathrm{~mol}_{\mathrm{crocin}} / \mathrm{mol}_{\mathrm{DPPH}}$, according to the respective $\mathrm{M}_{\mathrm{r}}$ values of crocin and DPPH. Therefore, the number of radicals scavenged by each crocin molecule $(n)$ corresponds to 2.4 (1:2.4) based on the formula $n=1 /\left(2 \times \mathrm{EC}_{50}\right)$, where $\mathrm{EC}_{50}$ is expressed as $\mathrm{mol}_{\text {crocin }} / \mathrm{mol}_{\mathrm{DPPH}}$. A stoichiometric factor of such magnitude is close to the respective values of potent antiradical structures, such as the B-catecholic flavonoids [215,216]. Dar et al. [217] determined even higher activity, comparing crocin with kaempferol $(n=2,[216])$ and ascorbic acid, that in terms of $\mathrm{IC}_{50}$ (expressed as $\mu \mathrm{mol} / \mathrm{mL}$ ) the two latter present similar activity [217]. 
Apart from extracting crocins, further efforts have been held in order to formulate stable extracts, in which the bioactive components are protected from environmental conditions, and thus could be easily handled as new ingredients in foods, cosmetics, and nutraceuticals. The encapsulation of crocins in protective matrices such as maltodextrin and alginates with further spray and freeze drying have already been successfully applied [218-220], and increase the possibility of the commercial use of saffron extracts. Ensuring the protection of crocins with appropriate carriers, then the respective commercial products could be standardized in terms of crocin content, probably according to the ISO protocols.

\section{Conclusions}

R. officinalis, O. vulgare, M. officinalis, and S. thymbra are among the most potent members of the Lamiaceae family for the extraction of antioxidant compounds. All of them contain appreciable amounts of phenolic acids (mainly rosmarinic acid) and flavonoids, which have been associated with the antioxidant activity and several health-beneficial effects of their extracts. Extracts rich in antioxidant compounds can be obtained by ethanol in water solutions (around $60 \%$ ) and the extraction time may be shortened by a moderate increase of temperature (up to $60^{\circ} \mathrm{C}$ ) or by UAE application. Water can be also used, although the recovery (especially of the flavonoid aglycones) and the purity of the extracts is lower. ASE is a promising technique that enhances mass transfer phenomena and reduces extraction time, provided the necessary equipment is available. Pure ethanol applied in ASE or UAE presented high yield and selectivity for phenolic compounds, thus providing extracts with high antioxidant activity.

Both UAE and ASE have emerged as fast extraction techniques that need lower amounts of solvents, and therefore are more economical and have a lower environmental impact. Moreover, the use of ethanol and mostly water renders them green extraction techniques. In particular in ASE applications, the use of high temperature decreases the dielectric constant of water providing properties similar to organic solvents. Thus, water can be a real alternative to organic solvents in applications that do not involve the extraction of compounds with high temperature sensitivity. MAE has similar advantages to UAE and ASE but the high rate of microwave energy absorbance by water may result to overheating and destruction of sensitive compounds, thereby the use of mixtures with organic solvents seems necessary to obtain good yields.

In addition to phenolic acids and flavonoids, $R$. officinallis contains phenolic diterpenes (carnosic acid and carnosol) that exhibit high antioxidant activity, especially in lipid substances. Acetone or hexane, with the aid of UAE, can be used to extract selectively the phenolic diterpenes and obtain high purity of the extracts. Nevertheless, acetone in water, or ethanol in water $(60-80 \%)$ lead to high recovery of all antioxidant components (carnosic acid, carnosol, rosmarinic acid, and flavonoids).

H. perforatum contains several flavonoids and phenolic acids but, also, phloroglucinols and naphtodianthrones that have several medical applications. Pure extracts of phloroglucinols are difficult to achieve, and can be obtained by hexane extraction or SFE with neat $\mathrm{CO}_{2}$. On the other hand, naphtodianthrones cannot be separated from flavonoids and extraction procedures with ethanol in water solutions provide the best results for a simultaneous recovery of all compounds, similarly to the Lamiaceae family plants.

Crocus sativus is a rich source of bioactives, both from stigmas and petals. The most valuable compounds of stigmas include crocetin glycosides, which can be efficiently extracted either with water, water/ethanol, or water/methanol mixtures. The assisting techniques significantly reduce the duration of extraction and increase both solid/liquid ratio and yield, especially for the latter reaching $627 \mathrm{mg} / \mathrm{g}$ saffron. The petals of saffron that are considered as a byproduct of stigmas production, contain methoxylated and acetylated flavonol aglycones and glycosides, and anthocyanins. The content of the above compounds, ranges in a much lower level than the respective of crocins in stigmas however in recent years, many researchers have attempted the valorization of petals. Novel 
assisting extraction techniques have been employed, achieving very short durations of extractions, e.g., 2-10 $\mathrm{min}$, with the use of water in high solid/liquid ratios, such as 1/20, or ethanol-water mixtures, and in combination with the abundance of the raw material could lead to industrial applications.

Future research should focus on the scale up of extraction techniques to allow industrial application. With regards to CSE, semicontinuous or continuous extraction procedures must be examined as they allow solvent recycling and more feasible production costs. For the novel techniques (UAE, ASE, and MAE), the degradation kinetics of the sensitive compounds should be clearly defined, so as to optimize the extraction parameters, i.e., extraction time and temperature. Additionally, extensive research is carried nowadays about the health effects of several phenolic compounds, like rosmarinic acid. The results of this research may guide the future efforts towards the selective extraction of the specific health-promoting compounds and standardization of the relevant extracts.

Supplementary Materials: The following are available online. Table S1: Identified phenolic compounds in Lamiaceae herbs extracts reported in literature references.

Author Contributions: Conceptualization, V.O.; methodology, D.T. and V.O.; investigation, E.C., A.O., D.T. and V.O.; resources, E.C., A.O., D.T. and V.O.; data curation, E.C., A.O., D.T. and V.O.; writing-original draft preparation, E.C., A.O., D.T. and V.O.; writing-review and editing, V.O.; supervision, V.O. All authors have read and agreed to the published version of the manuscript.

Funding: This research received no external funding.

Conflicts of Interest: The authors declare no conflict of interest.

\begin{abstract}
Abbreviations
ABTS: 2,2-azino-bis-3-ethylbenzothiazoline-6-sulfonic acid radical, ASE: accelerated solvent extraction, BBD: Box-Behnken design, CA: carnosic acid, CAF: caffeic acid, CAR: carvacrol, CCD: Central composite design, CHWE: conventional hot water extraction, COH: carnosol, CSE: conventional solvent extraction DPPH: 1,1-diphenyl-2-picrylhydrazyl radical, EO: essential oil, HPLC: high pressure liquid chromatography, FRAP: ferric reducing antioxidant power, GAE: gallic acid equivalents, MAE: microwave assisted extraction, OA: oleanolic acid, OHAE: Ohmic heating assisted extraction, ORAC: oxygen radical absorbance capacity, PLE: pressurized liquid extraction, PHWE: pressurized hot water extraction, ProtCa: protocatechuic acid, PWE: pressurized water extraction, RA: rosmarinic acid, RSM: response surface methodology, SFE: supercritical fluid extraction, SFME: solid free microwave extraction, SWE: subcritical water extraction, TEAC: trolox equivalent antioxidant capacity, TPC: total phenolic content, UA: ursolic acid, UAE: ultrasound assisted extraction, WEPO: pressurized water extraction with particle on-line formation.
\end{abstract}

\title{
References
}

1. Kebede, M.; Admassu, S. Application of antioxidants in food processing industry: Options to improve the extraction yields and market value of natural products. Adv. Food Technol. Nutr. Sci. Open J. 2019, 5, 38-49. [CrossRef]

2. Oreopoulou, A.; Papavassilopoulou, E.; Bardouki, H.; Vamvakias, M.; Bimpilas, A.; Oreopoulou, V. Antioxidant recovery from hydrodistillation residues of selected Lamiaceae species by alkaline extraction. J. Appl. Res. Med. Aromat. Plants 2018, 8, 83-89. [CrossRef]

3. Wollinger, A.; Perrin, E.; Chahboun, J.; Jeannot, V.; Touraud, D.; Kunz, W. Antioxidant activity of hydro distillation water residues from Rosmarinus officinalis L. leaves determined by DPPH assays. C. R. Chim. 2016, 19, 754-765. [CrossRef]

4. Allaf, T.; Tomao, V.; Ruiz, K.; Bachari, K.; El Maataoui, M.; Chemat, F. Deodorization by instant controlled pressure drop autovaporization of rosemary leaves prior to solvent extraction of antioxidants. LWT Food Sci. Technol. 2013, 51, 111-119. [CrossRef]

5. Angioni, A.; Barra, A.; Cereti, E.; Barile, D.; Coïson, J.D.; Arlorio, M.; Dessi, S.; Coroneo, V.; Cabras, P. Chemical composition, plant genetic differences, antimicrobial and antifungal activity investigation of the essential oil of Rosmarinus officinalis L. J. Agric. Food Chem. 2004, 52, 3530-3535. [CrossRef]

6. Zaouali, Y.; Bouzaine, T.; Boussaid, M. Essential oils composition in two Rosmarinus officinalis L. varieties and incidence for antimicrobial and antioxidant activities. Food Chem. Toxicol. 2010, 48, 3144-3152. [CrossRef]

7. Melito, S.; Petretto, G.L.; Chahine, S.; Pintore, G.; Chessa, M. Seasonal variation of essential oil in Rosmarinus officinalis leaves in Sardinia. Nat. Prod. Commun. 2019, 14, 1934578X1986400. [CrossRef] 
8. Santana-Méridas, O.; Polissiou, M.; Izquierdo-Melero, M.E.; Astraka, K.; Tarantilis, P.A.; Herraiz-Peñalver, D.; Sánchez-Vioque, R. Polyphenol composition, antioxidant and bioplaguicide activities of the solid residue from hydrodistillation of Rosmarinus officinalis L. Ind. Crop. Prod. 2014, 59, 125-134. [CrossRef]

9. Navarrete, A.; Herrero, M.; Martín, A.; Cocero, M.J.; Ibáñez, E. Valorization of solid wastes from essential oil industry. J. Food Eng. 2011, 104, 196-201. [CrossRef]

10. Moreno, S.; Scheyer, T.; Romano, C.S.; Vojnov, A.A. Antioxidant and antimicrobial activities of rosemary extracts linked to their polyphenol composition. Free Radic. Res. 2006, 40, 223-231. [CrossRef]

11. Andrade, J.M.; Faustino, C.; Garcia, C.; Ladeiras, D.; Reis, C.P.; Rijo, P. Rosmarinus officinalis L.: An update review of its phytochemistry and biological activity. Future Sci. OA 2018, 4, FSO283. [CrossRef]

12. De Oliveira, J.R.; Camargo, S.E.A.; de Oliveira, L.D. Rosmarinus officinalis L. (rosemary) as therapeutic and prophylactic agent. J. Biomed. Sci 2019, 26, 5. [CrossRef]

13. Moore, J.; Yousef, M.; Tsiani, E. Anticancer effects of rosemary (Rosmarinus officinalis L.) extract and rosemary extract polyphenols. Nutrients 2016, 8, 731. [CrossRef]

14. Ribeiro-Santos, R.; Carvalho-Costa, D.; Cavaleiro, C.; Costa, H.S.; Albuquerque, T.G.; Castilho, M.C.; Sanches-Silva, A. A novel insight on an ancient aromatic plant: The rosemary (Rosmarinus officinalis L.). Trends Food Sci. Technol 2015, 45, 355-368. [CrossRef]

15. Birtić, S.; Dussort, P.; Pierre, F.X.; Bily, A.C.; Roller, M. Carnosic acid. Phytochemistry 2015, 115, 9-19. [CrossRef]

16. Zhang, Y.; Smuts, J.P.; Dodbiba, E.; Rangarajan, R.; Lang, J.C.; Armstrong, D.W. Degradation study of carnosic acid, carnosol, rosmarinic acid, and rosemary extract (Rosmarinus officinalis L.) assessed using HPLC. J. Agric. Food Chem 2012, 60, 9305-9314. [CrossRef]

17. Mena, P.; Cirlini, M.; Tassotti, M.; Herrlinger, K.A.; Dall'Asta, C.; Del Rio, D. Phytochemical profiling of flavonoids, phenolic acids, terpenoids, and volatile fraction of a rosemary (Rosmarinus officinalis L.) extract. Molecules 2016, 21, 1576. [CrossRef]

18. Bernatoniene, J.; Cizauskaite, U.; Ivanauskas, L.; Jakstas, V.; Kalveniene, Z.; Kopustinskiene, D.M. Novel approaches to optimize extraction processes of ursolic, oleanolic and rosmarinic acids from Rosmarinus officinalis leaves. Ind. Crop. Prod. 2016, 84, 72-79. [CrossRef]

19. Borrás Linares, I.; Arráez-Román, D.; Herrero, M.; Ibáñez, E.; Segura-Carretero, A.; Fernández-Gutiérrez, A. Comparison of different extraction procedures for the comprehensive characterization of bioactive phenolic compounds in Rosmarinus officinalis by reversed-phase high-performance liquid chromatography with diode array detection coupled to electrospray time-of-flight mass spectrometry. J. Chromatogr. A 2011, 1218, 7682-7690. [CrossRef]

20. Borrás-Linares, I.; Stojanović, Z.; Quirantes-Piné, R.; Arráez-Román, D.; Švarc-Gajić, J.; Fernández-Gutiérrez, A.; Segura-Carretero, A. Rosmarinus officinalis leaves as a natural source of bioactive compounds. Int. J. Mol. Sci. 2014, 15, 20585-20606. [CrossRef]

21. Psarrou, I.; Oreopoulou, A.; Tsimogiannis, D.; Oreopoulou, V. Extraction Kinetics of Phenolic Antioxidants from the Hydro Distillation Residues of Rosemary and Effect of Pretreatment and Extraction Parameters. Molecules 2020, 25, 4520. [CrossRef] [PubMed]

22. De AR Oliveira, G.; de Oliveira, A.E.; da Conceição, E.C.; Leles, M.I. Multiresponse optimization of an extraction procedure of carnosol and rosmarinic and carnosic acids from rosemary. Food Chem. 2016, 211, 465-473. [CrossRef] [PubMed]

23. Rodríguez-Rojo, S.; Visentin, A.; Maestri, D.; Cocero, M.J. Assisted extraction of rosemary antioxidants with green solvents. J. Food Eng. 2012, 109, 98-103. [CrossRef]

24. Albu, S.; Joyce, E.; Paniwnyk, L.; Lorimer, J.P.; Mason, T.J. Potential for the use of ultrasound in the extraction of antioxidants from Rosmarinus officinalis for the food and pharmaceutical industry. Ultrason. Sonochem. 2004, 11, 261-265. [CrossRef]

25. Bellumori, M.; Innocenti, M.; Binello, A.; Boffa, L.; Mulinacci, N.; Cravotto, G. Selective recovery of rosmarinic and carnosic acids from rosemary leaves under ultrasound-and microwave-assisted extraction procedures. C. R. Chim. 2016, 19, 699-706. [CrossRef]

26. Paniwnyk, L.; Cai, H.; Albu, S.; Mason, T.J.; Cole, R. The enhancement and scale up of the extraction of anti-oxidants from Rosmarinus officinalis using ultrasound. Ultrason. Sonochem. 2009, 16, 287-292. [CrossRef]

27. Mulinacci, N.; Innocenti, M.; Bellumori, M.; Giaccherini, C.; Martini, V.; Michelozzi, M. Storage method, drying processes and extraction procedures strongly affect the phenolic fraction of rosemary leaves: An HPLC/DAD/MS study. Talanta 2011, 85, 167-176. [CrossRef]

28. Kasparavičienè, G.; Ramanauskienė, K.; Savickas, A.; Velžienė, S.; Kazlauskienė, D.; Ragažinskienė, O.; Ivanauskas, K. Evaluation of total phenolic content and antioxidant activity of different Rosmarinus officinalis L. ethanolic extracts. Biologija 2013, 59, 39-44. [CrossRef]

29. Jacotet-Navarro, M.; Rombaut, N.; Fabiano-Tixier, A.S.; Danguien, M.; Bily, A.; Chemat, F. Ultrasound versus microwave as green processes for extraction of rosmarinic, carnosic and ursolic acids from rosemary. Ultrason. Sonochem. 2015, 27, 102-109. [CrossRef]

30. Hossain, M.B.; Barry-Ryan, C.; Martin-Diana, A.B.; Brunton, N.P. Optimisation of accelerated solvent extraction of antioxidant compounds from rosemary (Rosmarinus officinalis L.), marjoram (Origanum marjorana L.) and oregano (Origanum vulgare L.) using response surface methodology. Food Chem. 2011, 126, 339-346. [CrossRef]

31. Hosseini, H.; Shadi, B.; Elham, Y.H.; Elham, G.M. Optimization of heat- and ultrasound-assisted extraction of polyphenols from dried rosemary leaves using response surface methodology. J. Food Process. Preserv. 2018, 42, e13778. [CrossRef]

32. Proestos, C.; Komaitis, M. Application of microwave-assisted extraction to the fast extraction of plant phenolic compounds. LWT Food Sci. Technol. 2008, 41, 652-659. [CrossRef]

33. Švarc-Gajić, J.; Stojanović, Z.; Carretero, A.S.; Román, D.A.; Borrás, I.; Vasiljević, I. Development of a microwave-assisted extraction for the analysis of phenolic compounds from Rosmarinus officinalis. J. Food Eng. 2013, 119, 525-532. [CrossRef] 
34. Herrero, M.; Plaza, M.; Cifuentes, A.; Ibáñez, E. Green processes for the extraction of bioactives from Rosemary: Chemical and functional characterization via ultra-performance liquid chromatography-tandem mass spectrometry and in-vitro assays. $J$. Chromatogr. A 2010, 1217, 2512-2520. [CrossRef]

35. Bunghez, F.; Rotar, A.; Vodnar, D.C.; Catunescu, G.M.; Socaciu, C. Comparative evaluation of phenolics' profile and recovery in spray dried powders obtained from rosemary and oregano extracts in relation to their antibacterial activity in vitro. Rom. Biotechnol. Lett. 2016, 22, 11992.

36. Shirsath, S.R.; Sonawane, S.H.; Gogate, P.R. Intensification of extraction of natural products using ultrasonic irradiations-A review of current status. Chem. Eng. Process. 2012, 53, 10-23. [CrossRef]

37. Okoh, O.O.; Sadimenko, A.P.; Afolayan, A.J. Comparative evaluation of the antibacterial activities of the essential oils of Rosmarinus officinalis L. obtained by hydrodistillation and solvent free microwave extraction methods. Food Chem. 2010, 120, 308-312. [CrossRef]

38. Li, Y.; Fabiano-Tixier, A.S.; Vian, M.A.; Chemat, F. Solvent-Free microwave extraction of bioactive compounds provides a tool for green analytical chemistry. Trends Anal. Chem. 2013, 47, 1-11. [CrossRef]

39. Herrero, M.; Arráez-Román, D.; Segura, A.; Kenndler, E.; Gius, B.; Raggi, M.A.; Cifuentes, A. Pressurized liquid extractioncapillary electrophoresis-mass spectrometry for the analysis of polar antioxidants in rosemary extracts. J. Chromatogr. A 2005, 1084, 54-62. [CrossRef]

40. Bicchi, C.; Binello, A.; Rubiolo, P. Determination of phenolic diterpene antioxidants in rosemary (Rosmarinus officinalis L.) with different methods of extraction and analysis. Phytochem. Anal. 2000, 11, 236-242. [CrossRef]

41. Zabot, G.L.; Moraes, M.N.; Carvalho, P.I.; Meireles, M.A.A. New proposal for extracting rosemary compounds: Process intensification and economic evaluation. Ind. Crop. Prod. 2015, 77, 758-771. [CrossRef]

42. Rodríguez-Meizoso, I.; Castro-Puyana, M.; Börjesson, P.; Mendiola, J.A.; Turner, C.; Ibáñez, E. Life cycle assessment of green pilot-scale extraction processes to obtain potent antioxidants from rosemary leaves. J. Supercrit. Fluids 2012, 72, 205-212. [CrossRef]

43. Zu, G.; Zhang, R.; Yang, L.; Ma, C.; Zu, Y.; Wang, W.; Zhao, C. Ultrasound-Assisted extraction of carnosic acid and rosmarinic acid using ionic liquid solution from Rosmarinus officinalis. Int. J. Mol. Sci. 2012, 13, 11027-11043. [CrossRef]

44. Papageorgiou, V.; Mallouchos, A.; Komaitis, M. Investigation of the antioxidant behavior of air-and freeze-dried aromatic plant materials in relation to their phenolic content and vegetative cycle. J. Agric. Food Chem. 2008, 56, 5743-5752. [CrossRef]

45. Meziane-Assami, D.; Tomao, V.; Ruiz, K.; Meklati, B.; Chemat, F. Geographical differentiation of rosemary based on GC/MS and fast HPLC analyses. Food Anal. Methods 2013, 6, 282-288. [CrossRef]

46. Yeddes, W.; Chalghoum, A.; Aidi-Wannes, W.; Ksouri, R.; Saidani Tounsi, M. Effect of bioclimatic area and season on phenolics and antioxidant activities of rosemary (Rosmarinus officinalis L.) leaves. J. Essent. Oil Res. 2019, 31, 432-443. [CrossRef]

47. Hadi Soltanabad, M.; Bagherieh-Najjar, M.B.; Mianabadi, M. Seasonal variations in carnosic acid content of rosemary correlates with anthocyanins and soluble sugars. J. Med. Plants Prod. 2018, 7, 163-171. [CrossRef]

48. Fiume, M.M.; Bergfeld, W.F.; Belsito, D.V.; Hill, R.A.; Klaassen, C.D.; Liebler, D.C.; Heldreth, B. Safety assessment of Rosmarinus officinalis (rosemary)-derived ingredients as used in cosmetics. Int. J. Toxicol. 2018, 37, 12S-50S. [CrossRef]

49. Lee, C.J.; Chen, L.G.; Chang, T.L.; Ke, W.M.; Lo, Y.F.; Wang, C.C. The correlation between skin-care effects and phytochemical contents in Lamiaceae plants. Food Chem. 2011, 124, 833-841. [CrossRef]

50. Piñeros-Hernandez, D.; Medina-Jaramillo, C.; López-Córdoba, A.; Goyanes, S. Edible cassava starch films carrying rosemary antioxidant extracts for potential use as active food packaging. Food Hydrocoll. 2017, 63, 488-495. [CrossRef]

51. Choulitoudi, E.; Ganiari, S.; Tsironi, T.; Ntzimani, A.; Tsimogiannis, D.; Taoukis, P.; Oreopoulou, V. Edible coating enriched with rosemary extracts to enhance oxidative and microbial stability of smoked eel fillets. Food Packag. Shelf Life 2017, 12, 107-113. [CrossRef]

52. Oreopoulou, V.; Tsironi, T. Plant antioxidants and antimicrobials in edible and non-edible active packaging films. In Plant Antioxidants and Health; Ekiert, H.M., Ramawat, K.G., Arora, J., Eds.; Reference Series in Phytochemistry; Springer: Cham, Switzerland, 2021. [CrossRef]

53. Global Rosemary Extract Market. Available online: https://www.360researchreports.com/global-rosemary-extract-market-1407 6077 (accessed on 10 April 2020).

54. Couto, R.O.; Conceição, E.C.; Chaul, L.T.; Oliveira, E.M.; Martins, F.S.; Bara, M.T.F.; Paula, J.R. Spray-Dried rosemary extracts: Physicochemical and antioxidant properties. Food Chem. 2012, 131, 99-105. [CrossRef]

55. Chaul, L.T.; Conceicão, E.C.; Bara, M.-T.F.; Paula, J.R.; Couto, R.O. Engineering spray-dried rosemary extracts with improved physicomechanical properties: A design of experiments issue. Rev. Bras. Farmacogn. 2017, 27, 236-244. [CrossRef]

56. Spyridopoulou, K.; Fitsiou, E.; Bouloukosta, E.; Tiptiri-Kourpeti, A.; Vamvakias, M.; Oreopoulou, A.; Papavassilopoulou, E.; Pappa, A.; Chlichlia, K. Extraction, Chemical Composition, and Anticancer Potential of Origanum onites L. Essential Oil. Molecules 2019, 24, 2612. [CrossRef]

57. Marrelli, M.; Conforti, F.; Formisano, C.; Rigano, D.; Arnold, N.A.; Menichini, F.; Senatore, F. Composition, antibacterial, antioxidant and antiproliferative activities of essential oils from three Origanum species growing wild in Lebanon and Greece. Nat. Prod. Res. 2016, 30, 735-739. [CrossRef]

58. Castilho, P.; Savluchinske-Feio, S.; Weinhold, T.; Gouveia-Figueira, S. Evaluation of the antimicrobial and antioxidant activities of essential oils, extracts and their main components from oregano from Madeira Island, Portugal. Food Control 2012, 23, 552-558. [CrossRef] 
59. Nabavi, S.M.; Nabavi, S.F.; Loizzo, M.R.; Tundis, R.; Devi, K.P.; Silva, A.S. Food Additives and Human Health, 1st ed.; Bentham Science Publishers: Sharjah, United Arab Emirates, 2020; p. 23.

60. Gutiérrez-Grijalva, E.P.; Picos-Salas, M.A.; Leyva-López, N.; Criollo-Mendoza, M.S.; Vazquez-Olivo, G.; Heredia, J.B. Flavonoids and Phenolic Acids from Oregano: Occurrence, Biological Activity and Health Benefits. Plants 2017, 7, 2. [CrossRef]

61. Kumar, M.; Bhardwaj, D. The underexploited biotechnology of overexploited Origanum species: Status, knowledge gaps, prospects and potential. Plant Sci. Today 2020, 7, 512-522. [CrossRef]

62. González, M.D.; Lanzelotti, P.L.; Luis, C.M. Chemical fingerprinting by HPLC-DAD to differentiate certain subspecies of Origanum vulgare L. Food Anal. Methods 2017, 10, 1460-1468. [CrossRef]

63. Zhang, X.L.; Guo, Y.S.; Wang, C.H.; Li, G.Q.; Xu, J.J.; Chung, H.Y.; Ye, W.C.; Li, Y.L.; Wang, G.C. Phenolic compounds from Origanum vulgare and their antioxidant and antiviral activities. Food Chem. 2014, 152, 300-306. [CrossRef]

64. Oreopoulou, A.; Goussias, G.; Tsimogiannis, D.; Oreopoulou, V. Hydro-alcoholic Extraction Kinetics of Phenolics from Oregano: Optimization of the Extraction Parameters. Food Bioprod. Process. 2020, 123, 389. [CrossRef]

65. Baranauskaitè, J.; Jakštas, V.; Ivanauskas, L.; Kopustinskienè, D.M.; Drakšienè, G.; Masteikova, R.; Bernatonienė, J. Optimization of carvacrol, rosmarinic, oleanolic and ursolic acid extraction from oregano herbs (Origanum onites L., Origanum vulgare spp. hirtum and Origanum vulgare L.). Nat. Prod. Res. 2016, 30, 672-674. [CrossRef]

66. Spiridon, I.; Colceru, S.; Anghel, N.; Teaca, C.A.; Bodirlau, R.; Armatu, A. Antioxidant capacity and total phenolic contents of oregano (Origanum vulgare), lavender (Lavandula angustifolia) and lemon balm (Melissa officinalis) from Romania. Nat. Prod. Res. 2011, 25, 1657-1661. [CrossRef]

67. Bendini, A.; Gallina Toschi, T.; Lercker, G. Antioxidant activity of oregano (Origanum vulgare L.) leaves. Ital. J. Food Sci. 2002, 14, 17-24.

68. Cervato, G.; Carabelli, M.; Gervasio, S.; Cittera, A.; Cazzola, R.; Benvenuto, C. Antioxidant properties of oregano (Origanum vulgare) leaf extract. J. Food Biochem. 2000, 24, 453-465. [CrossRef]

69. Martins, N.; Barros, L.; Santos-Buelga, C.; Henriques, M.; Silva, S.; Ferreira, I.C. Decoction, infusion and hydroalcoholic extract of Origanum vulgare L.: Different performances regarding bioactivity and phenolic compounds. Food Chem. 2014, 158, 73-80. [CrossRef]

70. Ličina, B.; Stefanovic, O.; Vasić, S.; Radojevic, I.; Dekic, M.; Čomić, L. Biological activities of the extracts from wild growing Origanum vulgare L. Food Control 2013, 33, 498-504. [CrossRef]

71. Hossain, M.B.; Rai, D.K.; Brunton, N.P.; Martin-Diana, A.B.; Barry-Ryan, C. Characterization of phenolic composition in Lamiaceae spices by LC-ESI-MS/MS. J. Agric. Food Chem. 2010, 58, 10576-10581. [CrossRef]

72. Skoula, M.; Grayer, R.; Kite, G.; Veitch, N. Exudate flavones and flavanones in Origanum species and their interspecific variation. Biochem. Syst. Ecol. 2008, 36, 646-654. [CrossRef]

73. Koukoulitsa, C.; Karioti, A.; Bergonzi, M.; Pescitelli, G.; Di Bari, L.; Skaltsa, H. Polar Constituents from the Aerial Parts of Origanum vulgare L. ssp. Hirtum Growing Wild in Greece. J. Agric. Food Chem. 2006, 54, 5388-5392. [CrossRef]

74. Milevskaya, V.V.; Prasad, S.; Temerdashev, Z.A. Extraction and chromatographic determination of phenolic compounds from medicinal herbs in the Lamiaceae and Hypericaceae families: A review. Microchem. J. 2019, 145, 1036-1049. [CrossRef]

75. Dorman, H.J.; Bachmayer, O.; Kosar, M.; Hiltunen, R. Antioxidant properties of aqueous extracts from selected Lamiaceae species grown in Turkey. J. Agric. Food Chem. 2004, 52, 762-770. [CrossRef] [PubMed]

76. Gonçalves, S.; Moreira, E.; Grosso, C.; Andrade, P.B.; Valentão, P.; Romano, A. Phenolic profile, antioxidant activity and enzyme inhibitory activities of extracts from aromatic plants used in Mediterranean diet. J. Food Sci. Technol. 2017, 54, 219-227. [CrossRef] [PubMed]

77. Exarchou, V.; Nenadis, N.; Tsimidou, M.; Gerothanassis, I.P.; Troganis, A.; Boskou, D. Antioxidant activities and phenolic composition of extracts from Greek oregano, Greek sage, and summer savory. J. Agric. Food Chem. 2002, 50, 5294-5299. [CrossRef]

78. Majeed, M.; Hussain, A.I.; Chatha, S.A.S.; Khosa, M.K.K.; Kamal, G.M.; Kamal, M.A.; Zhang, X.; Liu, M. Optimization protocol for the extraction of antioxidant components from Origanum vulgare leaves using response surface methodology. Saudi J. Biol. Sci. 2016, 23, 389-396. [CrossRef]

79. Skendi, A.; Irakli, M.; Chatzopoulou, P. Analysis of phenolic compounds in Greek plants of Lamiaceae family by HPLC. J. Appl. Res. Med. Aromat. Plants 2017, 6, 62-69. [CrossRef]

80. Yan, F.; Azizi, A.; Janke, S.; Schwarz, M.; Zeller, S.; Honermeier, B. Antioxidant capacity variation in the oregano (Origanum vulgare L.) collection of the German National Genebank. Ind. Crop. Prod. 2016, 92, 19-25. [CrossRef]

81. Balkan, B.; Balkan, S.; Aydogdu, H.; Guler, N.; Ersoy, H.; Askin, B. Evaluation of antioxidant activities and antifungal activity of different plants species against pink mold rot-causing Trichothecium roseum. Arab. J. Sci. Eng. 2017, 42, 2279-2289. [CrossRef]

82. Bower, A.M.; Hernandez, L.M.R.; Berhow, M.A.; de Mejia, E.G. Bioactive compounds from culinary herbs inhibit a molecular target for type 2 diabetes management, dipeptidyl peptidase IV. J. Agric. Food Chem. 2014, 62, 6147-6158. [CrossRef]

83. Triantaphyllou, K.; Blekas, G.; Boskou, D. Antioxidative properties of water extracts obtained from herbs of the species Lamiaceae. Int. J. Food Sci. Nutr. 2001, 52, 313-317. [CrossRef]

84. Rodríguez-Meizoso, I.; Marin, F.R.; Herrero, M.; Señorans, F.J.; Reglero, G.; Cifuentes, A.; Ibáñez, E. Subcritical water extraction of nutraceuticals with antioxidant activity from oregano. Chemical and functional characterization. J. Pharm. Biomed. Anal. 2006, 41, 1560-1565. [CrossRef] 
85. Omar, J.; Alonso, I.; Garaikoetxea, A.; Etxebarria, N. Optimization of focused ultrasound extraction and supercritical fluid extraction of volatile compounds and antioxidants from aromatic plants. Food Anal. Methods 2013, 6, 1611-1620. [CrossRef]

86. Cavero, S.; García-Risco, M.R.; Marín, F.R.; Jaime, L.; Santoyo, S.; Javier Señoráns, F.; Reglero, G.; Ibañez, E. Supercritical fluid extraction of antioxidant compounds from oregano: Chemical and functional characterization via LC-MS and in vitro assays. J. Supercrit. Fluids 2006, 38, 62-69. [CrossRef]

87. Skotti, E.; Anastasaki, E.; Kanellou, G.; Polissiou, M.; Tarantilis, P.A. Total phenolic content, antioxidant activity and toxicity of aqueous extracts from selected Greek medicinal and aromatic plants. Ind. Crop. Prod. 2014, 53, 46-54. [CrossRef]

88. Stamenic, M.; Vulic, J.; Djilas, S.; Misic, D.; Tadic, V.; Petrovic, S.; Zizovic, I. Free-Radical scavenging activity and antibacterial impact of Greek oregano isolates obtained by SFE. Food Chem. 2014, 165, 307-315. [CrossRef]

89. Capecka, E.; Mareczek, A.; Leja, M. Antioxidant activity of fresh and dry herbs of some Lamiaceae species. Food Chem. 2005, 93, 223-226. [CrossRef]

90. Hossain, M.B.; Barry-Ryan, C.; Martin-Diana, A.B.; Brunton, N.P. Effect of drying method on the antioxidant capacity of six Lamiaceae herbs. Food Chem. 2010, 123, 85-91. [CrossRef]

91. Oregano Extract Market—Global Industry Analysis, Size, Share, Growth, Trends, and Forecast 2017-2025. Available online: https: / / www.transparencymarketresearch.com/oregano-extract-market.html (accessed on 15 March 2021).

92. de Torre, M.P.; Vizmanos, J.L.; Cavero, R.Y.; Calvo, M.I. Improvement of antioxidant activity of oregano (Origanum vulgare L.) with an oral pharmaceutical form. Biomed. Pharmacother. 2020, 129, 110424. [CrossRef]

93. Ganiari, S.; Choulitoudi, E.; Oreopoulou, V. Edible and active films and coatings as carriers of natural antioxidants for lipid food. Trends Food Sci. Technol. 2017, 68, 70-82. [CrossRef]

94. Ball, P.W.; Getliffe, F. Clinopodium L. In Flora Europaea; Tutin, T.G., Heywood, V.H., Burges, N.A., Moore, D.M., Valentine, D.H., Walters, S.M., Webb, D.A., Eds.; Cambridge University Press: Cambridge, UK, 1972; pp. 166-167.

95. Tepe, B.; Cilkiz, M. A pharmacological and phytochemical overview on Satureja. Pharm. Biol. 2016, 54, 375-412. [CrossRef]

96. Saab, A.M.; Lampronti, I.; Finotti, A.; Borgatti, M.; Gambari, R.; Esseily, F.; Safi, S.; Diab-Assaf, M.; Rabenau, H.; Cinalt, J.; et al. In vitro evaluation of the biological activity of Lebanese medicinal plants extracts against herpes simplex virus type 1. Minerva Biotechnol. 2012, 24, 117-121.

97. Öztürk, M. Anticholinesterase and antioxidant activities of Savoury (Satureja thymbra L.) with identified major terpenes of the essential oil. Food Chem. 2012, 134, 48-54. [CrossRef]

98. Loizzo, M.R.; Saab, A.M.; Tundis, R.; Statti, G.A.; Menichini, F.; Lampronti, I.; Gambari, R.; Cinalt, J.; Doerr, H.W. Phytochemical analysis and in vitro antiviral activities of the essential oils of seven Lebanon species. Chem. Biodivers. 2008, 5, 461-470. [CrossRef]

99. Choulitoudi, E.; Bravou, K.; Bimpilas, A.; Tsironi, T.; Tsimogiannis, D.; Taoukis, P.; Oreopoulou, V. Antimicrobial and antioxidant activity of Satureja thymbra in gilthead seabream fillets edible coating. Food Bioprod. Process. 2016, 100, 570-577. [CrossRef]

100. Skoula, M.; Grayer, R.J.; Kite, G.C. Surface flavonoids in Satureja thymbra and Satureja spinosa (Lamiaceae). Biochem. Syst. Ecol. 2005, 33, 541-544. [CrossRef]

101. Tsimogiannis, D.; Choulitoudi, E.; Bimpilas, A.; Mitropoulou, G.; Kourkoutas, Y.; Oreopoulou, V. Exploitation of the biological potential of Satureja thymbra essential oil and distillation by-products. J. Appl. Res. Med. Aromat. Plants 2017, 4, 12-20. [CrossRef]

102. López-Cobo, A.; Gómez-Caravaca, A.M.; Švarc-Gajić, J.; Segura-Carretero, A.; Fernández-Gutiérrez, A. Determination of phenolic compounds and antioxidant activity of a Mediterranean plant: The case of Satureja montana ssp. kitaibelii. J. Funct. Foods 2015, 18, 1167-1178. [CrossRef]

103. Yin, H.; Fretté , X.C.; Christensen, L.P.; Grevsen, K. Chitosan oligosaccharides promote the content of polyphenols in Greek oregano (Origanum vulgare ssp. hirtum). J. Agric. Food Chem. 2012, 60, 136-143. [CrossRef]

104. Kemertelidze, É.P.; Sagareishvili, T.G.; Syrov, V.N.; Khushbaktova, Z.A. Chemical composition and pharmacological activity of garden savory (Satureja hortensis L.) occurring in Georgia. Pharm. Chem. J. 2004, 38, 319-322. [CrossRef]

105. Zgórka, G.; Głowniak, K. Variation of free phenolic acids in medicinal plants belonging to the Lamiaceae family. J. Pharm. Biomed. Anal. 2001, 26, 79-87. [CrossRef]

106. Jancheva, M.; Grigorakis, S.; Loupassaki, S.; Makris, D.P. Optimised extraction of antioxidant polyphenols from Satureja thymbra using newly designed glycerol-based natural low-transition temperature mixtures (LTTMs). J. Appl. Res. Med. Aromat. Plants 2017, 6, 31-40. [CrossRef]

107. Özkan, G.; Özcan, M.M. Antioxidant activity of some medicinal plant extracts on oxidation of olive oil. J. Food Meas. Charact. 2017, 11, 812-817. [CrossRef]

108. Choulitoudi, E.; Xristou, M.; Tsimogiannis, D.; Oreopoulou, V. The effect of temperature on the phenolic content and oxidative stability of o/w emulsions enriched with natural extracts from Satureja thymbra. Food Chem. 2021, 349, 129206. [CrossRef]

109. Choulitoudi, E.; Velliopoulou, A.; Tsimogiannis, D.; Oreopoulou, V. Effect of active packaging with Satureja thymbra extracts on the oxidative stability of fried potato chips. Food Packag. Shelf Life 2020, 23, 100455. [CrossRef]

110. Shakeri, A.; Sahebkar, A.; Javadi, B. Melissa officinalis L.-A review of its traditional uses, phytochemistry and pharmacology. J. Ethnopharmacol. 2016, 188, 204-228. [CrossRef]

111. Maleš, Ž.; Antolić, A.; Babić, I.; Jurić, S.; Bojić, M. Quantitative analysis of phenolic acids and antiplatelet activity of Melissa officinalis leaf extracts. Nat. Prod. Commun. 2017, 12. [CrossRef]

112. Poyato, C.; Navarro-Blasco, I.; Calvo, M.I.; Cavero, R.Y.; Astiasarán, I.; Ansorena, D. Oxidative stability of O/W and W/O/W emulsions: Effect of lipid composition and antioxidant polarity. Food Res. Int. 2013, 51, 132-140. [CrossRef] 
113. Awad, R.; Muhammad, A.; Durst, T.; Trudeau, V.L.; Arnason, J.T. Bioassay-Guided fractionation of lemon balm (Melissa officinalis L.) using an in vitro measure of GABA transaminase activity. Phytother. Res. 2009, 23, 1075-1081. [CrossRef]

114. Tantry, M.A.; Bhat, G.A.; Idris, A.; Dar, J.A.; Yousef Al Omar, S.; Masoodi, K.Z.; Ganai, B.A.; Kamili, A.N.; Shawl, A.S. Sulfated triterpenes from Lemon balm. Helv. Chim. Acta 2014, 97, 1497-1506. [CrossRef]

115. Encalada, M.A.; Hoyos, K.M.; Rehecho, S.; Berasategi, I.; de Ciriano, M.G.; Ansorena, D.; Astiasarán, I.; Navarro-Blasco, I.; Cavero, R.Y.; Calvo, M.I. Anti-Proliferative effect of Melissa officinalis on human colon cancer cell line. Plant Foods Hum. Nutr. 2011, 66, 328-334. [CrossRef]

116. Pereira, R.P.; Boligon, A.A.; Appel, A.S.; Fachinetto, R.; Ceron, C.S.; Tanus-Santos, J.E.; Athayde, M.L.; Rocha, J.B.T. Chemical composition, antioxidant and anticholinesterase activity of Melissa officinalis. Ind. Crop. Prod. 2014, 53, 34-45. [CrossRef]

117. Mencherini, T.; Picerno, P.; Scesa, C.; Aquino, R. Triterpene, antioxidant, and antimicrobial compounds from Melissa officinalis. J. Nat. Prod. 2007, 70, 1889-1894. [CrossRef]

118. Arceusz, A.; Wesolowski, M. Quality consistency evaluation of Melissa officinalis L. commercial herbs by HPLC fingerprint and quantitation of selected phenolic acids. J. Pharm. Biomed. Anal. 2013, 83, 215-220. [CrossRef]

119. Caniova, A.; Brandsteterova, E. HPLC analysis of phenolic acids in Melissa officinalis. J. Liq. Chromatogr. Relat. Technol. 2001, 24, 2647-2659. [CrossRef]

120. Peev, G.; Penchev, P.; Peshev, D.; Angelov, G. Solvent extraction of rosmarinic acid from lemon balm and concentration of extracts by nanofiltration: Effect of plant pre-treatment by supercritical carbon dioxide. Chem. Eng. Res. Des. 2011, 89, $2236-2243$. [CrossRef]

121. Luño, V.; Gil, L.; Olaciregui, M.; González, N.; Jerez, R.A.; De Blas, I. Rosmarinic acid improves function and in vitro fertilising ability of boar sperm after cryopreservation. Cryobiology 2014, 69, 157-162. [CrossRef]

122. Saltas, D.; Pappas, C.S.; Daferera, D.; Tarantilis, P.A.; Polissiou, M.G. Direct determination of rosmarinic acid in Lamiaceae herbs using diffuse reflectance infrared Fourier transform spectroscopy (DRIFTS) and chemometrics. J. Agric. Food Chem. 2013, 61, 3235-3241. [CrossRef] [PubMed]

123. Lee, J. Caffeic acid derivatives in dried Lamiaceae and Echinacea purpurea products. J. Funct. Foods 2010, 2, 158-162. [CrossRef]

124. Barros, L.; Dueñas, M.; Dias, M.I.; Sousa, M.J.; Santos-Buelga, C.; Ferreira, I.C. Phenolic profiles of cultivated, in vitro cultured and commercial samples of Melissa officinalis L. infusions. Food Chem. 2013, 136, 1-8. [CrossRef] [PubMed]

125. Fecka, I.; Turek, S. Determination of water-soluble polyphenolic compounds in commercial herbal teas from Lamiaceae: Peppermint, melissa, and sage. J. Agric. Food Chem. 2007, 55, 10908-10917. [CrossRef]

126. Milevskaya, V.V.; Temerdashev, Z.A.; Butyl'skaya, T.S.; Kiseleva, N.V. Determination of phenolic compounds in medicinal plants from the Lamiaceae family. J. Anal. Chem. 2017, 72, 342-348. [CrossRef]

127. Miron, T.L.; Herrero, M.; Ibáñez, E. Enrichment of antioxidant compounds from lemon balm (Melissa officinalis) by pressurized liquid extraction and enzyme-assisted extraction. J. Chromatogr. A 2013, 1288, 1-9. [CrossRef]

128. Boneza, M.M.; Niemeyer, E.D. Cultivar affects the phenolic composition and antioxidant properties of commercially available lemon balm (Melissa officinalis L.) varieties. Ind. Crop. Prod. 2018, 112, 783-789. [CrossRef]

129. Sentkowska, A.; Biesaga, M.; Pyrzynska, K. Polyphenolic composition and antioxidative properties of lemon balm (Melissa officinalis L.) extract affected by different brewing processes. Int. J. Food Prop. 2015, 18, 2009-2014. [CrossRef]

130. Herodež, Š.S.; Hadolin, M.; Škerget, M.; Knez, Ž. Solvent extraction study of antioxidants from Balm (Melissa officinalis L.) leaves. Food Chem. 2003, 80, 275-282. [CrossRef]

131. Wang, H.; Provan, G.J.; Helliwell, K. Determination of rosmarinic acid and caffeic acid in aromatic herbs by HPLC. Food Chem. 2004, 87, 307-311. [CrossRef]

132. Kim, S.; Yun, E.J.; Bak, J.S.; Lee, H.; Lee, S.J.; Kim, C.T.; Lee, J.-H.; Kim, K.H. Response surface optimised extraction and chromatographic purification of rosmarinic acid from Melissa officinalis leaves. Food Chem. 2010, 121, 521-526. [CrossRef]

133. Sik, B.; Hanczné, E.L.; Kapcsándi, V.; Ajtony, Z. Conventional and nonconventional extraction techniques for optimal extraction processes of rosmarinic acid from six Lamiaceae plants as determined by HPLC-DAD measurement. J. Pharm. Biomed. Anal. 2020, 184, 113173. [CrossRef]

134. Angelov, G.; Penchev, P.; Condoret, J.-S. Optimization of operational conditions of ethanol extraction of rosmarinic acid from lemon balm (Melissa officinalis L.). University of Plovdiv "Paisii Hilendarski". Bulg. Sci. Pap. Chem. 2007, 35, 71-76.

135. Caleja, C.; Barros, L.; Prieto, M.A.; Barreiro, M.F.; Oliveira, M.B.P.; Ferreira, I.C. Extraction of rosmarinic acid from Melissa officinalis L. by heat-, microwave- and ultrasound-assisted extraction techniques: A comparative study through response surface analysis. Sep. Purif. Technol. 2017, 186, 297-308. [CrossRef]

136. Binello, A.; Cravotto, G.; Boffa, L.; Stevanato, L.; Bellumori, M.; Innocenti, M.; Mulinacci, N. Efficient and selective green extraction of polyphenols from lemon balm. C. R. Chim. 2017, 20, 921-926. [CrossRef]

137. Radomir, A.M.; Guţă, I.C.; Buciumeanu, E.C.; Pîrvu, M.L. Optimization of microwave extraction method of total polyphenols from Melissa officinalis L. vitroplants. Biologie 2019, 28, 112-118.

138. Tülek, Z.; Alaşalvar, H.; Başyiğit, B.; Berktas, S.; Salum, P.; Erbay, Z.; Telsi, I.; Çam, M. Extraction optimization and microencapsulation of phenolic antioxidant compounds from lemon balm (Melissa officinalis L.): Instant soluble tea production. J. Food Process. Preserv. 2021, 45, e14995. [CrossRef]

139. Ince, A.E.; Şahin, S.; Şümnü, S.G. Extraction of phenolic compounds from melissa using microwave and ultrasound. Turk. J. Agric. For. 2013, 37, 69-75. [CrossRef] 
140. Mabrouki, H.; Duarte, C.M.M.; Akretche, D.E. Estimation of total phenolic contents and in vitro antioxidant and antimicrobial activities of various solvent extracts of Melissa officinalis L. Arab. J. Sci. Eng. 2018, 43, 3349-3357. [CrossRef]

141. Papoti, V.T.; Totomis, N.; Atmatzidou, A.; Zinoviadou, K.; Androulaki, A.; Petridis, D.; Ritzoulis, C. Phytochemical content of Melissa officinalis L. herbal preparations appropriate for consumption. Processes 2019, 7, 88. [CrossRef]

142. Peshev, D.; Peeva, L.G.; Peev, G.; Baptista, I.I.R.; Boam, A.T. Application of organic solvent nanofiltration for concentration of antioxidant extracts of rosemary (Rosmarinus officinallis L.). Chem. Eng. Res. Des. 2011, 89, 318-327. [CrossRef]

143. Komes, D.; Belščak-Cvitanović, A.; Horžić, D.; Rusak, G.; Likić, S.; Berendika, M. Phenolic composition and antioxidant properties of some traditionally used medicinal plants affected by the extraction time and hydrolysis. Phytochem. Anal. 2011, 22, 172-180. [CrossRef]

144. Ribeiro, M.A.; Bernardo-Gil, M.G.; Esquivel, M.M. Melissa officinalis L.: Study of antioxidant activity in supercritical residues. J. Supercrit. Fluids 2001, 21, 51-60. [CrossRef]

145. Nicolai, M.; Pereira, P.; Vitor, R.F.; Reis, C.P.; Roberto, A.; Rijo, P. Antioxidant activity and rosmarinic acid content of ultrasoundassisted ethanolic extracts of medicinal plants. Measurement 2016, 89, 328-332. [CrossRef]

146. Duda, S.C.; Mărghitaş, L.A.; Dezmirean, D.; Duda, M.; Mărgăoan, R.; Bobiş, O. Changes in major bioactive compounds with antioxidant activity of Agastache foeniculum, Lavandula angustifolia, Melissa officinalis and Nepeta cataria: Effect of harvest time and plant species. Ind. Crop. Prod. 2015, 77, 499-507. [CrossRef]

147. Dastmalchi, K.; Dorman, H.D.; Oinonen, P.P.; Darwis, Y.; Laakso, I.; Hiltunen, R. Chemical composition and in vitro antioxidative activity of a lemon balm (Melissa officinalis L.) extract. LWT Food Sci. Technol. 2008, 41, 391-400. [CrossRef]

148. Barnes, J.; Anderson, L.A.; Phillipson, J.D. St John's wort (Hypericum perforatum L.): A review of its chemistry, pharmacology and clinical properties. J. Pharm. Pharmacol 2001, 53, 583-600. [CrossRef]

149. Greeson, J.M.; Sanford, B.; Monti, D.A. St. John's wort (Hypericum perforatum): A review of the current pharmacological, toxicological, and clinical literature. Psychopharmacology 2001, 153, 402-414. [CrossRef]

150. Butterweck, V. Mechanism of action of St John's wort in depressions. What is known? CNS Drugs 2003, 17, 539-562. [CrossRef]

151. Butterweck, V.; Schmidt, M. St. John's wort: Role of active compounds for its mechanism of action and efficacy. Wien. Med. Wochenschr. 2007, 157, 356-361. [CrossRef]

152. Evans, W.C.; Evans, D.; Trease, G.E. Trease and Evans Pharmacognosy, 16th ed.; Saunders/Elsevier: Edinburgh, UK; New York, NY, USA, 2009.

153. Council of Europe. Natural Sources of Flavourings; Report No. 1; Council of Europe: Strasbourg, France, 2000.

154. Beerhues, L. Hyperforin. Phytochemistry 2006, 67, 2201-2207. [CrossRef]

155. von Eggelkraut-Gottanka, S.G.; Abu Abed, S.; Muller, W.; Schmidt, P.C. Quantitative analysis of the active components and the by-products of eight dry extracts of Hypericum perforatum L. (St John's Wort). Phytochem. Anal. 2002, 13, 170-176. [CrossRef]

156. Poutaraud, A.; Di Gregorio, F.; Chan, F.; Tin, V.; Girardin, P. Effect of light on hypericins contents in fresh flowering top parts and in an extract of St. John's wort (Hypericum perforatum). Planta Med. 2001, 67, 254-259. [CrossRef]

157. Avato, P.; Guglielmi, G. Determination of major constituents in St. John's wort under different extraction conditions. Pharm. Biol. 2004, 42, 83-89. [CrossRef]

158. Smelcerovic, A.; Spiteller, M.; Zuehlke, S. Comparison of methods for the exhaustive extraction of hypericins, flavonoids, and hyperforin from Hypericum perforatum L. J. Agric. Food Chem. 2006, 54, 2750-2753. [CrossRef]

159. Zeliou, K.; Koui, E.-M.; Papaioannou, C.; Koulakiotis, N.S.; Iatrou, G.; Tsarbopoulos, A.; Papasotiropoulos, V.; Lamari, F.N. Metabolomic fingerprinting and genetic discrimination of four Hypericum taxa from Greece. Phytochemistry 2020, $174,112290$. [CrossRef]

160. Milevskaya, V.V.; Statkus, M.A.; Temerdashev, Z.A.; Kiseleva, N.V.; Butyl'skaya, T.S.; Shil'ko, E.A. Extraction and determination of biologically active components of St. John's wort and its pharmaceutical preparations. J. Anal. Chem. 2016, 71, 741-747. [CrossRef]

161. Williams, F.B.; Sander, L.C.; Wise, S.A.; Girard, J. Development and evaluation of methods for determination of naphthodianthrones and flavonoids in St. John's wort. J. Chromatogr. A 2006, 1115, 93-102. [CrossRef]

162. Cervo, L.; Rozio, M.; Ekalle-Soppo, C.B.; Guiso, G.; Morazzoni, P.; Caccia, S. Role of hyperforin in the antidepressant-like activity of Hypericum perforatum extracts. Psychopharmacology 2002, 164, 423-428. [CrossRef]

163. Cui, Y.; Ang, C.Y. Supercritical fluid extraction and high-performance liquid chromatographic determination of phloroglucinols in St. John's Wort (Hypericum perforatum L.). J. Agric. Food Chem. 2002, 50, 2755-2759. [CrossRef]

164. Gaid, M.; Haas, P.; Beuerle, T.; Scholl, S.; Beerhues, L. Hyperforin production in Hypericum perforatum root cultures. J. Biotechnol. 2016, 222, 47-55. [CrossRef]

165. Orth, H.C.J.; Rentel, C.; Schmidt, P.C. Isolation, purity analysis and stability of hyperforin as a standard material from Hypericum perforatum L. J. Pharm. Pharmacol. 1999, 51, 193-200. [CrossRef]

166. Cossuta, D.; Vatai, T.; Báthori, M.; Hohmann, J.; Keve, T.; Simándi, B. Extraction of hyperforin and hypericin from St. John's wort (Hypericum perforatum L.) with different solvents. J. Food Process. Eng. 2009, 35, 222-235. [CrossRef]

167. Poutaraud, A.; Lobstein, A.; Girardin, P.; Weniger, B. Improved procedure for the quality control of Hypericum perforatum L. Phytochem. Anal. 2001, 12, 355-362. [CrossRef]

168. Wölfle, U.; Seelinger, G.; Schempp, C.M. Topical application of St. John's Wort (Hypericum perforatum). Planta Med. 2014, 80, 109-120. [CrossRef] 
169. Catchpole, O.J.; Perry, N.B.; Da Silva, B.M.T.; Grey, J.B.; Smallfield, B.M. Supercritical extraction of herbs I: Saw Palmetto, St John's wort, Kava root, and Echinacea. J. Supercrit. Fluids 2002, 22, 129-138. [CrossRef]

170. Glisic, S.; Smelcerovic, A.; Zuehlke, S.; Spiteller, M.; Skala, D. Extraction of hyperforin and adhyperforin from St. John's Wort (Hypericum perforatum L.) by supercritical carbon dioxide. J. Supercrit. Fluids 2008, 45, 332-337. [CrossRef]

171. Mannila, M.; Kim, H.; Isaacson, C.; Wai, C.M. Optimization of supercritical fluid extraction for the separation of hyperforin and adhyperforin in St. John's wort (Hypericum perforatum L.). Green Chem. 2002, 4, 331-336. [CrossRef]

172. Liu, F.F.; Ang, C.Y.W.; Springer, D. Optimization of extraction conditions for active components in Hypericum perforatum using response surface methodology. J. Agric. Food Chem. 2000, 48, 3364-3371. [CrossRef] [PubMed]

173. Pradeep, M.; Kachlicki, P.; Franklin, G. Simultaneous determination of naphtodianthrones, emodin, skyrin and new bisanthrones in Hypericum perforatum L. in vitro shoot cultures. Ind. Crop. Prod. 2020, 144, 112003. [CrossRef]

174. Karioti, A.; Bilia, A.R. Hypericins as potential leads for new therapeutics. Int. J. Mol. Sci. 2010, 11, 562-594. [CrossRef]

175. Smelcerovic, A.; Laatsch, H.; Lepojevic, Z.; Djordjevic, S. The separation of hypericin and pseudohypericin from Hypericum perforatum L. Pharmazie 2002, 57, 178-180.

176. Aybastier, O.; Sahin, S.; Demir, C. Response surface optimized ultrasonic-assisted extraction of quercetin and isolation of phenolic compounds from Hypericum perforatum L. by column chromatography. Sep. Sci. Technol. 2013, 48, 1665-1674. [CrossRef]

177. Karakashov, B.; Grigorakis, S.; Loupassaki, S.; Makris, D.P. Optimisation of polyphenol extraction from Hypericum perforatum (St. John's Wort) using aqueous glycerol and response surface methodology. J. Appl. Res. Med. Aromat. Plants 2015, 2, 1-8. [CrossRef]

178. Orčić, D.Z.; Mimica-Dukić, N.M.; Francišković, M.M.; Petrović, S.S.; Jovin, E.Đ. Antioxidant activity relationship of phenolic compounds in Hypericum perforatum L. Chem. Cent. J. 2011, 5, 1-8. [CrossRef]

179. Kalogeropoulos, N.; Yannakopoulou, K.; Gioxari, A.; Chiou, A.; Makris, D.P. Polyphenol characterization and encapsulation in b-cyclodextrin of a flavonoid-rich Hypericum perforatum (St Johns wort) extract. Lebensm. Wiss. Technol. Food Sci. Technol. 2010, 4 882-889. [CrossRef]

180. Silva, B.A.; Malva, J.O.; Dias, A.C.P. St. John's wort (Hypericum perforatum) extracts and isolated phenolic compounds are effective antioxidants in several in vitro models of oxidative stress. Food Chem. 2008, 110, 611-619. [CrossRef]

181. Hernandez, M.F.; Fale, P.L.V.; Araujo, M.E.M.; Serralheiro, M.L.M. Acetylcholinesterase inhibition and antioxidant activity of the water extracts of several Hypericum species. Food Chem. 2010, 120, 1076-1082. [CrossRef]

182. Nemati, Z.; Harpke, D.; Gemicioglu, A.; Kerndorff, H.; Blattner, F.R. Saffron (Crocus sativus) is an autotriploid that evolved in Attica (Greece) from wild Crocus cartwrightianus. Mol. Phylogenet. Evol. 2019, 136, 14-20. [CrossRef]

183. Pandita, D. Saffron (Crocus sativus L.): Phytochemistry, therapeutic significance and omics-based biology. In Medicinal and Aromatic Plants. Expanding Their Horizons through Omics; Aftab, T., Hakeem, K.R., Eds.; Academic Press: Cambridge, MA, USA, 2021; Chapter 14; pp. 325-396. ISBN 978-0-12-819590-1.

184. Siracusa, L.; Gresta, F.; Ruberto, G. Saffron (Crocus sativus L.) apocarotenoids: A review of their biomolecular features and biological activity perspectives. In Carotenoids: Properties, Effects and Diseases; Yamaguchi, M., Ed.; Nova Science Publishers: Hauppauge, NY, USA, 2011; pp. 145-178. ISBN 978-1-61209-713-8.

185. Koulakiotis, N.S.; Gikas, E.; Iatrou, G.; Lamari, F.N.; Tsarbopoulos, A. Quantitation of Crocins and Picrocrocin in Saffron by HPLC: Application to Quality Control and Phytochemical Differentiation from Other Crocus Taxa. Planta Med. 2015, 81, 606-612. [CrossRef]

186. Tarantilis, P.A.; Tsoupras, G.; Polissiou, M. Determination of saffron (Crocus sativus L.) components in crude plant extract using high-performance liquid chromatography-UV-visible photodiode-array detection-mass spectrometry. J. Chromatogr. A 1995, 699, 107-118. [CrossRef]

187. Carmona, M.; Zalacain, A.; Sánchez, A.M.; Novella, J.L.; Alonso, G.L. Crocetin Esters, Picrocrocin and Its Related Compounds Present in Crocus sativus Stigmas and Gardenia jasminoides Fruits. Tentative Identification of Seven New Compounds by LC-ESI-MS. J. Agric. Food Chem. 2006, 54, 973-979. [CrossRef] [PubMed]

188. Roshanravan, B.; Samarghandian, S.; Ashrafizadeh, M.; Saeedi, F.; Farkhondeh, T. Metabolic impact of saffron and crocin: An updated systematic and meta-analysis of randomised clinical trials. Arch. Physiol. Biochem. 2020, 1-13. [CrossRef]

189. Lambrianidou, A.; Koutsougianni, F.; Papapostolou, I.; Dimas, K. Recent Advances on the Anticancer Properties of Saffron (Crocus sativus L.) and Its Major Constituents. Molecules 2021, 26, 86. [CrossRef]

190. Kazemi, F.; Vosough, I.; Sepahi, S.; Ahmad, S. Effect of crocin versus fluoxetine in treatment of mild to moderate obsessive compulsive disorder: A double blind randomized clinical trial. Hum. Psychopharmacol. Clin. Exp. 2021. [CrossRef]

191. Lopresti, A.L.; Smith, S.J.; Metse, A.P.; Drummond, P.D. Effects of saffron on sleep quality in healthy adults with self-reported poor sleep: A randomized, double-blind, placebo-controlled trial. J. Clin. Sleep Med. 2020, 16, 937-947. [CrossRef]

192. Kyriakoudi, A.; Tsimidou, M.Z. Latest advances in the extraction and determination of saffron apocarotenoids. Electrophoresis 2018, 39, 1846-1859. [CrossRef]

193. Rajabzadeh, Q.; Malekzadeh, R.; Sharif, A. Extraction and Evaluation of Saffron Oleoresin. Acta Hortic. 2004, 650, 361-364. [CrossRef]

194. Montalvo-Hernández, B.; Rito-Palomares, M.; Benavides, J. Recovery of crocins from saffron stigmas (Crocus sativus) in aqueous two-phase systems. J. Chromatogr. A 2012, 1236, 7-15. [CrossRef]

195. Sani, A.M.; Mohseni, S. Effect of type and concentration of solvent on chemical properties of saffron edible extract. Nutr. Food Sci. 2013, 44, 2-5. [CrossRef] 
196. Gallo, M.; Ferracane, R.; Graziani, G.; Ritieni, A.; Fogliano, V. Microwave Assisted Extraction of Phenolic Compounds from Four Different Spices. Molecules 2010, 15, 6365-6374. [CrossRef]

197. Kyriakoudi, A.; Tsimidou, M.Z. A Food-Grade Approach to Isolate Crocetin from Saffron (Crocus sativus L.) Extracts. Food Anal. Methods 2015, 8, 2261-2272. [CrossRef]

198. Gazeran, S.; Tajalli, F.; Sani, A.M. Effect of Ultrasonic Extraction on Qualitative Parameters of Saffron Edible Extract. J. Essent. Oil Bear. Plants 2016, 19, 1286-1291. [CrossRef]

199. Shinwari, K.J.; Rao, P.S. Thermal-Assisted high hydrostatic pressure extraction of nutraceuticals from saffron (Crocus sativus): Process optimization and cytotoxicity evaluation against cancer cells. Innov. Food Sci. Emerg. Technol. 2018, 48, 296-303. [CrossRef]

200. Lozano, P.; Delgado, D.; Gomez, D.; Rubio, M.; Iborra, J.L. A non-destructive method to determine the safranal content of saffron (Crocus sativus L.) by supercritical carbon dioxide extraction combined with high-performance liquid chromatography and gas chromatography. J. Biochem. Biophys. Methods 2000, 43, 367-378. [CrossRef]

201. Shao, Q.; Huang, Y.; Zhou, A.; Guo, H.; Wang, Y. Application of response surface methodology to optimise supercritical carbon dioxide extraction of volatile compounds from Crocus sativus. J. Sci. Food Agric. 2013, 94, 1430-1436. [CrossRef]

202. Goleroudbary, M.G.; Ghoreishi, S.M. Response surface optimization of Safranal and Crocin extraction from Crocus sativus L. via supercritical fluid technology. J. Supercrit. Fluids 2016, 108, 136-144. [CrossRef]

203. Nerome, H.; Ito, M.; Machmudah, S.; Kanda, H. Extraction of phytochemicals from saffron by supercritical carbon dioxide with water and methanol as entrainer. J. Supercrit. Fluids 2016, 107, 377-383. [CrossRef]

204. Caser, M.; Demasi, S.; Stelluti, S.; Donno, D.; Scariot, V. Crocus sativus L. Cultivation in alpine environments: Stigmas and tepals as source of Bioactive Compounds. Agronomy 2020, 10, 1473. [CrossRef]

205. Termentzi, A.; Kokkalou, E. LC-DAD-MS (ESI+) Analysis and Antioxidant Capacity of Crocus sativus Petal Extracts. Planta Med. 2008, 74, 573-581. [CrossRef]

206. Goupy, P.; Abert, M.; Chemat, F.; Caris-Veyrat, C. Identification and quantification of flavonols, anthocyanins and lutein diesters in tepals of Crocus sativus by ultra performance liquid chromatography coupled to diode array and ion trap mass spectrometry detections. Ind. Crop. Prod. 2013, 44, 496-510. [CrossRef]

207. Stelluti, S.; Caser, M.; Demasi, S.; Scariot, V. Sustainable Processing of Floral Bio-Residues of Saffron (Crocus sativus L.) for Valuable Biorefinery Products. Plants 2021, 10, 523. [CrossRef]

208. Ahmadian-Kouchaksaraie, Z.; Niazmand, R.; Najafi, M.N. Optimization of the subcritical water extraction of phenolic antioxidants from Crocus sativus petals of saffron industry residues: Box-Behnken design and principal component analysis. Innov. Food Sci. Emerg. Technol. 2016, 36, 234-244. [CrossRef]

209. Khazaei, K.M.; Jafari, S.M.; Ghorbani, M.; Kakhki, A.H.; Sarfarazi, M. Optimization of Anthocyanin Extraction from Saffron Petals with Response Surface Methodology. Food Anal. Methods 2016, 9, 1993-2001. [CrossRef]

210. Ahmadian-Kouchaksaraie, Z.; Niazmand, R. Supercritical carbon dioxide extraction of antioxidants from Crocus sativus petals of saffron industry residues: Optimization using response surface methodology. J. Supercrit. Fluids 2017, 121, 19-31. [CrossRef]

211. Da Porto, C.; Natolino, A. Extraction kinetic modelling of total polyphenols and total anthocyanins from saffron floral bio-residues: Comparison of extraction methods. Food Chem. 2018, 258, 137-143. [CrossRef] [PubMed]

212. Jafari, S.M.; Mahdavee Khazaei, K.; Assadpour, E. Production of a natural color through microwave-assisted extraction of saffron tepal's anthocyanins. Food Sci. Nutr. 2019, 7, 1438-1445. [CrossRef] [PubMed]

213. Hashemi, H.; Parastouei, K.; Mokhtarian, M.; Rostami, H.; Niakousari, M.; Mohsenpour, Z. Application of innovative processing methods for the extraction of bioactive compounds from saffron (Crocus sativus) petals. J. Appl. Res. Med. Aromat. Plants 2020, 19, 100264. [CrossRef]

214. Assimopoulou, A.N.; Sinakos, Z.; Papageorgiou, V.P. Radical scavenging activity of Crocus sativus L. extract and its bioactive constituents. Phytother. Res. 2005, 19, 997-1000. [CrossRef]

215. Tsimogiannis, D.I.; Oreopoulou, V. The contribution of flavonoid C-ring on the DPPH free radical scavenging efficiency. A kinetic approach for the $3^{\prime}, 4^{\prime}$-hydroxy substituted members. Innov. Food Sci. Emerg. Technol. 2006, 7, 140-146. [CrossRef]

216. Tsimogiannis, D.; Bimpilas, A.; Oreopoulou, V. DPPH radical scavenging and mixture effects of plant o-diphenols and essential oil constituents. Eur. J. Lipid Sci. Technol. 2017, 119, 16003473. [CrossRef]

217. Dar, R.A.; Brahman, P.K.; Khurana, N.; Wagay, J.A.; Lone, Z.A.; Ganaie, M.A.; Pitre, K.S. Evaluation of antioxidant activity of crocin, podophyllotoxin and kaempferol by chemical, biochemical and electrochemical assays. Arab. J. Chem. 2017, 10, S1119-S1128. [CrossRef]

218. Rajabi, H.; Ghorbani, M.; Mahdi, S.; Sadeghi, A.; Rajabzadeh, G. Retention of saffron bioactive components by spray drying encapsulation using maltodextrin, gum Arabic and gelatin as wall materials. Food Hydrocoll. 2015, 51, 327-337. [CrossRef]

219. Karasu, S.; Bayram, Y.; Ozkan, K.; Sagdic, O. Extraction optimization crocin pigments of saffron (Crocus sativus) using response surface methodology and determination stability of crocin microcapsules. J. Food Meas. Charact. 2019, 13, 1515-1523. [CrossRef]

220. Gani, A.; Jan, R.; Ashwar, B.A.; Ashraf, Z.; Shah, A.; Gani, A. Encapsulation of saffron and sea buckthorn bioactives: Its utilization for development of low glycemic baked product for growing diabetic population of the world. LWT 2021, 142, 111035. [CrossRef] 